\title{
SoM Krisztián \\ Határforgalom ellenőrzés és a külföldre utazás szabályozása Magyarországon az I. világháborúban
}

A dualizmuskori békeévekben törvény biztosította a határátlépés útlevélmentességét. Mindenki számára biztosított jog volt, hogy szabadon oda utazhatott ahová akart. Ehhez foganatosítottak csupán szükítő korlátozásokat a jogerősen elítéltek, a katonai szolgálatot teljesítők számára. A törvény felhatalmazta továbbá a belügyminisztert arra, hogy útlevél kötelezettséget állapítson meg azon országok polgárai számára, amelyek a Magyar Királyság állampolgárai számára útlevelet írtak elő az országukba való belépéshez. ${ }^{1}$

A törvény szellemisségét követték a magyar határforgalom-ellenőrzés szabályozó rendelkezések is. A szabályozásokban szerepelt, hogy a határátkelőhelyek személyzetének háza-népe a túloldali legközelebbi településre útiokmány nélkül átléphette a határt. Ugyanez vonatkozott a határátkelőhely melletti település lakóira is, ha személyük ismert volt az útlevélkezelők elött. Azokat a személyeket is át kellett léptetni a határon, akik otthon felejtették ugyan az útlevelüket, de az útlevélkezelök ismerték őket és tudták, hogy van útlevelük. ${ }^{2}$

Az útlevélhez, vagy a kishatárforgalmi úti okmányhoz való hozzáférés is egyszerü volt és bárkinek - a minimális kizáró okok kivételével — állampolgári jogon járt. Kishatárforgalmi okmányt a határvonaltól számított $40 \mathrm{~km}$ széles határsávban lehetett igényelni a határ mindkét oldalán. A hatóságok ezt az úti okmányt mindenkinek kiállították akkor is ha nem ezen a területen lakott. Ezzel az úti okmánnyal pedig a határ túloldalán ugyancsak $40 \mathrm{~km}$-es sávban lehetett közlekedni bár a határ egyik oldalán sem ellenőrizték ennek a betartását. A határon átnyúló birtokkal rendelkezőknek pedig még erre az úti okmányra sem volt szükségük — ha a birtokuk területéról a túloldalon nem kívántak kilépni — mivel a birtokuk területén bárhol átléphették a határt. ${ }^{3}$

A határforgalom szellemisége azonban a I. világháború során 180 fokos fordulatot vett. A változás elöjelei már a háború kirobbanása előtt is érezhetőek voltak. Sajnálatos módon a háború befejeződése után sem álltak helyre a harcokat megelőző békeidőszak viszonyai. A háborús időszak rigorózus szabályai — több-kevesebb változtatással - lényegében a rendszerváltásig fennmaradtak. Azonban a rendszerváltással létrejövő enyhülés sem eredményezte azt a szabadságot, amit elődeink már a dualizmus időszakában éveztek. ${ }^{4}$

A határforgalom-ellenőrzés és az idegenrendészet szigorítását már több szabályozás is elörevetítette az I. világháborút közvetlenül megelőző időszakban. ${ }^{5}$

A határforgalom-ellenőrzés várható szigorítása azonban csak részét képezte a katonai határőrizetre való áttérésnek, amelyre a felkészülést már 1912-ben elkezdték. A területileg illetékes hadtest-parancsnokságok vezérkari osztályain dolgozták ki a katonai határőrizetre való áttérés terveit, melyeket a határőrizetben résztvevő rendvédelmi testületek helyi képviselöivel a helyszínen egyeztettek és pontosítottak. A katonai határőrizetre való áttérés terveit a Magyar Királyság határszakaszai közül csak a magyar-román és a magyar-szerb határra dolgozták ki és készítették elő, mivel itt volt várható harctevékenység fegyveres konfliktus esetén. ${ }^{6}$

A határforgalom-ellenőrzés és a külföldre utazás szabályainak szigorítása a kivételes hatalom intézkedéseinek a végrehajtására vonatkozó rendeletek sorába illeszkedtek. A XX. század elején Euró-pa nagyhatalmai háborúra készülődtek. Valamennyien arra számítottak, hogy személyi és anyagi eröforrásaikat maximálisan igénybe kell venniük a győzelem érdekében. Ebből fakadóan jogi úton is szabályozni kívánták forrásaik akadálytalan igénybevételét, ennek érdekében pedig az általános polgári és emberi jogokat is korlátozni kívánták. A magyar terminológiában e jogi szabályokat nevezték a kivételes hatalom gyakorlása érdekében létrehozott jogszabályoknak. Alapvetően kétféle útja alakult ki a kivételes hatalom szabályozásának. Az angolszász minta szerint a kivételes hatalom jogosultságaival a kormány élhetett, míg a német minta szerint a kivételes hatalmat a haderőre ruházták. Az Osztrák-Magyar Monarchia két társországában a kivételes hatalom szabályozásának kétféle megoldását alkalmazták. Az Osztrák Császárságban a német mintát, a Magyar Királyságban pedig a brit mintát követték. Magyarországon viszonylag későn — a közös haderő többszöri sürgetése nyomán — 1912-ben szabályozták a témakört. Az osztrák és a magyar kivételes hatalomra vonatkozó törvényekben egyaránt a hadmüveleti területeken a hatalmat a haderö gyakorolta. Ebböl a helyzetből fakadóan a külföldre utazás és a határforgalom, valamint a hadmüveleti záróvonal átlépésének tekintetében a polgári közigazgatás és a haderő illetékeseinek nyilvánvalóan egyeztetniük kellett az egységes elvek és végrehajtás érdekében. Ezek az egyeztetések minden bizonnyal létrejöttek és eredményesek voltak, 
amelyek a vonatkozó rendeletek szövegéből kideríthetőek. Mindehhez azonban az alapot a két ország kivételes hatalomról szóló törvényei biztosították. ${ }^{7}$

A határforgalom-ellenőrzés mindenkori célja a határon átkelő személyek, poggyászaik és egyéb, kereskedelmi áruk ellenőrzése volt, biztonsági illetve vámügyi szempontok szerint, ami kiegészült az állatok, illetve a feldolgozott termékek egészségügyi vizsgálatával is. A személyforgalom felügyelete az utiokmányok ellenőrzésének a segítségével valósult meg. Az ellenőrzés célját a közbiztonságra veszélyes vagy büncselekményt, kihágást elkövetők felfedése, valamint a külföldiekkel szembeni esetleges idegenrendészeti eljárások megalapozása alkotta.

A határforgalom ellenőrzése, a külföldre utazás szabályai és az idegenrendészet párhuzamosan és részben összefonódva fejlődött a béke és háború időszakában egyaránt. A háború idején egyre összetettebbé váló határforgalom-ellenőrzés megértéséhez szükséges az 1914. év nyara előtti időszak ellenőrzése tartalmának megismerése.

\section{A Magyar Királyság határforgalma a dualizmus békeidőszakában}

Magyarország „,külső”, azaz az Osztrák Császársággal nem közös határszakaszán útlevél-kötelezettség állt fenn — amely alól a szerbiai viszonylat 1910. és 1912. között volt mentes —, ennek megfelelően a magyar-szerb és a magyar-román államhatárt csak a kijelölt határátkelőhelyeken lehetett átlépni a megfelelő úti okmány birtokában, bár a kishatárforgalom tekintetében ez erős enyhítésekkel valósult meg. A kikötőkben - elsősorban a jelentősebb nemzetközi kapcsolatokkal rendelkező fiumeiben függetlenül a hajók által érintett kikötőktől és a végcéljuktól csak a kivándorlók ellenőrzése folyt. ${ }^{8} \mathrm{Az}$ Osztrák-Magyar Monarchiának azon „külső” határain, ${ }^{9}$ ahol útlevél-kötelezettség nem állt fenn — a személyforgalom ellenőrzése sem valósulhatott meg — vámellenőrzés azonban volt. ${ }^{\mathbf{1 0}}$

A magyar-román és a magyar-szerb határon csaknem 30 településen müködött határátkelőhely, korabeli szóhasználat szerint határkapu. ${ }^{11}$ (I.sz. melléklet)

A közúti határátkelöhelyeket elsősorban a határhoz közeli járások és vármegyék lakosai használták. Jelentôs volt egyes határátkelőhelyeken - ahol közel volt mindkét oldalon egy-egy nagyobb település - a gyalogos forgalom, illetve általánosságban az állat vontatta fogatok átlépése. Mindezek mellett gépkocsik is előfordultak, bár a vidéki utántöltésük illetve javíttatásuk ekkor még nehézségekbe ütközött, ráadásul a vételáruk is legfeljebb a tehetősebb középrétegek számára volt elérhető. A menetrend szerinti autóbusz-forgalom az Osztrák-Magyar Monarchiában elsősorban az osztrák örökös tartományokban volt számottevö, de ott is csak helyközi viszonylatban. ${ }^{12}$

A vasút nyújtotta a nagyobb szárazföldi távolságra, így külföldre is az általános közlekedési lehetőséget. A vasút az 1910-es évek legelején élte a fénykorát. A korábbi évtizedekhez képest a jegyárak csökkentek, a szerteágazó hálózat miatt sokan vették igénybe. A gyorsvonati szerelvényeket vontató mozdonyok végsebessége már ekkor meghaladta akár a $100 \mathrm{~km} /$ órát. A nemzetközi vasúti forgalom élénk volt, nemcsak Európa nyugatabbra eső városaiba, hanem délkeletre is. A Magyar Szent Korona országait is érintő vasúti forgalomban - hasonlóan az Osztrák Császárság és a többi európai ország vasúti forgalmához - mindhárom kényelmi osztály kocsija futott. Szerbiába és Romániába menetrend szerint indultak nemzetközi gyorsvonatok. ${ }^{13}$

A magyar és a román főváros között naponta öt alkalommal oda és ötször vissza indultak vasúti személyszállító szerelvények. ${ }^{14}$

A Magyar Királyi Államvasutak és a vele együttmüködő európai vasúti társaságok 1906-tól már napi rendszerességgel müködtették a csak első osztályú kocsikból álló Orient Expresszt. ${ }^{15}$ A közel 3100 km-es, PárizsKonstantinápoly útvonalat 1914. nyarán a szerelvények már csak 61 óra 46 perc alatt tették meg, ami 50,2 km/órás átlagsebességet jelentett. ${ }^{16}$ Az Orient Express magas viteldíja miatt elsősorban gazdagok és előkelő személyek vehették igénybe, valamint az uralkodói családok tagjai Európából és még Ázsiából is. A két végállomás között utazók összesen 6 esetben estek át útlevélellenőrzésen, a Párizsból vagy Berlinből indulók úti okmányait először a magyar határrendőrök ellenörizték Zimonynál, illetve a keletről érkezőekét ugyanitt utoljára.

A hajó olcsó, de egyben lassú is volt, valamint Magyarországon meglehetősen korlátozott menetvonalon lehetett igénybe venni, mivel forgalmuk elsősorban a nagyobb folyamokon zajlott, illet-ve az Adria parti kikötők között. A Duna magyarországi alsóbb szakaszán — a teherszállítás mellett — számottevő utasforgalom valósult meg sőt, Orsovából lehetőség nyílt az Al-Duna irányába is menetrend szerint utazni. Fiume volt Magyarország legforgalmasabb tengeri kikötője, bár szerepe az osztrák Trieszt mellett kisebb volt, azonban a fejlesztéseket és a vasúti kapcsolatának a követően mind gyakrabban érkeztek ide hajók Ázsiából és Amerikából is. 
A légi közlekedésnek Közép-Európában nem volt lényegi célja a határon át történő utazás, bár elvétve előfordulhatott. Így az 1905-ös határrendőri utasítás is rendelkezett a külföldröl „léghajóval” határt átlépő polgári személyek ellenőrzésének céljáról és módjáról is. ${ }^{17} \mathrm{Az}$ alig két éve megvalósult, levegőnél nehezebb szerkezet motoros repülése, akkor még kis távolságra és elvétve fordult elö. A gázés hőlégballonok olcsóbb eszközök voltak ugyan, de repülési irányuk csak tervezhető volt, a menetterv megvalósítása az eltérő magasságokban uralkodó széljárásoktól függött. Ezért már a XX. század első másfél évtizedében is elsősorban kedvtelési és kikötött változatait katonai célokra alkal-mazták. A levegőnél könnyebb, motor hajtotta léghajók a századfordulót követően gyors ütemben fej-lődtek. A léghajókon megvalósuló alkalmi távolsági utazás 1910-es évektől már szélesebb körben is elérhető volt. ${ }^{18}$ A motoros repülést - kifejlődésének éveit követően is - a kísérletező kedvü fej-lesztők, a repülésre vágyó tehetősebbek és természetesen a haderők hasznosították. Az első keres-kedelmi célú, menetrend szerinti személyszállító légi járat már 1914. I. 1-jén indult az Amerikai Egy-esült Államokban. ${ }^{19}$ A számottevő polgári légi személyszállítás lehetősége — igaz egyelőre csak or-szághatáron belüli forgalomban és csak két országban - már megvalósult 1914. nyarára.

Változások a magyar állampolgárok külföldre utazásában a Balkán-háborúk (1912-1913) idején. Az első Balkán-háború kitörése (1912. X. 9.) és a kiterjedő hadmüveletek, valamint a már korábbi években is egyre nagyobb arányban kivándorló magyar védkötelesek miatt, a magyar miniszterelnök, az ő távozásukat kivándorlási célzattal 1912. XII. 6-án egy évre megtiltotta, egyúttal a fegyveres erők kötelékébe tartozók útleveleinek kiadását is ideiglenesen beszüntette. ${ }^{20} \mathrm{Az}$ érintett személyeknek korábban kiadott úti okmányokat a törvényhatóságoknak be kellett vonniuk. Budapesten az - átutazókat is figyelemmel kísérő - vasúti rendőr-kirendeltségek által igazoltatott és az említett személyeknél talált útlevelek bevonásáról a budapesti főkapitány 1912. XII. 10-én intézkedett. ${ }^{21}$ Bár az Osztrák-Magyar Monarchia mindkét Balkán-háborúban semleges maradt, azonban a feszültség miatt a korlátozásokat csak egy évvel később - a hadat viselő felek által Bukarestben megkötött békeszerződést követő negyedik hónapban - oldották fel. ${ }^{22}$

\section{A határforgalmat ellenőrző hatóságok 1914. év nyaráig}

A kiegyezéstől, valamint a katonai határőrvidék felszámolását követően, az útlevél-ellenőrzés mindenhol az átkelőhely elhelyezkedése szerint illetékes törvényhatóság feladata volt. A határátkelőhelyeken a rendőrbiztosi hivatal személyi állományán kívül a vámhivatalok és az egészségügyi állomás (vesztegintézet) személyzete látott el állandó szolgálatot. A határvonal örzését a pénzügyőr járőrök, majd 1891-től a csendőrség határszéli őrsei látták el. ${ }^{23}$ Ebben egészen 1906-ig nem volt jelentősebb változás.

1903-ban ezen változtatott a magyar országgyülés, amikor törvényt alkotott a Magyar Királyi Határrendőrség felállításáról. Az új állami rendőrséget számos feladat végrehajtásával bízta meg a jogszabály, így többek között ,azon határvonalon, hol útlevél-kötelezettség áll fenn, az útlevelek vizsgálata, ... kitiltott, rendőri kifogás alá eső és magukat igazolni nem tudó egyének az állam területére belépésben megakadályozása, . . . nyomozott, vagy valamely büntető cselekménnyel gyanúsított $\mathrm{s}$ a törvények vagy a fennálló szabályok értelmében előzetesen letartóztatható egyéneknek a határszélen való letartóztatása, . . . nőcsempészet meggátlása . . . határszéli vasúti és gőzhajó állomásokon az államrendőri és közbiztonsági teendők ellátása $\mathrm{s}$ a közegészségügyi szabályok betartásának ellenőrzése" ${ }^{24}$ A magyar miniszterelnök és belügyminiszter ezt követően rendeletek útján szabályozta a leendö határrendőrség müködését és viszonyát más hatóságokhoz. A határforgalom ellenőrzését ténylegesen csak 1906. I. 15-től látta el a Magyar Királyi Határrendőrség. Feladatát a vámhivatalok és az állategészségügyi hatóságok mellett hajtotta végre, esetenként más, az államhatár biztonságában érdekelt szervezetek bevonásával. ${ }^{25}$ Amennyiben a határrendőrség határforgalom-ellenőrzés végrehajtására rendelt közegei nem bizonyultak elegendőnek a határátkelőhely müködtetése vagy, meghatározott feladat teljesítésére, akkor a helyi rendőrség vagy a csendőrség támogatta a testületet. Ilyen támogatás lehetett a határátkelőhely rendjének betartatása érdekében karhatalom bizto-sítása, megfigyelésben és „,nyomozási cselekmény végrehajtása körüli segédkezésben" való részvé-tel. ${ }^{26}$ Így a határrendőrség helyi szervezetei lényegében az egyes határőrizeti tevékenységek végre-hajtásának összefogását, irányítását látták el.

A Magyar Királyi Határrendörség kapitányságokon, azon belül felállított kirendeltségeken keresztül látta el feladatait, illetve 1908 és 1912 között tovább tagozódott őrsökre is. A határrendörség területi szervezetei még a magyar-horvát határszakaszon áthaladó vasútvonalak utolsó magyarországi állomásain is folytatták az engedély, azaz útlevél nélkül kivándorlók kiszürésére irányuló ellenőrzést.

A határforgalom-ellenőrző hatóságok terén 1912 tavaszán ismét jelentős változás állt be. A szerb és a román viszonylat mentén müködő legtöbb határátkelőhelyen — ott ahol a határforgalom döntö többségét a kishatárforgalom alkotta — a határrendör kirendeltségek illetékességéből kivették az úti 
okmányok ellenőrzését, és azokon a helyeken a Magyar Királyi Csendőrség hatáskörébe utalták. A csendőrség az általa átvett útlevél-ellenőrző feladatokat a „határkapu”-hoz kihelyezett, határforgalomellenőrző személyi állomány útján végezte. ${ }^{27}$ A határrendőr kirendeltségek és kapitányságok $1912 . \mathrm{V}$. 1-je után, a Romániával közös határszakaszon már csak a vasúti határátkelőhelyeken folytattak útlevél-ellenőrzést, azaz Vöröstoronyban, Predeálban, Gyimesbükkben, valamint Orsova vasúti és vízi határállomásain. Ezen átkelőhelyeken a közúti forgalom ellenőrzése szintén a csendőrség feladatává vált. ${ }^{28}$ A vasút által szállított jelentős személyforgalom miatt azonban a határrendőrség továbbra is jelentős számú utasforgalom ellenőrzését látta el. A legnagyobb magyar kikötővárosban, Fiumében a kivándorlókra kiterjesztett útlevélellenőrzés feladatát a fiumei városi rendőrhatóság, majd - 1913 nyarától az akkor felállított — fiumei határrendőr kapitányság beosztottjai valósították meg. ${ }^{29}$

A határrendőrség létszáma 1914-re elérte a 451 föt. E létszámba tartozott a 17-re növekedett kapitánysági és a 41-re emelkedett kirendeltségi és kiszolgáló személyzet is. A Magyar Királyi Határrendőrség személyi állományának egy része az osztrák örökös tartományokkal határos útvonalak mentén teljesített szolgálatot. ${ }^{30} \mathrm{~A}$ csendőrség határszéli szolgálatát a magyar-szerb viszonylatban 52 őrsön szolgálatot teljesítő 310 csendőrrel látta el, míg a lényegesen hosszabb magyar-román határ-szakaszt 107 őrs 728 csendőrével ellenőrizték 1912 után. A határátkelőhelyeken szolgálatot ellátó fegyveres testületek tagjai mellett még a vámhivatalok és az egészségügyi állomások személyzete, összességében mintegy 300-400 fö körül mozgó létszámmal látott el szolgálatot. ${ }^{31}$

\section{A határforgalom ellenőrzésének végrehajtása Magyarországon, 1906-tól}

Az Osztrák-Magyar Monarchia Magyar Királyságának csak a szerbiai és a romániai határszakaszán volt útlevélkényszer és egyúttal állandó határforgalom-ellenőrzés is. Az Osztrák Császárság a román, illetve az orosz viszonylatban ellenőrizte az utasforgalmat Az Oroszországból érkezőkkel szemben a viszonosság elvén — általános láttamozási (vízum-) kényszer is fennállt. Az Osztrák Császárság Németországgal, Svájccal és Olaszországgal, valamint az Osztrák-Magyar Monarchia Montenegróval közös határszakaszán csak vámellenőrzés folyt.

A magyarországi határforgalom-ellenőrzését 1906 legelejétől a Magyar Királyi Határrendőrség látta el más hatóságok — például a vámhivatalok) bevonásával. A határrendőrséget létrehozó törvény felsorolta annak feladatait, amelynek jelentős részét a határátkelőhelyeken vagy az államhatár mentén kellett végeznie. ${ }^{32}$ A törvény végrehajtásáról szóló belügyminiszteri rendelet e feladatokat részletezte és azok végrehajtási módját írta elö. ${ }^{33}$

A határforgalom-ellenőrzését részletesen szabályozó, 1905. XII. 29-én kelt belügyminiszteri rendelet és a mellékleteként megjelent útlevélkezelői utasítás az úti okmány ellenőrzés végrehaj-tásának módját és sorrendjét - korabeli megfogalmazás szerint ,az utlevélvizsgálat mikénti telje-sítését” pontosan meghatározta. ${ }^{34} \mathrm{Az}$ útlevelek és a határátlépésre jogosító igazolványok vizsgálatát az 1906. I. 15-én életbe lépő utasítás úgy szabályozta, hogy :

„... - az érvényesség megállapítása után a főfigyelem arra fordítandó, hogy;

„.. . - a személyleírási adatok a felmutató tulajdonosra illenek-e;

„.. . - ha rendben találtattak, az e célra szolgáló bélyegzővel lebélyegezendők és;

". . . - a statisztikai adatgyüjtéshez szükséges adatok feljegyzendők." ${ }^{35}$

Az érvényesség vizsgálatából adódott, hogy ellenőrizni kellett az úti okmány szabályos kiállítását, és az eredetiségét is. A személyek ellenőrzése során alkalmazni kellett a kitiltási és a - gyakran személyleírással kiegészített - körözési nyilvántartásokat is. ${ }^{36} \mathrm{E}$ végrehajtási mód a későbbi évtizedekben csak annyiban változott, hogy a személyleírás ellenőrzésénél az úti okmányban - 1914/1915. fordulójától kezdődően - elhelyezett fényképet is vizsgálni kellett, továbbá a kötelezővé váló láttamozás (vízum, utazási engedély) meglétét és érvényességét is. ${ }^{37}$ Ez lényegében egy évszázad alatt alig változott. Az útlevél kezelői tevékenységet ellátó személyek feladata az I. világháború idején további szempontok és körülmények vizsgálatával egészült ki.

Az útlevelet kezelő hatósági személyek a háború kitörése előtt - a jogosult fényképének hiányában - a határt átlépni szándékozó személyt az úti okmányokban szereplő személyleírás adatai alapján azonosították. Ez azonban részint szubjektív volt, hiszen függött a kiállító személy megítélésén, a leíró kifejezések általános mivoltán és az ellenőrző megállapításán is. ${ }^{38} \mathrm{Az} 1905$ decemberi útlevélkezelői utasítás külön hangsúlyozta a személyazonosítás szükségszerüségét és fontosságát, s „ . . . bebizonyitásának minden módja megengedendő a feltartóztatott utasnál . . ", ${ }^{39}$ ugyanis már ekkor is gyakori volt a más részére kiállított útlevéllel történő utazás. ${ }^{40}$ Ezen elkövetési mód a háború kitöréséig elsősorban a „nőcsempészettel”, vagy a kivándorlás szabályainak megsértésével függött össze. A hamis 
vagy hamisított útlevelet, illetve a más nevére szóló úti okmányt felhasználó felfedésekor jegyzőkönyvet vettek fel a határátkelőhelyen, az okmányt lefoglalták, és azt bünjelként csatolták hozzá. ${ }^{41}$

Amennyiben az útlevél ellenőrző személy a megfelelő úti okmány hiányát, vagy annak szabálytalan kiállítását észlelte, illetve az utazó „más szempontok alapján kifogás” alá esett, akkor a beléptetést meg kellett tagadni. A korábban említett rendőri célok között már ekkor is szerepelt, hogy a körözött személyek felfedésre kerüljenek, annak céljából, hogy a szükséges eljárás lefolytatható legyen velük szemben. ${ }^{42}$

A határt átlépők ellenőrzése során a kémkedéssel gyanúsítható személyeket le kellett tartóztatni, vagy bizonyíték hiányában, átlépésük jelentésével egyidőben intézkedni kellett a megfigyelésükröl. Ebből adódóan a postagalambok behozatalát fokozottan figyelemmel kísérték, és az illetékességi területen részletekbe menő kimutatást vezettek e galambok birtokosairól és az állományukban bekövetkezett változásokról is. Ezeken túlmenően a határt átlépőktől adatot kellett gyüjteni „ . . . az állam biztonságának és nyugalmának megzavarására. . . ” alkalmas eseményekről, és az „államellenes, izgatást tartalmazó nyomtatványok . . .” becsempészését is meg kellett akadályoznia az ellenőrző hatósági személynek. Ugyanígy az útlevélkezelőknek meg kellett akadályozniuk az engedély nélküli kivándorlási ügynökök belépését, a körözött személyek kilépését, illetve a nőcsempészet érintettjeinek átlépését is. ${ }^{43}$ Meg kellett a belépését tagadni az Oroszországból kiutasított nem magyar állampolgároknak és a szerb majom- és medvetáncoltatóknak is. ${ }^{44}$ További feladatok kerültek meghatározásra az államhatár mentén, amelyek az átkelőhelyek területén kívül történő események megakadályozását vagy felderítését célozták, például a határjelek védelme, a csempészet meggátolása. Természetesen az illetékességi területen, mélységben számos feladatot látott el a Magyar Királyi Határrendőrség, amelyek jelentős része a határforgalom-ellenőrzéshez közvetve kapcsolódott.

A diplomaták és a nemzetközi jogon alapuló mentességet élvező személyek átléptetésének - a XX. század első másfél évtizedében is - külön figyelmet kellett szentelnie az úti okmányt ellenőrző közegeknek: „ . . . a külföldi diplomatia tagjait, ha személyiségük ismeretes, utlevelük felmutatására felhívni nem kell; ha pedig erre mégis felhivatnak, útlevelük nem láttamozandó . .." (bélyegezendö). Az úti okmány nélküli határátlépésre, az említett szük körön kívül lehetősége volt még a határátkelöhelyek személyzetének - élelem vásárlás céljából a legközelebbi piacig - és megha-tározott határmenti települések lakóinak is a túloldali szomszédos városba utazáshoz, amennyiben személyazonosságuk ismert volt az útlevél-ellenőrző hatósági személyek előtt. Mindezeken túl, általá-nos szabály volt, hogy a Magyarországon megszakítás nélkül keresztül utazókat útlevél nélkül is be-léptethették, még akkor is, ha úticéljuk valamelyik osztrák település volt. ${ }^{46}$ (Az átutazóktól abban az esetben megkövetelték az útlevelet, ha az átlépő utazásának célja kivándorlás volt.) Ez utóbbiból is látható, hogy a magyarországi útlevél-ellenőrző hatóságok elsősorban Magyarország államhatárát ellenőrizték és nem az OsztrákMagyar Monarchia határait, még akkor sem, ha azok részlegesen lefedték egymást.

A határforgalom-ellenőrzés témakörében 1905. decemberében keletkezett belügyminiszteri rendelet - az okmányellenőrzés végrehajtása mellett - részletesen szabályozta a különböző átkelőhelyfajtákon (közúti, vasúti és vízi) keresztül átlépők ellenőrzésre jelentkezésének módját is.

- A gépjármü, kocsi- és gyalogközlekedéshez igénybe vett utakon a határátlépés céljából érkező utas köteles volt az útlevél-vizsgálattal megbízott hatóság (határátkelőhelyen kijelölt) hivatalos helyiségében átlépésre jelentkezni és ott okmányait átadni. ${ }^{47} \mathrm{~A}$ magyar államhatáron át közlekedő gépjármüvektől 1910 nyarától megkövetelték - az ovális alapú betűjelzéses - felségjelzés és a forgalmi engedély (korabeli kifejezéssel gépjármü nemzetközi úti igazolvány) meglétét is. Amelyik gépkocsi nem rendelkezett ezzel, vagy olyan országból érkezett, ahol ilyet nem állítottak ki, azt a határvámhivatal és a határrendörség helyi szervezete elláthatta ideiglenes engedéllyel, esetlegesen a szükséges kötelmek elóírásával. ${ }^{48}$ Erre szükség volt például a szerbiai, a montenegrói, a romániai vagy a törökországi bejegyzésü gépkocsik esetében is.

- A vasúti határátkelőhelyek esetében, általánosságban, a vonat utasainak - a szerelvény határállomásra történő befutását követően - a vámvizsgálat céljából, poggyászaikkal el kellett hagyniuk a kocsikat, amelyet a rendőrhatóság járöre felügyelt és ellenőrzött. ${ }^{49} \mathrm{Az}$ útlevél-ellenőrzést a határrendörség, az állomás épületén belül, az e célra kijelölt külön helyiségben hajtotta végre. Azonban a szolgálattételre kirendelt csendőrség vagy rendőrség az útlevélvizsgálat alatt az útlevélvizsgáló teremben a rend fenntartására és arra ügyelt, hogy az útlevél előmutatása nélkül a teremből senki se távozhasson. ${ }^{50}$ A szerelvény elhagyásának kötelezettsége alól kizárólag azok mentesültek, akik szalonvagy hálókocsiban utaztak és ismert előkelőségek, vagy súlyosan beteg egyének voltak. Az ő úti okmányaikat a vasúti jegyvizsgáló vitte az útlevélkezelő határrendőrhöz, aki ezt követően meggyőződhetett arról, hogy az említett személyeken kívül nem utazik-e más a vonaton. ${ }^{51}$ Azon, külön 
meghatározott vonatokon, amelyeknél a vámvizsgálathoz az utasoknak nem kellett a jármüről leszállni, ott az útlevél vizsgálata a vonaton történt, ilyenek elsősorban a keletre tartó gyorsvonatok voltak. Akik Magyarországból érkezve, csak a határállomásig utaztak, azaz belföldi viszonylatban közlekedtek, azokat a fent leírt ellenőrzés alá nem vonták, az állomást minden további nélkül el-hagyhatták.

- A vízi határforgalom ellenőrzése általánosan csak a dunai kikötőkben folyt, Fiumében kizárólag a kivándorlókat illetve gyaníthatóan kivándorlókat vizsgálták. A legfontosabb magyar folyami határátkelőhely Orsova volt, ahol a Duna ezt követően végérvényesen elhagyta a magyar partokat. A Magyarországról kilépő utasok esetében, az Orsovából Romániába induló hajók utasainak ellenőrzését a beszállást követően, de még az indulás előtt, a hajón hajtották végre. A Zimony és Orsova között közlekedő személyszállító hajók — amelyek kikötöttek szerb parton is — utasainak úti okmányát az e célra kirendelt határrendőrök vizsgálták, menet közben. Azon hajók esetében, amelyek az előbbi viszonylathoz képest még romániai kikötőkbe is tovább mentek, ott csak az Orsovában felszálló utasok okmányait ellenőrizték beszállás közben. ${ }^{52}$ A Magyarországra, a Duna alsó folyásáról érkező hajók utasainak esetében az útlevél-ellenőrzést Orsován ejtették meg. Minden utasnak el kellett hagynia a hajó fedélzetét és a kikötőépület útlevélvizsgálatra kijelölt teremében estek ellenőrzés alá. A személyek és okmányaik vizsgálatát követően a határrendőröknek a hajó helyiségeit át kellett kutatnia, hogy nem maradt-e a fedélzeten vagy nem rejtőzködött-e el utas. ${ }^{53}$ Természetesen nemcsak a nagyobb hajókon, hanem minden, így akár a kézi meghajtású úszó jármüvön közlekedő személyt is ellenőrizni kellett.

- A légi forgalom részére nem volt kijelölt határátkelőhely és az ellenőrzés is eltért a szárazfölditől. A polgári légi járművel érkezőket csak leszállásukkor kellett megfigyelni, de igazoltatásuk nem volt kötelező, azonban körültekintőnek kellett lenni az esetleges kémkedés miatt. ${ }^{54} \mathrm{~A}$ katonai légi jármüvek személyzetének határátlépéséről már 1899-ben született Magyarországon rendelet, de ezt csak a német katonák részére tették lehetővé, a meghatározott feltételek mellett. ${ }^{55} \mathrm{~A}$ légi határforgalom rendkívül csekély volt, számos okból kifolyólag, így a hatótávolság, az anyagi lehetőségek és közlekedési szokások miatt is.

A Magyar Királyságból az Osztrák Császárságba utazók számára — a kivándorlás céljából távozók kivételével - nem volt szükséges úti okmány. Az Osztrák Császárság és a Magyar Királyság közös határvonalát a Magyar Királyságból átlépők esetében ez azt jelentette, hogy a határforgalmat ellenőrző személyek csak a kivándorlásgyanús személyeket ellenőrizték. Ugyanezt az eljárást alkalmazták Magyarország és Horvátország határán is. A korabeli fogalomrendszer szerint kivándorlónak azt tekintették, aki 1 évnél hosszabb idejü munkavállalás céljából kívánt külföldön tartózkodni. ${ }^{56}$

Változások a határforgalom ellenőrzésében 1912-1913-ban, a Balkán-háborúk idején jöttek létre. Az első jelentős csaták - a november közepén kezdődött, Drinápoly (Edirne) környéki ütközetsorozatok, illetve az észak-macedóniai szerb támadás - kibontakozását követően, 1912. XII. 1-jével a magyar miniszterelnök ismét elrendelte a Szerbia viszonylatában határt átlépni szándékozókkal szemben a — két évvel korábban megszüntetett — útlevél-kötelezettséget. ${ }^{57}$ Ennek oka a rendelet szerint rendészeti volt, amely magában foglalta a hadban álló balkáni országba illetve országból utazók fokozottabb ellenőrzését, különös tekintettel a kémgyanús személyek kiszürésére és az átlépő személyeknél lévő, hadászati szempontból értékes tárgyak felfedésére. A magyar-szerb határszakaszon az útlevélkötelezettséget a háborúk 1913 közepén, békével történt lezárást követően sem szüntették meg.

\section{Az osztrák-magyar hadüzenetig vezető út és a feszültség kihatása a magyar határforgalom- ellenőrzésre}

Már 1914 januárjának legvégén életbe lépett azon kölcsönösségi szabály, miszerint a magyar határrendőrségi hatóságok fokozottan ellenőrizték az osztrák, illetve a bosznia-hercegovinai 17 és 35 év közötti férfiakat - akik Magyarország, és így az Osztrák-Magyar Monarchia területét szándékoztak elhagyni —, azon szempont szerint is, hogy hadkötelezettségüknek az elöírások szerint eleget tetteke. ${ }^{58}$ Ugyanez, viszonosság alapján vonatkozott az Osztrák Császárság vagy Bosznia-Hercegovina külső határát átlépő magyar férfiakra is az ottani hatósági vizsgálatok által. ${ }^{59}$

1914. VI. 28-án délelőtt — Bosznia-Hercegovina székhelyén — Szarajevó városában szerb merénylő Ferenc Ferdinánd trónörököst és feleségét lelőtte. Alapos és kiterjedt nyomozás indult a merénylet körülményeinek megismerésére. Az Osztrák-Magyar Monarchia és Szerbia közötti légkört e gyilkosság nem élezte ki azonnal, de hamarosan a nyomozás mind több szála Szerbiába vezetett. A merényletet követő első két hét nem hozott semmilyen számottevő lépést Európában és még az Osztrák-Magyar Monarchia értéktőzsdéire sem gyakorolt hatást. ${ }^{60}$ Raymond POINCARÉ francia elnök, a 
miniszterelnök társaságában, 1914. VII. 16-án még diplomáciai úton megoldhatónak találta az esetet annyira, hogy a négy hónapja tervezett oroszországi és skandináviai látogató körútjára induljon. ${ }^{61}$

Azonban július második felétől az Osztrák-Magyar Monarchiában megkezdődött a politikai, majd a katonai készülődés egy újabb, balkáni háborúra, amelyet immár a dualista államalakulat kezdeményezett volna. Bár a dunai monarchia mindkét társországának kormánya igyekezett volna helyi háborúként lefolytatni az összecsapást, Németország reménykedett, hogy ez - a szövetségi rendszerek révén - egész Európára hatást gyakorol, és elsősorban Oroszországot kényszeríti hadba vonulásra. ${ }^{62} \mathrm{~A}$ nagyhatalmak szövetségeseiket hamarosan támogatásukról biztosították egy fegyveres összecsapás esetére, megerősítve korábbi szövetségesi szerződéseiket. Így a Német Császárság is feltétel nélküli támogatását ajánlott az Osztrák-Magyar Monarchia részére a leendő új háborúban.

A Szerbiával szembeni, esetleges fegyveres összetűzés miatt már 1914. VII. 20-án a magyar miniszterelnök rendelkezett a déli államhatár és jelentős mélységben a határvidék légterének korlátozásáról. A rendelettel tilalmi zónákká nyilvánították a magyar és a külföldi légi jármüvek előtt Magyarország déli vármegyéi légterének nagy részét, amely határközeli hajózó utakat, kulcsfontos-ságú vasútvonalakat és -csomópontokat is magába foglalt ${ }^{63}$ (II.sz. melléklet) E légtérben csak külön engedéllyel lehetet közlekedni, amely korlátozás azonban nem vonatkozott a fegyveres erök használa-tában álló vagy érdekében müködő légi járómüvekre". ${ }^{64}$ Ezzel értelemszerüen megszüntették a déli határszakasz jelentôs részén az áthaladó - mellesleg jelentéktelen - légi határforgalmat is.

Báró Wladimir GIESL von Gieslingen altábornagy az Osztrák-Magyar Monarchia nándorfehérvári követe, 1914. VII. 23-án továbbította az Osztrák-Magyar Monarchia jegyzékét a szerb kormányhoz, amely a merénylet eseményeit és a merénylőnek a szerb hivatalos körökhöz füződő kapcsolatát követelte tisztázni, a szerb belügyekbe való beleszólás. ${ }^{65}$ Minderre a szerbek számára a jegyzék két napot biztosított. E lépéssel kezdődött el az a folyamat, amely a két ország fegyveres konfliktusába torkollott.

A magyar határ túloldalán elterülő Nándorfehérvárból 1914. VII. 25-én Szerbia mélységébe kezdték költöztetni a szerb kormányhivatalokat, a Szerb Nemzeti Bank és az állami vasúttársaság pénzvagyonát, és már délután három órakor elrendelték a szerb általános mozgósítást is. ${ }^{66}$ Ugyanezen a napon, pár perccel délután hat óra előtt az Osztrák-Magyar Monarchia nándorfehérvári követségén Nikola P. PAŠIĆ szerb miniszterelnök átadta — az egy kivételével elfogadott feltételekről szóló —válaszjegyzéket. Azonban a követelések nem teljeskörü teljesítése miatt az Osztrák-Magyar Monarchia követe rögvest közölte, hogy így megszünt a diplomáciai kapcsolat a két ország között. ${ }^{67}$ Az OsztrákMagyar Monarchia nagykövetségének a személyzete délután hat óra után elhagyta a szerb fővárost, vasúton Zimonyba utazott. ${ }^{68}$ Aznap este a román Bessaraba személyszállító gőzös ingajáratban hazaszállította Nándorfehérvárból az ott dolgozó osztrák és magyar állampolgárokat, Zimonyból a szerb alattvalókat Szerbiába vitte. ${ }^{69}$ I. Ferenc József a szerb válasz hatására nem sokkal este fél tíz előtt elrendelte a részleges mozgósítást. Másnapra a magyar-szerb határforgalom a legszükségesebbre korlátozódott olyannyira, hogy az ausztriai üdüléséből hazatérőben lévő Radomir PUTNIK vajda, szerb vezérkari főnök - akit 1914. VII. 25-én késő este a budapesti Kelenföldi pályaudvaron, a katonai és politikai vezetés tudtával előállítottak, majd rövidesen, I. Ferenc József király és császár közbenjárá-sára elengedtek - 1914. VII. 26-án már Románián keresztül térhetett haza a rendelkezésére bocsátott különvonattal. ${ }^{70}$ Az előző napi eseményekre már 1914. VII. 26-án érzékenyen reagált az Osztrák-Magyar Monarchia pénzpiaca, a betétesek tömegével igyekeztek készpénzre váltani banki megtakarí-tásaikat és sokan a bankjegyeiket is nemesfém érmékre kívánták becserélni. A kialakult helyzeten az OsztrákMagyar Bank több intézkedéssel igyekezett úrrá lenni, miközben tartalékai jelentősen csök-kentek. A részvénypiac összeomlásának megelőzése céljából a magyar tőzsde működését már 1914. VII. 27-én felfüggesztették. ${ }^{71}$

1914. VII. 26-án, azonnal életbe lépett az a belügyminiszteri rendelet, amely - elörevetítve a másnapi osztrák-magyar hadüzenetet - Magyarország Szerbiával közös határszakaszának határátkelőhelyeit csak azzal a feltétellel engedte nyitva tartani, illetve igénybe venni, ha azt az alispán (kormánybiztos) a katonai területi parancsnoksággal egyetértőleg erre a célra megállapítja, és csak abban az esetben, ha a határt átlépni kívánó magát és utazásának célját kellően igazolja. ${ }^{72}$ Egyúttal ezen rendelkezés magyar állampolgárságú megszegöit elzárással és pénzbüntetéssel, a külföldieket kiutasítással és kitoloncolással szankcionálta. Ugyanazon a napon a kivándorlás elé korlátot emelt a magyar miniszterelnök azáltal, hogy a véderőtörvényben megjelölt férfiak kivándorlását egy évre megtiltotta, ${ }^{73}$ valamint a fegyveres erő kötelékébe tartozó és tényleges szolgálatban nem álló személyek részére az útlevelek beszüntette. A kivételeket a belügyminiszter illetve a horvát-szlavón bán a honvédelmi miniszterrel egyetértöleg határozhatta meg. ${ }^{74}$ Ugyanekkor a miniszterelnök a belügyminiszter, illetve a 
bán hatáskörébe utalta az útlevélkiállítás jogát Magyarország erdélyi és déli vármegyéinek, továbbá Fiumének illetve Horvát-Szlavónország területén, ${ }^{75}$ amelyet majd 1914. VIII. 1-jén kiterjesztett az ország egész területére. ${ }^{76}$ E napon, 1914. VII. 26-án a magyar miniszterelnök rendeleti úton bevezette a montenegrói állampolgárokkal szemben az útlevél-kötelezettséget, az 1914. VIII. 5-ei hadüzenettel pedig megszünt a montenegróiak beutazása. ${ }^{77}$ Szintén e naptól a postai és távirati forgalmat is korlátozták, és lehetővé tették azok tartalmának hatósági vizsgálatát, a küldemények visszatartását. Magántáviratokat a magyar, illetve horvát mellett kizárólag német, francia, angol vagy olasz nyelven lehetett feladni, más nyelven táviratot felvenni vagy kézbesíteni tilos volt. ${ }^{78}$

1914. VII. 26-án a brit, 1914. VII. 27-én az orosz kormány tett kísérletet a vitás felek közötti közvetítésre, azonban mindkettő próbálkozás elutasításra talált, előbbi a Német Császárság, utóbbi az Osztrák-Magyar Monarchia részröl. ${ }^{79}$

1914. VII. 28-án Leopold von BERCHTOLD gróf, az Osztrák-Magyar Monarchia külügyminisztere a szerb külügyminisztériumnak nem sokkal dél előtt, francia nyelvü táviratban a következö jegyzéket küldte meg: „Miután a szerb királyi kormány nem adott kielégítő választ arra a jegyzékre, melyet Ausztria-Magyarország belgrádi követe 1914. VII. 23.-án átadott, a császári és királyi közös kormány kénytelen maga gondoskodni jogainak és érdekeinek védelméröl és evégből a fegyverek erejéhez folyamodni. Ausztria-Magyarország ennélfogva a jelen pillanattól fogva Szerbiával hadiállapotban lévönek tekinti magát." ${ }^{, 80}$ Raymond POINCARÉ és miniszterelnöke, bár már 1914. VII. 24-e hajnalban értesült az osztrák-magyar ultimátumról, majd később a fejleményekről is, azonban körútját csak a 1914. VII. 28-ai hadüzenetet követően szakította meg, és tért vissza Franciaországba. ${ }^{81}$

\section{A hadban álló Magyarország határforgalom ellenőrzése, 1914-1918}

A hadüzenettel egyidőben lezárult az Osztrák-Magyar Monarchiának a Szerb Királysággal közös határszakasza a polgári határforgalom előtt, s még aznap délután megkezdődtek az első helyi, kisebb összecsapások a hadviselő felek járörei között. ${ }^{82}$ A két ellenfél hadseregeinek egységei először 1914. VII. 29-én 02:20-kor csaptak össze, az Osztrák-Magyar Monarchia haditengerészete dunai flottillájának Temes monitora lőni kezdte a szerb főváros Kalemagdánnál lévő ütegeit. Fél órával később a szerbek megkezdték a zimonyi - Magyarországot Szerbiával összekötő egyetlen - vasúti híd felrobbantását, amely ekkor még csak fél sikerrel valósult meg. ${ }^{83}$ Az általános mozgósítást $I$. Ferenc József 1914. VII. 31-én rendelte el.

Ezen évek diplomáciai nyelvezete szerint, amennyiben egy követnek, nagykövetnek a fogadó állam külügyminisztériuma kérés nélkül kiadta az útlevelét, akkor az egyenértékủ volt a kiutasítással, a diplomáciai kapcsolatok megszüntetésével. Erröl, többek között az Osztrák-Magyar Monarchia külügyminisztere által a Belga Királyság külügyminiszterének 1914. VIII. 22-én táviratban megkül-dött jegyzéke, azaz a hadüzenet ad képet: „Ausztria-Magyarország kénytelen a diplomáciai össze-köttetést Belgiummal megszakítani és vele ettől a pillanattól kezdve hadiállapotban levőnek tekinti magát. ... Errembault DE DUDZEELE grófnak Belgium bécsi követének, kézbesítette útleveleit” ${ }^{84}$ Az 1914 július végi, augusztusi hadüzeneteket követően, az Osztrák-Magyar Monarchia külügyminisztériuma az immár ellenséges hadviselő országok diplomáciai és konzuli képviseleteinek személyzetét távozásra késztette. A diplomáciai testületek tagjainak távozását a beálló hadi állapottól függetlenül biztosították.

A háború kitörésének első heteiben a lényegi változást az jelentette, hogy a hadkötelesek és katonák kiszürése, illetve a kémek elfogása kiemelt szerephez jutott. Az 1914-ben újabb magyarországi korlátozó szabályok már nem születtek, így az Osztrák-Magyar Monarchia mindkét társországa részéről újabb útlevél- vagy vízumkényszer sem került bevezetésre. Külföldön ellenben megkezdődött a beutazások előzetes, külképviseleti ellenőrzésének fokozatos bevezetése. Elsőként, 1914. XII. 15-től az Amerikai Egyesült Államok útlevélhatóságai angol nyelvủ záradékkal az okmány tulajdonosának arcképét is rögzítették az útlevélen. ${ }^{85}$ A hadviselő felek közül Németország 1915. I. 1-jétől elsőként vezetett be az Amerikai Egyesült Államokéval azonos rendelkezést német nyelvü záradékkal. ${ }^{86}$

Az Osztrák-Magyar Monarchia két társországa számos árucikk tekintetében még a háború kitörése előtti napon, 1914. VII. 27-én bevezette a „külső” határain ki- és átviteli tilalmat. ${ }^{87}$ Kezdeti napokban a tiltás szinte kizárólag a hadianyagra, vagy a katonai felhasználásra alkalmas árukra terjedt ki, azonban már 1914. VIII. 1-jén kiegészült számos ipari termékkel és alapanyaggal, valamint élelmiszerrel és azok alapanyagával is. ${ }^{88}$ A kiviteli tilalom alá eső áruk és nyersanyagok listáját hamarosan újabb és újabb rendeletek bővítették ki. Azonban a határszéli forgalomban közlekedők szükségletei fedezésére szolgáló áruk és élelmiszerek még több mint két évig nem estek e szabályzók által szigorúbb korlátozás alá. A gépjármüvel, kerékpárral vagy állati vontatású eszközökkel történő forgalom a 
vámhatáron keresztül már a háború kitöréséről is csak rendőrhatósági engedéllyel, az eszköz visszahozásának kötelezettsége mellett, a meghatározott határvámhivatalon keresztül volt engedélyezve. Kivételt csak a postaszolgálatnak, a határon át közlekedő postajárat jármüvei képeztek. Jármüvek tekintetében külön engedélyeket az alispánok és polgármesterek az illetékes katonai kerület-parancsnokság hozzájárulásával adhattak. A meglévő engedélyek ellenőrzése természetesen a határátkelőhelyeken szolgálatot teljesítő hatósági személyek feladata volt. Lehetősége volt a határhoz közeli területi helyhatóság vezetőjének, hogy a pénzügyigazgatóság hozzájárulásával, a kettősbirtokosok részére engedélyt adjon földjei megmủveléséhez, nemcsak a tilalom alá eső - de kivitelét indokoltnak tartott - eszközök és állatok kivitelére, de arra is, hogy a határt „saját igás-, teherhordó- vagy legelőmarháikkal mellékutakon átléphessék". ${ }^{89}$ A kishatárforgalomra vonatkozó kedvezmények Románia hadba lépése nyomán kerültek felszámolásra. ${ }^{90}$

Mialatt 1914 öszén, a Romániával közös határszakaszon békés körülmények között folyt a korábbi mértékhez képest lecsökkent határforgalom, addig már 1914. IX. 18-án az Uzsoki- és Duklai-hágó térségében betörtek Magyarországra is az orosz cári csapatok. Hamarosan már megszállva tartották az északkeleti magyar megyék több járását is. Kiszorításukat követően az oroszok 1914. XI. 15-én, majd 1915 január végén törtek be ismét Magyarország területére, ahonnét majd csak 1915 április első felében indított támadás hatására tudták kiszorítani őket Galíciába, majd a későbbi hónapok során mind keletebbre. Ezalatt a déli fronton lényegében állóháború alakult ki, ahol az Osztrák-Magyar Monarchia haderejének csapatai csak ideiglenes hídfóállásokat tudtak kialakítani.

A magyar miniszterelnök 1915. I. 20-tól rendelte el a Magyarország „külső” határait átlépők részére, hogy - állampolgárságtól függetlenül - azt csak az esetben tehették meg, ha az útlevelükbe hivatalosan csatolták és záradékolták a jogosultak fényképét. ${ }^{11}$ Az Osztrák Császárságban ugyanekkor azonos rendelet lépett életbe. Ez új fejezetet nyitott a határforgalom-ellenőrzés történetében, hiszen az úti okmányokat az addigi - általános, személytől függően értelmezhető megfogalmazással körülírt személyleírások mellett, az adott személy beazonosítását ténylegesen lehetővé tevő tulajdonsággal bövítették. Ezen rendelet előírta még, hogy - az osztrák, a magyar és a liechtensteini állampolgárokat és boszniai illetőségüeket kivéve - a külföldiek beutazásához az Osztrák-Magyar Monarchia külképviselei előzetes láttamozása, azaz vízuma is szükséges. ${ }^{92}$ A rendeletben foglaltakat nem teljesítő személyek beléptetését meg kellett tagadni, függetlenül úti céljától vagy utazásának megkezdésétől. ${ }^{93} \mathrm{~A}$ rendelet azonban a határszéli forgalomban - napjaink terminológiája szerinti kishatárforgalomban — közlekedőkre vonatkozó kétoldalú megállapodásokat nem változtatta meg. Továbbra is a korábbi rendelkezések alapján kiállított - nyolc napig és egyszeri utazásra érvényes - határszéli úti igazolványok voltak elfogadhatóak. Ezen úti okmányok így fénykép és láttamozás nélkül is érvényesek voltak, bár Háromszék vármegyétől nyugatra eső átkelőhelyek — mivel hadműveletei területre estek — ${ }^{94}$ eleve fényképes okmánnyal voltak igénybe vehetők. ${ }^{95}$ A háború előtti és alatti gyakorlat közötti eltérést érzékelteti, hogy a belügyminiszter 1915 nyarán kiadott, kapcsolódó rendeletében külön utasította a belföldi hatóságokat, hogy figyelmeztessék a román határszakaszon átlépni szándékozó személyeket, hogy a határszéli rendőrhatóságnál útlevelüket felszólítás nélkül mutassák be. ${ }^{96}$ A miniszterelnök az útlevélellenőrző hatóságok tagjai részére kihangsúlyozta, hogy amennyiben az utazó személy határátlépését megengedhetőnek tartják, akkor útlevelét láttamozni, azaz átléptető-bélyegző lenyomatával ellátni voltak kötelesek, bár ez a korábbi években sem volt másképpen. ${ }^{97}$

Az Osztrák-Magyar Monarchia társországainak határforgalom-ellenőrző hatóságai a háború ellenére - bár a korábbi mértéket el nem érve, de - továbbra is számottevő átutazó személyforgalmat ellenőriztek. A határforgalomban a dualista államalakulattal szövetséges vagy az Osztrák-Magyar Monarchia által megszállt területek, illetve a semleges államok polgárai vettek részt. Azonban semleges országok utazói egy részének végcélja, egy közbeiktatott semleges államon keresztül akár ellenséges hadviselő állam is lehetett. ${ }^{98} \mathrm{Az}$ ő ellenőrzésük - ha végleges úti céljuk ismerté vált az útlevélkezelők elött - szintén nagy jelentőséggel bírt, többek között kémelhárítás szempontjából is.

Egyre több név szerepelt a kitiltottak magyarországi listáján is, amelyen akár német, sőt még osztrák állampolgárok is szerepeltek. A háború kezdetétől fogva nött a kitiltott külföldiek száma, ezzel e nyilvántartás átnézése is valamelyest hosszabb időt vett igénybe az ellenőrzés során. ${ }^{99}$ A hadmüveleti területeken, illetve a határon történő ellenőrzések alkalmával, már a kezdeti hónapokban számos esetben fedtek fel a határőrizeti szervezetek kémeket továbbá kémkedéssel gyanúsítható, vagy legalább is megfigyelendő személyeket. Az elfogások nagyobb arányban a hadmúveleti területek közelében fordultak elő, mivel ott ezen üldözendő cselekmény végrehajtása közben, vagy azt követően könnyebb volt az elkövetöre bizonyítani a vádat. A lengyel származású - és így Galíciában nyelvi ne- 
hézség nélkül müködő - orosz kémek mellett például Ung vármegyében és vidékén brit, sőt hazája semlegessége ellenére spanyol és argentin kémeket is bíróság elé állítottak. ${ }^{\mathbf{1 0 0}}$

A háború elöre haladtával, a határ- és a határforgalom-ellenőrzés hatósági szerkezetének valamelyest átalakítása vált szükségessé. Azoknál az átkelőhelyeknél, ahol a csendőrség látta el az útlevélkezelés feladatát is, egy korábbi, háború esetére kidolgozott határvédelmi terv szerint szervezték át. A Magyar Királyi Határrendőrség által végrehajtott, egyre összetettebb ellenőrzési feladatok miatt több alkalommal is létszámkiegészítésre szorult. A határrendőr kapitányságokhoz a honvédség alakulataitól jelentős számú katonát - köztük tiszteket és altiszteket is - vezényeltek szolgálattételre, akiket arra az időre, 1916 nyarától a kapitányság székhelye szerint területileg illetékes honvéd kerület-parancsnokság alárendeltségébe helyeztek. ${ }^{101}$ A Magyar Királyi Határrendőrség saját állományának bövítése céljára 1917. október közepén 150, majd 1918. augusztusának végén újabb 150 határrendőri beosztás betöltésére hirdettek meg pályázatot. ${ }^{102} \mathrm{~A}$ fiumei határrendőr kapitányság feladatai és állománya 1917. V. 1-jétől a Fiumei Magyar Királyi Állami Rendőrségbe tagozódott, így ekkortól a határforgalom ellenőrzését is ennek hatósági személyei látták el. ${ }^{103}$

A magyar-román viszonylatban mind kisebb határforgalom miatt, idővel számos - korábban is kisforgalmú, elsősorban helyi jelentőségü - határátkelőhely megszüntetésére került sor. ${ }^{104}$ A román kormány 1915. szeptemberi intézkedése folytán - bár elvileg továbbra is a központi hatalmak szövetségese, de egyúttal e háborúban semleges volt - a román-magyar határszakasz hadászatilag fontos útvonalai mentén, így a határon átvezető vasútvonalak kezdeti szakaszainál is, lövészárkokat, farkasvermeket és szögesdrót-akadályokat létesítettek. ${ }^{105}$ Ennek ellenére a magyar, illetve az osztrák-magyar katonai vezetés nem telepített katonai erőt az államhatárhoz közel. Itt továbbra is a csendőrség és a pénzügyőrség határmenti alegységei (őrsök, szakaszok) biztosították a fegyveres jelenlétet, akik feladata - létszámukból adódóan is - a csempészet és a jogellenes határátlépés megakadályozása illetve a határforgalom felügyelete volt. ${ }^{106}$ A magyar-román viszonylat vasúti határátkelőhelyein szolgálatot teljesítők részére jelentős feladatként hárult az Osztrák-Magyar Monarchia államaiban élő, de hazatérni szándékozó ellenséges országok állampolgárainak kiléptetése, valamint a kölcsönösség elvén az ellenség államaiból csoportosan hazautazó magyarok és osztrákok beléptetése. A haza-bocsátások időröl-idöre az osztrák és a magyar belügyminiszterek engedélyezésével és szervezésével zajlottak. Az első alkalmakkal, 1915. májusában és júniusában, több csoportban a vagyontalan szerb állampolgárokat léptették ki a vöröstoronyi határátkelőhelyen. Ezek során az ellenőrzés alatt tartott különvonaton Szerbiába hazatérni kívánókat és névjegyzéküket a határrendőr kirendeltség vezetője és beosztottjai átvették, ellenőrizték, majd kiléptették. ${ }^{107}$ Ezzel közel azonos időben, ugyanitt léptették be a Szerbiából hazautazó magyarok és osztrákok csoportjait is. A vagyonnal rendelkezők saját költségen, szintén csoportosan, de felügyelet nélkül, érvényes útlevél birtokában, külön kijelölt átkelöhelyeken keresztül térhettek haza Szerbiába. A következő jelentős, szervezett csoport az elbocsátható oroszok voltak 1915. augusztusában. ${ }^{108} \mathrm{Az}$ ő utaztatásuk a szerbekével azonos módon történt, s Budapestet érintve a gyimesbükki vagy predeáli átkelőn keresztül, s a semleges Románián át utazhattak haza, illetve a magyar és osztrák állampolgárok Oroszországból az ellenkező irányból érkeztek vissza. (III. sz. melléklet)

Fiume tengeri határátkelőhelyen történő határforgalom-ellenőrzés szabályait a magyar belügyminiszter 1915. VIII. 18-án a következő képen írta elő: ,,a fiumei szabad kikötőbe külföldről érkező és onnét külföldre induló hajók utasai az útlevél-vizsgálatnak a kikötőbe befutó, avagy ott kikötött hajókon a hajó állama szerint illetékes konzuli hatóság előleges értesítése mellett fognak alávetni". ${ }^{109} \mathrm{Az}$ Adria parti magyar kikötővárosban az európai államok közül, 1914. elején Görög-, Német- és Törökország tartott fenn konzuli képviseletet és megbízással még más államok is. ${ }^{110}$ A hadi helyzet okán, 1915 második felében már csak Romániából, Spanyol- és Görögországból, Hollandiából, a skandináv országokból, Közép- és Dél-Amerika államaiból érkezhetett hajó az Osztrák-Magyar Monarchia tengeri kikötőibe. Azonban ekkorra már az olasz hadihajók is megkezdték tevékenységüket az Adrián. Ebből kifolyólag augusztus végétől török, és október közepétől bolgár hajók - ezen országoknak Olaszországgal történt hadi állapotba kerülésével — nem érkeztek magyar vagy osztrák kikötőkbe.

A határforgalom ellenőrzése során, a háború kitörésével kiemelt lett a hadviselő felek érdekeit sértö tárgyak, eszközök kiszürése, a kémek és a kémkedéssel gyanúsítható személyek elfogása. Ennek részletes és átfogó szabályozásáról 1915. augusztusában adott ki a magyar miniszterelnök rendeletet. ${ }^{111}$ A határon átlépni szándékozó személyek ekkortól leveleiket, irataikat és nyomtatványokat a határforgalom-ellenőrző rendőrhatóságnak bemutatni voltak kötelesek. Az így átadott papírokat - állambiztonsági vagy hadászati szempontból, illetve egyéb szabályokból eredő szempontok szerint - ellenőrizték, illetve vizsgálták, hogy kivitelük vagy behozataluk nem aggályos-e. A vámvizsgálat során ta- 
lált iratokat a határrendőröknek adták át a fenti vizsgálat céljából. ${ }^{112}$ Természetesen ezek el-lenőrzése jelentős munkát rótt a határforgalom-ellenőrző hatósági személyekre és igencsak megnövelte a határátlépés időtartamát is. A postaforgalomban már a háború igen korai időszakában ellenőrizték, azaz cenzúrázták a külföldre vagy a külföldröl küldött levelezőlapok, levelek és táviratok tartal-mát, hogy katonailag fontos adatok ne kerüljenek nyilvánosságra. ${ }^{113}$ A térképek terjesztését 1915. nyarán korlátozták, s ekkortól az úti könyvek és a kisebb léptékü térképek is csak külön miniszteri engedélyekkel voltak külföldre küldhetőek. ${ }^{114}$ A magyar kereskedelemügyi miniszter rendelete hadászati szempontok miatt 1915. novemberétől megtiltotta az Osztrák-Magyar Monarchiában levő városokat, városrészeket, helységeket, tájakat, katonailag fontos tárgyakat, közlekedési és nemzetgazdasági telepeket, különösen kiváló építményeket és emlékmủvet ábrázoló képeslapok külföldre irányuló posta-forgalmát. E tilalom nem érintette az Osztrák Császársággal és Bosznia-Hervegovinával közös forgalmat. ${ }^{115} 1915$ decemberében e korlátozást kiterjesztették az Osztrák-Magyar Monarchiával szövetséges államok és az általuk megszállott területek település- és látképeit ábrázoló nyomtatványaira is, valamint tiltották ezen postaküldemények elöállításához szükséges nyomófelületek szállítását is. ${ }^{116}$ A németországi postaforgalom korlátozása és ellenőrzése 1916 folyamán többször is változott, a „látképes levelezőlapok” Németországba történő továbbítását a magyar kereskedelmi miniszter 1917 december közepétől engedélyezte, de a nyomtatáshoz szükséges negatívak (klisék) továbbra is szállítási tilalom alatt álltak. ${ }^{117}$ Természetesen a határforgalmat ellenőrző közegeknek ezen tárgyak határon át történő szállítását fel kellett fedniük, hiszen postaküldeményeket magánszemély nem vihetett külföldre. ${ }^{118}$

A külföldre utazás körülményeinek további szigorítása 1918. augusztusában lépett életbe, amikor a Svájcba utazóknak mindenféle írott anyagot, fényképet vagy filmet tilos volt magukkal vinniük, ezek csak postai úton voltak továbbíthatóak, ha más korlátozás alá nem estek.

A magyar állampolgárok, és a Magyarországon huzamosan élö külföldiek esetében, 1915. XI. 13tól bevezetésre került, hogy amennyiben a semleges Romániából vagy Svájcból kívántak az OsztrákMagyar Monarchia területére visszautazni, és útlevelük nem tartalmazott visszautazást engedélyezö záradékot, akkor azért még a visszatérésük előtt, az Osztrák-Magyar Monarchia illetékes konzuli hatóságnál kellett folyamodniuk. ${ }^{119}$ A Németországból érkezőkre ezen elöírást nem terjesztették ki. Ettől kezdve az említett záradék meglétének ellenőrzése is az útlevélkezelés részévé vált.

Az elhúzódó háború további megszorításokat hozott létre a különböző termények, termékek, nyersanyagok és élőlények kivitele tekintetében. Így az 1916 március végén kiadott új rendelkezés jelentősen szükítette a határon átkelő személyek birtokában tartható nem engedélyköteles tárgyak körét. Mivel ezek közül számos a köznapi úti poggyászok vagy viselt ruházat tartalma is lehetett, így azok vizsgálatának a tilalom alá eső cikkekre is ki kellett terjednie. Ennek értelmében a vámhatáron tilos volt kivinni, vagy átszállítani - számos meghatározott áru mellett - selyemárut (ideértve valamennyi ruházati terméket is), üres papírt, „zsebtüzszerszámot” és tartozékait, aranyból vagy ezüstből készült tárgyakat és hulladékait, ércpénzt bármely fémböl, látcsövet, fényképezőgépet és fényképészeti kellékeket, gyógy- és kötszert. A fémpénzek közül ekkortól, az utasforgalomban az ezüstből készültek kivitelét legfeljebb 20 korona összértékig engedélyezték külön engedély nélkül, a nem nemesfém váltópénzek értékhatára 10 korona volt. A tilalom alól kivételeket egyedi esetekre vonatkozóan hagytak jóvá, a kisebb határszéli forgalom vonatkozásában pedig elegendỏ volt a kiviteli engedély is. Természetesen a hadiszállításokat továbbra sem korlátozták. ${ }^{\mathbf{1 2 0}}$

Osztrák-Magyar Monarchia és a Német Császárság haderői - bolgár támogatás mellett - az 1915. októberében kezdődő hadmüvelettel december végére megszállták Szerbiát, ahol bevezették a katonai közigazgatást. A Császári Királyi Szerbiai Katonai Főkormányzóság (k. u. k. Militär-General-Gouvernements in Serbien) hamarosan megkezdte a megszállt területeken élők úti okmányainak kiállítását ${ }^{\mathbf{1 2 1}}$ és utazásának engedélyezését, valamint ellenőrzését is. A főkormányzóság intézkedett arról is, hogy a magyar kormánnyal egyetértésben határátkelőhelyek nyíljanak a magyar-szerb határon, 1915 végétől Zimony-Nándorfehérvár, Temeskubin (Kevevára)-Semendria települések határátkelöhelyein keresztül létesülhetett határforgalom. ${ }^{122}$ A megszállt Szerbián át, 1916 januártól a bolgár közigazgatási területen lévő Jagodinánál lehetett beutazni Bulgáriába. Polgári utasok mellett mindvégig döntő számban a katonák lépték át a határt, szabadságolásaik vagy szolgálati útjuk okán. A központi hatalmak Szerbia megszállását követően hamar helyreállították a zimonyi vasúti hidat, így ismét volt vonat-összeköttetés Magyarország és Nándorfehérvár között. Ezt követően, már 1916. januárjában útjára indult a központi hatalmakat összekapcsoló nemzetközi gyorsvonat a Balkánvonat. A Berlin-Boroszló/Breslau-Oderberg [útlevél-ellenőrzés]-Zsolna [útlevél-ellenőrzés]-, a Berlin-Drezda-Tetschen [útlevél-ellenőrzés]-Bécs, és a München-Salzburg [útlevél-ellenőrzés]-Bécs irányából érkező kocsikból a magyarországi Galántán állították össze a Balkán-félszigetre tovább induló szerelvényt. Innen útját 
Galánta-Budapest-Zimony [útlevél-ellenőrzés]-Nándorfehérvár-Jagodina [útlevél-ellen-őrzés]Szófia-[útlevél-ellenőrzés]-Konstantinápoly vonalon tette meg, illetve az ellenkező irányban is. ${ }^{123}$ (IV.sz. melléklet) Azonban a szükséges útlevél-láttamozásokon felül a Balkánvonaton történő utazáshoz be kellett szerezni az útlevéllel együtt érvényes, német-magyar-bolgár-török négynyelvü, az érintett államok hatóságai által alkalmazott egységes „,utazási engedély”-t is. ${ }^{124}$ (V.sz. melléklet) Ezen vonattal történő utazás természetesen további — az úti poggyászok mennyiségét és tartalmát meghatározó - korlátozásokat is magával vont. E gyorsvonat utasait nem csak az Osztrák-Magyar Monarchia „külső” határain, hanem a Magyar Királyság és az Osztrák Császárság közös határán is ellenőrizték és okmányaikat ennek tényét rögzítő bélyegzőlenyomattal kezelték, akárcsak a háborút megelőző években a kivándorlók esetében tették a „belső határokon”. A Balkánvonatot másfél év múlva már igen nagy arányban vették igénybe a hadseregek legénységi állományú tagjai és tisztiszolgái is, ezért a magyar honvédelmi miniszter a részükre az utazást 1917. IX. 1-jétől csak a küldő szolgálati hatóság igazolásával engedélyezte. ${ }^{125}$ Ezek ellenőrzése nemcsak a magyar-szerb határon szolgálatot lejesítő útlevélkezelökre, hanem a magyar-osztrák közös határon szolgálatot teljesítőkre is feladatot rótt.

Románia, bár több mint három évtizede csatlakozott a Német Császárság és az Osztrák-Magyar Monarchia szövetségéhez, a kiteljesedő háborúban kivárt, mivel a győztes félhez kívánt csatlakozni. A Magyar Királysággal és az Osztrák Császársággal szemben támasztott területi igényei miatt azonban 1916 nyarán titkos tárgyalásokat kezdett az antant hatalmak képviselőivel az Osztrák-Magyar Monarchia megtámadása témájában. Végül, 1916. VIII. 17-én - az elsősorban Magyarország rovására ígért területek fejében - a román kormány a francia-brit szövetség mellet kötelezte el magát és annak megfelelően 1916. VIII. 27-én este hadat üzent a bécsi és a budapesti kormányoknak. A román hadsereg alakulatai azonnal megkezdték hadműveleteiket a Kárpátok menti szorosok, határátkelőhelyek ellen. A rajtaütés során a magyar határrendőrök, csendőrök és a vámhivatalok személyzetei csak kis ellenállást tudtak kifejteni. ${ }^{126}$ Természetesen ezzel egyidőben - a beállt hadi helyzet miatt - azonnal megszünt minden polgári forgalom magyar-román határon. A román haderő hamarosan megszállta a határmenti járásokat és tovább vonult, miközben az 1. osztrák-magyar hadsereg igyekezett ezt feltartóztatni. Erdély lakosságának jelentős része - a lehetőségeihez képest - menekülni próbált a még induló vonatokon, a zsúfolttá vált utakon. A központi hatalmak sorra hadat üzentek Romániának és hamarosan ellentámadásba lendültek, így szeptember első hete után a román előretörés kifulladt, s november végére már kiszorultak Erdélyből. Az osztrák-magyar és szövetséges haderők 1917 január második hetére megszállták a korábbi Havasalföld egészét. A központi hatalmak romániai megszállását és katonai igazgatásának felállítását követően ismét lehetővé vált a Kárpátokon keresztül az erősen korlátozott és szigorú szabályok mellett engedélyezett polgári határforgalom. Természetesen a katonák határátlépése - szolgálati okból vagy szabadságolás folytán —, a szerbiai viszonylathoz hasonlóan, itt is jelentős hányadot tett ki.

A határforgalom rendőri és vámellenőrzései hatóságainak 1916 december legvégétől figyelmet kellett szentelnie a határon átlépők birtokában lévő bankjegyekre és helyettesítöire is. Ekkortól csak az 500 koronát meg nem haladó összegü pénzjegyet, csekket vagy váltót lehetett külön engedély nélkül az Osztrák-Magyar Monarchia területéről kivinni. Azonban az ezt meghaladó mennyiséghez a magyar vagy az osztrák Deviza-központ írásos engedélyét is be kellett mutatnia az utazónak. Egyúttal a 300 koronát meghaladó kereskedelmi áru kivitele nyilatkozathoz volt kötött, és külföldön történő értékesítését követően a vételárat a Deviza-központ tagjai közé tartozó intézménynél kellett beváltani. ${ }^{127}$

A magyar-szerb határon, a korábban megnyitott Zimony-Nándorfehérvár, Temeskubin (Kevevára)-Semendria határátkelőhelyek mellett, 1917 januárjának utolsó napján újonnan került kijelölésre Klenak-Šabac (Szabács) és Boljevci-Zabres a horvát-szlavónországoki Szerém vármegyében. ${ }^{128} \mathrm{E}$ Száva parti települések között komp bonyolította le a személyforgalmat.

A háború a külföldre utazók részéről - állampolgárságtól függetlenül - az utazásuk előtt, illetve külföldön tartózkodásuk alatt számos utánjárást követelt, hogy beszerezzék úti okmányukba a szükséges engedélyeket a különböző (belföldi, katonai illetve külföldi külképviseleti) hatóságoktól. Az egyes, alig néhány országot érintő utazás során a háború előtti kis méretủ vagy kevés oldalszámú okmányok hamar beteltek. A magyar határforgalom-ellenőrző hatóságok már 1916-ban bevezették azt a gyakorlatot, hogy a különböző államok betelt úti okmányait egyszerü papírból készített pótlapokkal látták el az útlevél-ellenőrzés során, hogy az átlépések további bejegyzéseit eszközölhessék. Ez elsősorban a magyar és német útlevelek esetében fordult elö. Azonban a bécsi német császári nagykövetség e szabálytalanságot jelezte és kérte az illetékes magyar hatóságokat, hogy a német okmányoknál ennek gyakorlatát szüntessék meg, mivel az útlevélszabályaik a pótlap beillesztését nem teszik lehetővé, és az azzal ellátott okmány érvénytelennek minősül. Ebből kifolyólag a magyar belügy- 
miniszter 1917 január végén utasította a Magyar Királyi Határrendőrséget, hogy közegei pótlapokat ne helyezzenek el a betelt német okmányokba, hanem az azzal átlépni szándékozókat irányítsák vissza az államának legközelebbi külképviseletére új úti okmány beszerzése végett. ${ }^{129}$ A pótlapok alkalmazása magyar útleveleknél is előfordult, de a belügyminiszter - tekintettel az általános vízumkényszerre és a gyakori hatósági bejegyzésekre - ezt csak úgy engedélyezte, ha a pótlapokhoz üres útlevéllapokat használt fel a hatóság. Az egyszerü papírlapokból készült kiegészítést ez esetben is tiltották. ${ }^{\mathbf{1 3 0}}$

A szabadságolt legénységi állományú katonák számára tilos volt - az utazás idejére szükséges mennyiséget nem számítva - élelmiszer határon történő átvitele, illetve egyenruhának, felszerelési tárgyaknak és katonai konzerveknek, a szabadságolási okmányon feltüntetteken kívül maguknál tartani. Ezek betartását a határforgalom ellenőrző hatóságok tételesen ellenőrizték és azon kincstári darabokat, amelyek birtokban tartását az okmány nem engedélyezte lefoglalták és az állományilletékes parancsnokság részére megküldték. A szabályok betartására 1917 őszén a honvédelmi miniszter külön rendeletben is felhívta a figyelmet. ${ }^{131}$

A magyar határellenőrzést végrehajtó hatóságok részére - a német császári nagykövetség felkérése alapján - a Balkán-félszigetre vagy egyáltalán keletre utazó német állampolgárok fokozottabb ellenőrzését határozták meg 1917. IX. 19-től. A német útlevélszabályok szerint a keletre utazó német állampolgároknak a Berlini Helyettes Vezérkar Útlevélközpontjánál (Passzentrale des Stellvertretenden Generalstabes in Berlin) láttamozott útlevél birtokában kellett lenniük. Az Osztrák-Magyar Monarchiában élő német állampolgárok, amennyiben délkeleti ország(ok)ba terveztek utazást, úgy az illetékes német konzulátustól kellett ehhez engedélyt kérniük. ${ }^{132}$ Ezen útlevélszabályokat általában úgy játszották ki azok, akiknek az engedély megadását megtagadták, hogy az Osztrák-Magyar Monarchiába kértek kiutazási engedélyt, majd onnan utaztak tovább. ${ }^{133}$ Ebből kifolyólag a német nagykövetség kérésére a magyar belügyminiszter elrendelte a magyar határellenőrző hatóságok részére, hogy csak - az Útlevélközpont vagy német konzulátus által - az adott keleti államba történő utazás engedélyével láttamozott útlevéllel engedélyezzék a határon történő kilépést balkáni vagy más keleti államokba. ${ }^{134}$ Ugyanezen felkérés alapján az Osztrák Császárság belügyminisztere utasította az császárság határellenőrző hatóságait, hogy ezt a gyakorlatot kövessék.

\section{Változások a magyar és az osztrák állampolgárok külföldre utazásának lehetőségében}

Az egymás ellen hadat viselő országok állampolgárainak a másik fél területére történő utazásának lehetősége - elsősorban a nők, a gyermekek és az időskorúak részére - rendkívül korlátozottan, bár elvileg lehetséges volt, értelemszerüen egy semleges országon keresztül. A frontok természetesen az átmeneti fegyvernyugvások idején sem voltak átjárhatóak polgári személyek részére. A magyar belügyminiszter az ellenséges államokba történő utazáshoz az útlevél kiállítását személyes jóváhagyásához kötötte és csak indokolt esetben, a törvényhatóság véleményezése esetén engedélyezte. ${ }^{135} \mathrm{~A}$ Magyarországon élő ellenséges hadviselő ország állampolgárainak meghatározott, hadra nem fogható köre kezdetben nagyobb, majd fokozatosan korlátozott mértékben, de szabadon élhetett. Azonban külföldre utazásuk már csak az Osztrák-Magyar Monarchia kormányai által engedélyezett és szervezett módon, és általában végleges jelleggel történhetett.

Szerbián kívül, 1914. augusztusa folyamán - a beálló hadiállapot miatt - megszünt a magyar és az osztrák állampolgárok beutazása Montenegróba (1914. VIII. 5-től), Oroszországba (1914. VIII. 6-tól), az Egyesült Királyságba (1914. VIII. 12-től), Franciaországba (1914. VIII. 13-tól), Belgiumba (1914. VIII. 22-től), és Japánba (1914. VIII. 25-tól). A következő nyolc hónap az Osztrák-Magyar Monarchia ellenében újabb hadba lépést nem hozott.

Az olasz kormány már 1914. IX. 15-ével elrendelte, hogy az Olaszországba beutazó külföldiek csak olasz külképviselet által láttamozott útlevél birtokában léphetnek be. ${ }^{136}$ Ezzel ezen európai állam lett az első, amely a háború miatt (újra) bevezette a vízumkényszert. A német hadsereg által, rövid idő alatt megszállt Belgium Antwerpen városába, a korábban ott élő magyar és osztrák állampolgárok részére, a német kormány 1914. novemberének második felétől lehetővé tette a visszatérést. Ennek feltétele volt, hogy az említett személyek útlevéllel és benne az illetékes német császári konzulátus Belgiumba érvénnyel bíró láttamozásával rendelkeztek. Egyéb belga településre, illetve korábban nem ott élőknek a német külügyminisztérium engedélye is szükséges volt, amelyért csak kellően megindokolt kérvény útján lehetett folyamodni. ${ }^{137}$ A háború során a megszálló államok kormányzatának döntése alapján általában tovább ellenőrizték a korábbi államhatáron az általuk megszállt területekre utazók forgalmát, illetve az onnan visszafelé közlekedőket. A semlegességét majd mindvégig megtartani képes holland kormány decemberében hozott intézkedést, amellyel bevezette az általános útlevél- illetve vízumkötelezettséget. ${ }^{138}$ 
A német kormány 1915. I. 1-jétől rendelte el, hogy Németország államhatárain csak akkor léptethetőek át az utazók, ha útleveleik csatolt fényképpel vannak ellátva, továbbá a beutazó külföldiek esetében a német konzulátusok láttamozása is szükséges volt. ${ }^{139}$ A központi hatalmakkal elvileg még szövetségben álló Románia a háború kitörése előtt az államhatárain átlépőktől csak útlevelet követelt meg, illetve, amelyeket olyan településen állítottak ki, ahol román konzulátus müködött, akkor ebben az esetben annak láttamozása is szükséges volt. ${ }^{140}$ A román kormány 1915 márciusától azonban — kiállítási helytől és állampolgárságtól függetlenül —minden külföldi útlevél előzetes láttamozását megkövetelte. ${ }^{141}$ A magát 1915 nyarának végére Német Császárság és az Osztrák-Magyar Monarchia oldalán elkötelező Bulgária kormánya, 1915. szeptemberétől csak azon külföldiek részére engedélyezte a beutazást, akik útlevele fényképpel volt ellátva, és amelyeket egy bolgár konzulátus láttamozott is. ${ }^{142}$

A külföldre utazás a háború első évét követően az Osztrák-Magyar Monarchiával szövetséges és a semleges államokra korlátozódott, azonban a mind újabb hadba lépö országok miatt tovább szükültek a lehetőségek. Az Osztrák Császárság és a Magyar Királyság állampolgárinak 1915. V. 23-án - az olasz kormány hadüzenetével - megszünt az Olaszországba történő utazás lehetősége, bár a San Marinói Köztársaság semleges maradt a háború idején is, azonban oda csak az olasz állam területén át volt lehetőség utazni. Ezáltal a magyar és osztrák állampolgárok semleges kikötőkből tengeren túlra csak Hollandiából és Dániából, valamint Svédországból illetve Norvégiából utazhattak. Az elvileg semleges Görögország északi területein 1915 végétől jelentős antant haderő állomásozott.

A magyar állampolgároknak és a Magyarországon élő külföldieknek, Svájcból vagy Romániából az Osztrák-Magyar Monarchiába történő hazatérését 1915. XI. 13-tól azon esetben engedélyezték, ha útleveleikben rendelkeztek visszautazásra érvényes záradékkal is. Amennyiben ennek híján voltak, úgy az illetékes Osztrák-Magyar Monarchia konzuli hatóságnál ezt be kellett szerezniük. Svájc és Románia - utóbbi a semlegessége fenntartásáig - határosak voltak a központi és az antant hatalmak államaival is, azonban más államokba az átutazás nem volt lehetséges. (VI.sz. melléklet) Ez akár lehetőséget is adott a két ellenfél állampolgárainak a találkozására vagy az ellenséges fél területére történő utazásra is. Ez utóbbi lehetőséget a semleges országok állampolgárai igénybe is vették a hadban álló területek közötti utazáshoz. Az új szabályozás lehetőséget adott arra, hogy a két semleges országba utazók tartózkodásának tényleges célját, okát és időtartamát a hazatérés előtt a külképviseletek megvizsgálhassák, és az esetleges államellenes tevékenység gyanúját megfogalmazhassák. Az Osztrák Császárság és Magyar Királyság állampolgárainak a Svájcba utazáshoz - mivel az törvényszerủen a nyugati osztrák tartományokon keresztül vezetett - a külső hadmüveleti területekre történő utazást is engedélyező láttamozást be kellett szerezni. (VII.sz. melléklet) Bár majd 1917. XII. 15-vel a délnyugati front osztrák külső és belső hadmüveleti területeit jelentősen lecsökkentették ugyan, azonban az osztrák-svájci határt átlépni szándékozóknak mindenképpen át kellett utaznia Vorarlbergen, amely továbbra is külső hadmüveleti terület maradt. ${ }^{143}$ A Svájcba utazóknak a szükséges engedélyeket továbbra is előzetesen kellett beszerezniük. E módosítás a Salzburgon vagy Innsbruckon keresztül Németországba utazóknak jelentett segítséget.

A magyarországi útlevél-kiállítás - ide érve a horvát-szalvónországokit is - mennyisége a háború kitörését követően jelentősen csökkent, különösen a kivándorlók részére kiadott okmányok száma esett vissza. Míg 1914-ben az összesen 156774 útlevélből 104393 darabot (66,6 \%) kivándorlók számára állítottak ki, addig az 1915. évben már csak 17976 úti okmányt adtak ki, amiből csak 2702 jogosított kivándorlásra $(15,0 \%)$. Természetesen a korszak útlevelei a jogosult családtagjának is utazási jogot biztosíthatott a megfelelö rovatok hatósági megszemélyesítése révén, így a kiadott útlevelek számánál több személy utazhatott. Ebből adódóan a jogosultak számának vizsgálata pontosabb képet ad. Így 1914-ben 131520 fő volt kivándorlásra jogosult, 1915-ben már csak 4372 magyar állampolgár, vagyis ezen adatban a visszaesés 96,7 \%-os volt. Az utazási körülmények megváltozása miatt a kivándorlóknak nemcsak száma, hanem úti célja is megváltozott, míg 1914-ben még 76,6 \%-uk az Amerikai Egyesült Államokba és 15,8 \%-uk Romániába utazott, addig a következő évben e két célország arányszáma 52,8 \%-ra és 41,8-ra változott. Természetesen a kiállított útlevelekre jogosultak számánál kisebb volt a ténylegesen távozók száma, ez 1915-ben és elötte is 70-75\% között mozgott. A hadköteles férfiakat érintő úti okmány korlátozás jelentősen megváltoztatta a ténylegesen kivándorlók nemének arányát is. E szerint 1913-ban a kivándorlók 47,9 \%-a volt férfi — ami egy évtized során az egyetlen alkalom volt, hogy $50 \%$ alatt maradt, ami a Balkán-háborúk miatt a férfilakossággal szemben bevezetett magyarországi korlátozó intézkedések eredménye volt-, 1914-ben 66,1 \%-a, míg 1915-ben már csak 32,1 \%-a. ${ }^{144}$ A háború későbbi éveiben az arányok mindvégig a nők részéről mutattak nagyobb mértéket. 
Az Osztrák-Magyar Monarchia hadserege a háború során a megszállt területek felett átvette a közigazgatást, valamint - elsősorban katonai szempontokat alapul véve - a nem hadmüveleti célú határforgalom ellenőrzését és a megszállt területekre történő beutazás szabályozását is. A keleti fronton a német és az osztrák-magyar haderők Oroszország Lengyel Főkormányzóságának jelentősebb területe felett vették át az ellenőrzést. Az osztrák-magyar katonai közigazgatás alatt álló területekre történő utazáshoz a hadsereg-föparancsnok 1915. II. 15-én kiadott rendelete alapján megfelelő fényképpel s sajátkezü aláírással ellátott olyan útlevél felmutatása vált szükségessé, melyet kifejezetten a megszállt területekre állítottak ki, melyben továbbá az utazás célja és végpontja pontosan fel volt tüntetve és mely végül a hadsereg-főparancsnokság (hadtáp-föparancsnokság) vagy a hadügyminisztérium láttamozásával van ellátva. ${ }^{145}$ A szükséges láttamozásokat a kezdeti időszakban csak a hadsereg-föparancsnokság és a hadtáp-főparancsnokság székhelyén lehetett kérelmezni, azonban ez gyakorta jelentős akadályokat okozott - a kitérők és időveszteség miatt - a kereskedőknek és az utazóknak is, ezért 1915. nyarának végén katonai útlevél-láttamozó kirendeltséget létesítettek a fö közlekedési útvonalaknak határközeli két településén, a galíciai Krakkóban és az orosz-lengyelországi Granicában. ${ }^{146}$ A granicai hivatalt 1915. októberének első napjától - a szomszédos, de még Galíciában lévő - Szczakowába helyezték át, ahol jelentős vasúti csomópont volt. ${ }^{147}$ Az utazási szabályokat 1915. december közepén a belügyminiszter újabb rendeletben összefoglalta. Ez már lehetőséget biztosított a megszállt OroszLengyelország területére történő utazás esetén az útlevél mellett az arcképes igazoló jegy használatára is, amennyiben ezeket az elsőfokú hatóság a megfelelő magyar és német nyelvủ záradékkal ellátta, a katonai láttamozás továbbra is szükséges volt. ${ }^{148}$ Ekkortól újabb útlevél-láttamozó kirendeltségek is felállításra kerültek, nevezetesen az említett Krakkó és Szczakowa mellett Lembergben (Lwów) és Rozwadówban is. ${ }^{149}$ Orosz-Lengyelország osztrák-magyar hadsereg által tartósan megszállt területén kiépült a katonai közigazgatás, amelyet a Lublini Császári és Királyi Főkormányzóság irányított. A lengyelországi hadszíntér elhelyezkedése 1915. és 1917. között több ízben is jelentősebb mértékben módosult, ilyenkor az érintett megszállt területekre és az onnan történő utazás szigorúbb ellenőrzése történt meg, miközben a menekülők részére meghatározott engedmények voltak tehettek. Újabb útlevélláttamozó kirendeltség nyílt 1916. végéig Tarnówban, és 1917. elején a szczakowait Granicába helyezték vissza. A szükséges katonai láttamozás már a határ átlépése során is beszerezhető volt. ${ }^{150}$ Szerbia 1915. öszén történt megszállását követően az év utolsó heteiben kiépült a katonai közigazgatás, amelyet fökormányzóság útján irányítottak. A megszállt terület egészére vagy azon keresztül történő utazást 1915. legvégén az úgynevezett Mackensen-hadseregcsoport föparancsnoksága engedélyezte, egyes, meghatározott körzetek területére a kijelölt magasabbegységek parancsnokságai is kiadhattak engedélyt. ${ }^{151}$ Azonban már 1916. január elején e jogkörök mindegyikét a Szerbiai Osztrák-Magyar Katonai Főkormányzósághoz rendelték. ${ }^{152}$

Természetesen a külföldre utazáshoz szükséges pénz előteremtése is egyre több gondot okozott az utazni szándékozónak, hiszen a bérek értéke a háború elöre haladtával csökkent, az árak lassan emelkedtek, a hiánycikkeké pedig akár meg is többszöröződhetett a feketepiacon. Ezen túlmenően az Osztrák-Magyar Monarchiával szövetséges és semleges államok valutáira történő átváltási aránya is romlott a háborús évek múlásával. A háború előtti és az 1916. évi árfolyamok tekintetében nagyjából már 30-35 \%-os értékvesztés történt. ${ }^{153}$ Ezáltal a külföldre utazás adminisztratív és fizikális akadályai mellé mind erőteljesebben jelentkeztek az anyagi nehézségek is. Mindezek mellett a közlekedési lehetőségek is korlátozottak voltak, a vasúti összeköttetés jelentősen változott, a személyszállításban a polgári lakosság igényeinek teljesítését megelőzte a csapat- és hadi szállítások jelentősége.

A külföldre történő utazás lehetősége 1916-ban tovább csökkent, a Portugáliával beálló hadi állapot miatt 1916. III. 15-től, majd Romániával 1916. VIII. 27-től szünt meg a polgári személyforgalom. A török kormány - amely még 1914. előtt is szigorú beutazási szabályokat foganatosított - tovább szigorította a vízumkérelmezés menetét. A kérelemhez csatolni kellett az útlevélben szereplő képmással azonos fényképet, továbbá erkölcsi bizonyítványt, valamint az útlevélkérelmet átvevő hatóság igazolását is, amely rögzítette az utazás célját, és annak a személynek a megnevezését, akivel a beutazni szándékozó Törökországban kapcsolatba kívánt lépni. ${ }^{154}$ Ezt 1917 márciusában a török hatóságok tovább szigorították azzal, hogy a kérelemhez négy darab azonos fényképet kellett csatolni. ${ }^{155} \mathrm{Az}$ egymással szövetségben álló központi hatalmak igyekeztek egymás állampolgárait is szigorúbb ellenőrzés alá vonni, utazásukat csak indokolt esetben engedélyezték.

A német kormány 1916 tavaszára akként szigorította a területére beutazni szándékozókra vonatkozó szabályokat, hogy az útlevélre jogosult családtagjai közül a feleségnek már külön, az elöírtaknak megfelelő útlevéllel és vízummal kellett rendelkeznie. A gyermekek továbbra is bejegyezhetőek maradtak a szülő útlevelében, amennyiben a nevén kívül legalább a korát is jelölték. Ezzel egyidő- 
ben a tényleges katonai szolgálatban állók részére a német kormány lehetővé tette a meghatározott osztrák-magyar illetékes parancsnokságok, illetve a magyar honvédelmi minisztérium által németül is kiállított, az utazó hitelesített aláírását is tartalmazó utazási okmánnyal - nyílt paranccsal, menetlevéllel, szabadságolási engedéllyel - való belépést is, szolgálati vagy rövid idejű magánügyben. ${ }^{\mathbf{1 5 6}}$

Az Osztrák-Magyar Monarchia ellen irányuló 1916. évi román hátbatámadást követően a központi hatalmak csapatai hamarosan felvették a benyomulókkal a harcot, és októberre sikeresen kiszorították őket Magyarországról. Már 1917 január második hetében megszállták Havasalföldet, majd a kiépülő katonai közigazgatás idővel lehetővé tette polgári személyek ide történő utazását is. A romániai front 1917 januárjában állóháborúvá vált Moldovában, s itt a harcok tovább folytak. A megszállt román területekre már 1917. január végén különösen méltányolható esetekben utazni lehetett, bár csak érvényes útlevél vagy arcképes igazoló jegy, valamint a bukaresti katonai kormányzóság császári és királyi meghatalmazottjának engedélyével. ${ }^{157}$ Ezzel egyidőben megszünt a határmenti területek lakossága részére, a kishatárforgalomban közlekedőknek, korábban biztosított okmánykedvezmény, a korábbi átkelési igazolvány, a szelvényes külföldi úti igazolvány vagy a határszéli közlekedési igazolvány ${ }^{158}$ már nem volt elfogadható úti okmány a határátlépés során. Mialatt Románia Moldva határterületein továbbra is harcok folytak 1917 február első napjaiban felmerült annak lehetősége, hogy a Romániában rendőri felügyelet illetve őrizet (internálás) alatt álló osztrák és magyar állampolgárok, és az Osztrák-Magyar Monarchiából a román állampolgárok meghatározott körét hazaengedjék. ${ }^{159}$ Azonban a román hatóságok az Osztrák-Magyar Monarchia állampolgárait az emberiesség követelményeivel össze nem egyeztethető bánásmódban részesítették az örizet idején és többen emiatt meg is haltak. ${ }^{\mathbf{1 6 0}}$ A közös külügyminisztérium felhívására a román kormány nem tett kedvező intézkedést, így Magyarországon szigorúbb ellenszabályokat vezettek be. A magyar hatóságok részére már 1917. II. 16-án elrendelték, hogy minden, 17 és 55 év közötti, addig csak rendőri felügyelet álló román állampolgárságú férfit állítsanak elő, akiket a Tápiósülyön lévő internálótáborba gyüjtöttek össze. ${ }^{161}$ Csak 1918 januárjában engedték haza a román állampolgárok jelentős részét. A magyar belügyminiszter 1917 júliusának elején hirdette ki a Dél-Romániába történő utazás feltételeit, amely szerint az ehhez szükséges kérvényt a bukaresti meghatalmazotthoz az elsőfokú rendőrhatóság vagy - üzleti út esetén - a Magyar Királyi Kereskedelmi Minisztériumon, illetve a Magyar Királyi Honvédelmi Minisztériumon keresztül kellett megküldeni. A határátlépéshez az engedélyen kívül természetesen szükség volt a Románia megszállt területére is érvényes útlevélre vagy igazolójegyre is, amelyet az elsőfokú rendőrhatóság vagy Magyar Királyi Kereskedelmi Minisztérium záradékolt a kérvény leadásakor. ${ }^{162} 1917$ szeptember közepén a rendelkezés annyival egészült ki, hogy szabvány formanyomtatványt vezettek be a kérelmezéshez, ahol az elsőfokú hatóság feljegyezte a bemutatott úti okmány számát is. Ezen túlmenően, minden kérelmet az elsőfokú rendőrhatóságnál kellett leadni, amelyet üzleti út esetén a Magyar Királyi Kereskedelmi Minisztériumon keresztül, egyéb cél megjelölésekor közvetlenül a császári és királyi meghatalmazotthoz véleményezéssel együtt továbbíott. ${ }^{163}$ Orosz-Lengyelországnak a német csapatok által megszállt és igazgatott területére történő utazás - fényképpel és annak záradékával ellátott - Németországba érvényes útlevél és a varsói német fökormányzóság külön engedélye birtokában volt lehetséges. A jóváhagyását az említett német hatóság útlevélosztálya csak rendkívül indokolt esetekben adta meg, és az illetékes magyar szakminisztérium közbenjárására is szükség volt. ${ }^{164} \mathrm{~A}$ román csapatok végül - amikor az orosz bolsevik kormány kilépett a háborúból - 1917 december elején letették a fegyvert, majd 1918. V. 5-én békét kötött Románia a központi hatalmakkal és szövetségeseivel. Románia akkortól ismét semleges állammá vált, s majd csak a háború utolsó napjaiban üzent ismét hadat, amikor az Osztrák-Magyar Monarchia már fegyverszünetet kötött.

Délkelet-Európa nagyobb területein 1917 elejére beállott nyugalmi időszak hatására az ott megszállt országokba történő utazás is engedélyezett volt a rendszabályok betartása mellett. Így Romániának, Szerbiának, Albániának és Montenegrónak a központi hatalmak által megszállt területeire az oda kifejezetten érvényes hatósági záradék megléte esetén útlevéllel vagy arcképes igazoló jeggyel - méltányolhatóan indokolt esetben - utazni lehetett. ${ }^{165}$ Ennek megfelelően 1917 februárjától a nándorfehérvárii kormányzóságba érvényes engedélyt már a nándorfehérvári útlevél-kirendeltség, a többi kerületbe a niši bolgár katonai kormányzóság vagy a bolgár kormány adta ki. Albánia és Montenegró területére, az említett időtől kezdődően a scutari-i illetve a cetinjei útlevél-kirendeltség engedélyére is szükség volt. ${ }^{166}$

A külföldre történő utazás részben elvi lehetősége 1917-ben tovább szükült. A júliusban beálló hadi állapot miatt Görögországba (1917. VII. 2-tól), Kínába (1917. VII. 14-töl) és Sziámba (1917. VII. 22-től) nem utazhattak a Magyar Királyság és az Osztrák Császárság állampolgárai. 1917 decemberében az Amerikai Egyesült Államok (1917. XII. 7-én), Panama (1917. XII. 10-én) és Kuba (1917. 
XII. 16-án) határainak átlépése vált lehetetlenné az Osztrák Magyar Monarchia mindkét országának állampolgárai részére. Végül, utolsóként Nicaragua üzent hadat az Osztrák-Magyar Monarchiának 1918. V. 18-án. Természetesen az ázsiai államok határait a háborús idők kezdetétől, a korábbinál is alacsonyabb számban lépték át a magyar és az osztrák állampolgárok.

Azon magyar férfi állampolgárok, akik állandó jelleggel Németországban éltek és a hadi szolgálatra alkalmatlanok voltak, az Osztrák-Magyar Monarchia területéről visszautazásuk során 1917. XII. 1-jétől átléphették a határt az - útlevélpótló úti okmányként ekkortól elismert - illetékes katonai hatóság által kiállított, záradékolt és fényképpel ellátott honvéd vagy népfelkelési igazolványi lappal is. ${ }^{167}$

Miután 1917 decemberében Vorarlberg kivételével megszüntették az osztrák külső hadműveleti területeket, a magyar kormány 1918. I. 25-évél ugyanezt tette, csak Háromszék és Csík vármegyék illetve Fiume kerületében maradt meg továbbra is a belső hadműveleti terület intézménye. ${ }^{\mathbf{1 6 8}}$ Ezáltal a déli és délkeleti magyar határon történő átlépéshez - az említett három közigazgatási egységet ide nem sorolva - már nem kellett a belföldi területre külön engedélyező záradék, elegendő volt az utazás szerint érintett megszállt terület illetve szövetséges állam illetékes hatóságától át- vagy beutazási vízumot beszerezni. Háromszék és Csík vármegyékbe és annak - romániai viszonylatú - határátkelőhelyein történő átutazáshoz a brassói katonai útlevélhivatal engedélye is szükséges volt. ${ }^{169}$

A keleti front az oroszországi események miatt 1917. végén orosz részről már nehezen volt tartható, így a bolsevik kormány fegyverszünetet kért. A központi hatalmak 1917 decemberében elönyös helyzetben kezdték meg a béketárgyalásokat Oroszországgal - mialatt Finnország elnyerte függetlenségét -, amelyek 1918. III. 3-án a breszt-litovszki békéhez vezettek. Ezt követően hamarosan létrejöhetett az Oroszországtól ténylegesen független Ukrajna is. Az így semleges állammá váló Oroszországba és Ukrajnába azonban kizárólag gazdasági okokból engedélyezték az osztrák és magyar állampolgárságú polgári személyeknek az utazást, amelyet az Osztrák-Magyar Monarchia Hadsereg-fóparancsnoksága engedélyezett. Az orosz és ukrán hatóságok 1918 öszének elején még továbbra sem követelték meg az útlevelek előzetes láttamozását, azaz vízummal történő ellátását. A magyar katonák szabadságukat az itt tárgyalt két országban csak rendkívül indokolt esetben, a honvédelmi miniszter külön engedélyével tölthették, és az útlevél-kötelezettség alól sem mentesültek, amely beszerzéséröl a miniszter kedvező döntés esetén maga intézkedett a magyar belügyminiszternél. ${ }^{170}$

Az észak- és közép-európai semleges országokba történő utazás újabb korlátozásáról 1917 első harmadában léptettek életbe újabb rendelkezéseket. ${ }^{171} \mathrm{~A}$ semleges államokba, azaz Dániába, Hollandiába, Norvégiába, Svájcba és Svédországba utazóknak kötelezővé tették a korábbi rendelkezések érintetlenül hagyása mellett, hogy útlevelüket az innsbrucki térparancsnokságnál illetve az Osztrák Magyar Monarchia illetékes ellenőrző hatóságnál láttamoztassák. A külföldieknek — akiknek az úti okmányát külképviseletük Magyarországon állította ki — az illetékes rendőrhatóság láttamozása is szükséges volt. Ekkortól az Osztrák-Magyar Monarchia területéről az érintett országokba csak a kijelölt határátkelőhelyeken át lehetett utazni (VIII. sz. melléklet), ettől kezdődően Svájcba - a német állampolgárokat kivéve - csak Feldkirch határátkelöhelyen léphették át az államhatárt. Svájcba Németországon át nem volt engedélyezve az utazás, kivéve, akik már 1914 augusztusa elött is a Német Császárságban éltek. A semleges államokba utazó minden állampolgárnak - akik a tételesen meghatározott kivétel alá nem estek - 10 napi vesztegzárat kellett letölteniük a meghatározott települések egyikén, amelyröl az illetékes rendőrhatóság igazolást állított ki.

Speciális viszony füzte össze az Osztrák Császárságot és Lichtensteint, amely a hadban álló Osztrák-Magyar Monarchia és Lichtenstein közötti határforgalom jellegét is befolyásolta 1914 és 1918 között. Liechtenstein az HABSBURG-birodalommal 1852-től, posta-, pénz-, adó- és vámügyi szerződések révén egységes területet alkotott. ${ }^{172}$ Ezen állapot 1914-ben továbbra is fennállt. A liechtensteini-svájci határ vámellenőrzését osztrák vámhivatal és kirendelt személyzete hajtotta végre.

Az Ausztria és Svájc közé ékelt Liechtenstein a háborúban a semlegességet választotta, amely mellett mindvégig kitartott. Azonban a semlegesség fenntartására már 1914. augusztus elején önkéntes, fegyveres határôr csoportok felállítását rendelték el Liechtenstein svájci határa mentén fekvő településeken. ${ }^{173}$ A magyarországi szabályozással egyidőben, 1915. I. 20-tól, és azzal összhangban az osztrák kormány is bevezette a külső államhatárokon átlépőkkel szemben az általános útlevél- és vízumkényszert. Annak ellenére, hogy az Osztrák-Magyar Monarchia vámunióban volt Liechtensteinnel ekkortól kezdődően, ,ideiglenes” jelleggel bevezették az útlevélkényszert és kijelölték a közös határ mentén az átlépésére szolgáló kizárólagos útvonalakat is. ${ }^{174} \mathrm{Az} 1915$. I. 31-éig terjedő átmeneti időszakban a helyi határforgalom-ellenőrző hatóság, az osztrák katonai parancsnoksággal egyetértésben egyéb okmányt is elfogadhatott a határátlépőktől. A liechtensteini állampolgárok útlevelének is kötelezően, hivatalosan záradékolva csatolt fényképet kellett tartalmaznia, azonban a osztrák-ma- 
gyar külképviseletek előzetes láttamozása alól mindvégig mentesültek. ${ }^{175}$ Ezen rendelkezés által kizárólag e hercegség útlevelei voltak vízummentes külföldi okmányok a háború idején. Liechtensteinböl Ausztriába történő utazás esetén, 1915 szeptemberétől a belépő személyek az Osztrák-Magyar Monarchia külső hadmüveleti területére léptek, így fokozottabb ellenőrzésnek voltak kitéve ezt követően. ${ }^{176}$

Svájc a liechtensteini határán már 1914. VIII. 20-án elrendelte az államhatár átlépésének tilalmát este 10 és hajnali 5 óra között, amely alól csak kivételes esetekben, meghatározott személyeknek adtak kivételt. ${ }^{177} \mathrm{Az}$ említett szakaszon majd 1915. október végén vezette be a svájci kormány az általános útlevél-kötelezettséget és határforgalom ellenőrzést, egyúttal kijelölve az átlépéskor használható utakat és a tilalmi időszakokat is. ${ }^{178}$

Az Osztrák-Magyar Monarchia és Liechtenstein közös vámterület 1919. szeptemberéig állt fenn, amikor az osztrák kormányzat felmondta az 1852-ben kötött megállapodást. Liechtenstein végül 1923ban Svájccal kötött — a korábbi osztrák egyezményhez hasonló — szerződést, amely máig fennáll.

\section{Idegenrendészet Magyarországon, 1914-1918}

Az 1910-ben tartott országos népszámlálás alapján 278130 fő külföldi élt a Magyar Szent Korona országaiban, ebből 201924 fö a Drávától északra (ez 13 \%-os növekedés volt az 1900. évi adatokhoz képest). Természetesen külföldinek tekintették ezen adatban az osztrák állampolgárokat és a boszniai illetőségüeket is, különösen elöbbiek tették ki a döntő hányadot. ${ }^{179}$ Budapesten, a nem magyar állampolgárok száma a tíz évvel azelőttihez képest, csekély csökkenés mellett 1910-ben 44102 fö, Fiumében pedig növekedést követően 19836 fö volt. ${ }^{\mathbf{1 8 0}}$

Már a háborút megelőző hónapokban mind alaposabb, körültekintőbb ellenőrzésnek vetették alá a külföldiek tartózkodását Magyarországon és vizsgálták azt sok osztrák állampolgárnál is, bár a korábbiaknál szigorúbb rendelkezést nem vezettek be. Ennek következtében mind gyakoribbá váltak az ország egész területéröl történő kitiltások. Egyre gyakrabban nem csak a leendő ellenséges államok polgárait, hanem számos szövetséges, sőt osztrák állampolgárt is magyarországi beutazási és tartózkodási tilalom hatálya alá helyezték. ${ }^{181}$ A kitiltás alapjául több esetben az 1903. évi külföldiek tartózkodásáról szóló törvény ide vonatkozó részét nevezték meg: „az a külföldi, a ki magát kellően nem igazolja, a maga és családja fenntartására szolgáló eszközöket ki nem mutatja, vagy a kinek az állam területén való tartózkodása az állam érdekeire, vagy a közbiztonságra és a közrendre nézve aggályos; az állam területéröl a rendőri hatóság által bármikor kiutasítható, esetleg kényszer útján is eltávolítható". ${ }^{182}$

Az első háborús hetek meghozták a külföldiek fokozottabb ellenőrzésének igényét és időszakát is. Ennek előfeltétele volt, hogy az addigi útlevélkényszertől mentes külföldieknek személyazonosságukat igazoló úti okmányt kellett beszerezniük az államuk szerinti külképviseleten. Az Amerikai Egyesült Államok állampolgárai részére - külképviseleteik által útlevéllel történő ellátásukig - ha a tartózkodási helyük szerinti illetékes hatóság elött állampolgárságukat elfogadható módon igazolni tudták, akkor a legközelebbi konzuli képviseletükig ${ }^{183}$ szabad utazást élveztek a magyar belügyminiszter 1914. IX. 18-án kelt körrendelete értelmében. ${ }^{184}$ Hasonló szabályozás élt ekkor az Amerikai Egyesült Államokbeli állampolgárokkal kapcsolatban az Osztrák Császárságban is. Bár ekkor még nem volt kötelező Magyarországon a személyazonosító okmány birtoklása, azonban az angolul beszélö nemzetek állampolgárait értelemszerúen meg kellett különböztetnie a magyar és az osztrák hatóságoknak is. Általános úti okmány kötelezettség bevezetésére azonban a következő közel négy hónap során még nem került sor. Magyarország területén tartózkodó valamennyi külföldit 1915. I. 20-tól kötelezték, hogy fényképpel és hatósági záradékkal ellátott útlevéllel rendelkezzenek. E szabály alól csak az osztrák állampolgárok és a bosznia-hercegovinai illetőségúek kaptak felmentést, amely a háború időtartamában nem változott. ${ }^{185}$

Az egymással hadban álló országokban hátramaradt ellenséges állampolgároknak továbbra is szükségük volt konzuli képviseletre - például hagyatéki vagy peres ügyek intézése miatt -, amellyel mindig egy semleges állam került megbízásra. Ezek illetékességét a fogadó hadviselö fél is tiszteletben tartotta, mivel maga is hasonlóképpen cselekedett a megbízó államban. Így az 1914. júliusi és augusztusi hadüzeneteket követően Magyarország területén a szerb és az orosz állampolgárok konzuli képviseletét az Amerikai Egyesült Államok budapesti fökonzulátusa vette át. ${ }^{186}$ Az Osztrák-Magyar Monarchiával szemben hadviselő országok rendőri örizet (internálás) alatt nem álló állampolgárainak országos összeírását majd csak 1914 november közepén rendelték el. ${ }^{187}$ Ez hamarosan lehetővé tette a kölcsönös hazabocsátás megszervezését is, amely során nyilatkozni kellett a hazatérés vagy a maradás mellett is. ${ }^{188}$ Eddig az ideig a legtöbb ellenséges állam honosa rendes polgári életmódjában és foglal- 
kozásában zavartalanul megmaradhatott. ${ }^{189}$ A külföldieknek újabb, 1915 áprilisában elrendelt nyílvántartásba vételét követően az ellenséges államok állampolgárait rendőrhatósági felügyelet alá helyezték, amely a személyes szabadságnak bizonyos korlátok közé szorítását (például lakhelyelhagyás tilalmát, kapcsolattartás engedélyhez kötését, stb.) jelentette a legtöbb esetben, de a katonakorú férfiak összegyüjtését is elrendelhették ez alapján. ${ }^{190}$ A külföldiek tartózkodásával kapcsolatos szabályok 1915 augusztusában tovább szigorodtak. E szerint az útlevél-kötelezettség alá eső állampolgárok - az osztrákokat és a németeket kivéve - a legrövidebb idejü tartózkodást is kötelesek voltak bejelenteni, $\mathrm{s}$ távozási szándékukat elöre jelezniük kellett, az illetékes hatóság e tényt az útlevélbe be is jegyezte. ${ }^{191}$ A Magyarországon tartózkodó külföldieknek 1915. XI. 13-tól, amennyiben útlevelüket a Magyar Szent Korona országainak területén székelő konzuli hatóságuk állította ki, akkor az illetékes rendőrhatóság által azokat láttamoztatni kellett. Ugyanekkortól, az esetleges kiutazásukat követően, a Svájc vagy Románia felöl visszaérkezés esetén, visszautazási záradékot is be kellett szerezniük, ha csak azt korábban nem kapták meg.

A külső és a belső hadmüveleti területre utazó minden személy, állampolgárságtól függetlenül a meghatározott utazási okmányok és engedélyek birtokában kellett lennie 1915 szeptember havától. Magyarország (illetve Ausztria) külső és belső hadműveleti területeire történő utazáshoz 1915 decemberétől az Osztrák-Magyar Monarchiával szövetséges államok és a semleges országok állampolgárainak arcképpel és sajátkezü aláírással ellátott útlevelei is érvényesek voltak, amennyiben az adott hadműveleti területre érvényes záradékot beszerezték az illetékes hatóságtól. Az engedély azonban kizárólag akkor volt megadható, ha az illető külföldinek megbízhatósága kétségtelenül igazoltnak látszott. ${ }^{{ }^{192}}$

A Magyarországon legalább néhány napot tartózkodó külföldinek - a határátlépés feltételeinek teljesítését követően - a háborús gazdaság okozta szükösségekkel is szembe kellett néznie. Az elhúzódó háborúra berendezkedő Magyarországon 1915 novemberének közepén bevezetésre kerül a tejjegy, majd 1916. I. 10-től a liszt- illetve kenyérjegy is, utóbbi Bécsben és Alsó-Ausztria tartományban már 1915 április közepén bevezetésre került. A vendéglátó egységek a jegyrendszerbe bevont élelmet csak a jegyek ellenében szolgálhattak fel. ${ }^{193}$ A fokozódó ellátási gondok miatt a cukor kereskedelmének korlátozására 1916 márciusában, míg a kenyérfejadagok csökkentésére egy évvel később, 1917 tavaszának elején került sor. Ezek a megszorítások természetesen érintették a nem átutazás céljából érkező külföldieket is.

A külföldi államok diplomatáinak és feleségeik részére már a háború kitörése előtt az osztrák-magyar császári és királyi Külügyminisztérium úgynevezett igazoló jegyeket („Legitimationskarte”), azaz a diplomáciai testülethez való tartozásukat elismerő iratot állított ki, amely egyúttal fegyvertartási és vadászigazolványként is szolgált. ${ }^{194}$ Ezen okmány német egynyelvü volt és a kiállítástól számítva egy évig bírt érvénnyel. E korábbi igazoló jegy helyett a császári és királyi Külügyminisztérium 1916 februárjától új külalakkal, és immáron német-magyar nyelven nyomtatott ürlapok kiállítását kezdte meg, szintén egy éves érvényességgel és az továbbra is jogosított fegyvertartásra és vadászatra is! A korábban kiadott igazoló jegyek azonban 1916. IV. 1-jén hatályukat vesztették. A rendőrhatóságok kellő tájékoztatása végett a közös külügyminisztérium, a magyar belügyminiszter útján mintapéldányokat juttatott el az illetékes hatóságokhoz 1915 januárjában a korábbi, 1916 januárjában az újabb változatból. ${ }^{195}$

A háború már az első hónapokban igen sok áldozatot követelt. Azonban különösen a kezdeti idöszakban az egymással hadviselő felek a kölcsönösség elvén lehetővé tették, hogy a másiknak veszélyt nem jelentő állampolgárait - gyermekek, nők, idős férfiak - akik gyanú alatt nem álltak, elsősorban felügyelet mellett hazaengedjék. Az Osztrák-Magyar Monarchia területének elhagyása általában valamelyik osztrák tartomány határátkelőjénél, a semleges Svájcon keresztül történt, azonban a szerbeket az egyszerüség okán - Románián keresztül utaztatták ki. Ez biztonságos hazatérést jelentett a harci cselekmények szüneteltetése nélkül is. Az elutazni szándékozók adatait, az egy-egy állampolgári kör részére történő engedélyezés kiadását követően, az alispánnak illetve az elöljárónak jegyzékbe kellett gyüjtenie és azt haladéktalanul továbbítani kellett a belügyminiszter részére. A legtöbb esetben a hazatérők Budapesten keresztül voltak kötelesek a kijelölt határátkelőhelyekre utazni, és szabályos útlevéllel kellett rendelkezniük, amelyeket 1917 tavaszáig az Amerikai Egyesült Államok budapesti külképviselete állított ki. A hazautazók csoportjában részt vevők részletes listáját a belügyminiszter hirdette ki. Általában kizárták azon személyeket, akik ellen büntető eljárás folyt, továbbá a kémgyanús vagy katonakorú személyeket is. Az olaszok esetében a katonakort meghaladó idős férfiakat is, ha tiszti rendfokozattal bírtak. ${ }^{196}$ Az útiköltséget előteremteni nem tudó személyek utazása díjtalan volt. Azok, akiknek jogszabály adta lehetősége volt hazautazni, azok dönthettek úgy is, hogy maradnak, amennyiben kellő vagyonnal rendelkeztek és már huzamosabb ideje Magyarországon éltek, továbbá kifogás alá nem estek. ${ }^{197}$ A hadiállapot Kína és az Osztrák-Magyar Monarchia közötti beálltát, 1917. VIII. 14-ét követően - 
az 1917. IX. 19-én kelt magyar belügyminiszteri rendelet - lehetővé tette, hogy a kínai állam-polgárok „nemre való tekintet nélkül az ország területét szintén elhagyhatják és Svájcba távozhatnak”, a meghatározott feltételek teljesítése mellett. ${ }^{198}$

\section{A magyarországi határforgalom ,helyreállása”, 1918-1920}

A I. világháborút lezáró padovai fegyverszünet aláírását, 1918. XI. 3-át követően az újabb és újabb, kijelölt fegyverszüneti vonalak határozták meg a magyar haderő által ellenőrzött határokat. Ezt azonban a nagyjából szétesett magyar hadsereg alig tudta ellenőrzése alatt tartani, azt elsősorban a megszálló államok katonái tették a túloldalon. E határokon átkelőket elsősorban katonai-rendészeti szempontból ellenőrizték, az okmányokat gyakorta a katonai parancsnokságok láttamozták. Ez alól csak az osztrákmagyar határ volt kivétel, ahol az utasforgalom ellenőrzése még továbbra is a történelmi határon, magyar rendvédelmi szervezetek által történt.

Az 1918. őszétől fokozatosan változó fegyverszüneti vonalak a magyar kormányt nehéz helyzet elé állították. A délnyugati vidékeken már 1918. november közepén a Drávát jelölték ki a megszállási határ vonalaként. Ezáltal a Horvát-Szlavónországba illetve Fiumébe történő utazás egyszersmind a délszláv haderők által megszállt területekre történő utazássá vált a gyakorlatban. Ezen állapot kezdeti hónapjaiban a magyar kormány nem léptetett életbe a korábbiakhoz képest korlátozó rendszabályokat, sőt, 1918. november első napjától az említett terület egésze elvesztette hadmüveleti területi besorolását. ${ }^{199}$ Ezáltal az oda utazáshoz nem volt szükség a korábbi igazoló okmányokra és engedélyekre. Azonban 1919 márciusának legelejére nyilvánvalóvá vált, hogy az oda történő utazás csak akkor ellenőrizhető, ha útlevél-kötelezettséget léptetnek életbe. Az útlevél helyett azonban egyelöre még lehetőség volt a meghatározottak szerint kiállított igazoló jeggyel is Horvát-Szlavónországba illetve Fiumébe utazni. ${ }^{200}$ Még 1918 november közepén felvonultak, majd a Kárpátok szorosain keresztül nyomultak a román haderő alakulatai is, ezzel a magyar államhatár ottani ellenőrzése kikerült a magyar közigazgatás irányítása alól. December elejére a román haderö Erdély jelentős részét ellenőrzése alá vonta. $^{201}$

A pénz és értékek kivitelének újabb szabályozása 1918. november közepén lépett hatályba, ennek megfelelöen külön engedély nélkül havonta egyszeri alkalommal csak 1000 korona összérték volt külföldre - illetve Magyarország meghatározott részeibe - vihető, ennek megfelelően a külföldre irányuló forgalom ellenőrzésének erre is kiterjedőnek kellett lennie. ${ }^{202}$ Már 1919 januárjától a huzamos időt távol tölteni szándékozók útlevelének kiállítását megelőzően, az igénylőnek vagyoni óvadékot kellett letétbe helyeznie. ${ }^{203}$ 1919. II. 11-től a határt átlépő magyar állampolgárok útleveleiben, az azt ellenőrző hatósági személyeknek ellenőrizniük kellett, hogy tartalmazzák-e a belügyminiszter azon záradékát, amely a pénzügyminiszternek a külföldre utazáshoz hozzájárulását rögzíti. ${ }^{204}$ Ezen felül az ellenőrzés kiterjedt arra is, hogy a kiutazó személy poggyásza - az általános utazási kellékeken illetve 2 000 koronáig terjedő készpénzen kívül - értéket nem tartalmaz-e, mivel azok kivitele - külön engedély hiányában - ekkor már tilalom alá estek (e rendelkezés megszegőit súlyos, akár a teljes ingó és ingatlan vagyon elkobzásával is büntethették). ${ }^{205}$ Március közepén már bevezetésre került a külföldre utazás elöre történő bejelentésének kötelezettsége is. Ezeken felül szigorították az útlevél kiadásának feltételeit is. A magyarországi tanácsköztársaság idején az utazási szabályok, és ezáltal ezek ellenőrzése tovább szigorodtak. ${ }^{206}$

A magyarországi tanácsköztársaság megalakulását követően komoly harcok bontakoztak ki a román hadsereg - majd hamarosan a cseh-szlovák haderő - által ellenőrzött fegyverszüneti vonalak mentén, amelyek végül 1919 augusztusának elején, a tanácskormány bukásával szüntek meg. A román csapatok 1919. VIII. 4-én bevonultak Budapestre, majd hamarosan a dunántúli vármegyék egy részébe is. ${ }^{207}$ A magyar belügyminiszter - a román katonai jelenlét hatása miatt - 1919. VIII. 8-án elrendelte, hogy minden kiállított útlevelet az utazás során érintett államok vízumainak beszerzésén kívül a Budapesten állomásozó román katonai hatóságnál is láttamoztatni kell. A tanácskormány idején kiadott valamennyi útlevél érvényét vesztette ekkor, a hazautazóktól a határforgalom ellenőrző hatóságok azokat bevonta és jelentés kíséretében a belügyminiszternek terjesztette fel. ${ }^{208} \mathrm{~A}$ budapesti román parancsnokság a magyar föváros pályaudvarain valamennyi utazásra jogosító okmányt - így az útleveleket és az igazoló jegyeket is - ellenőrizte, és engedélye estén láttamozta is, függetlenül, hogy az utazás külföldre vagy magyar vármegyék között történt. A román megszállás Budapesten 1919 november közepén ért véget, a megszálló hadsereg a Duna-Tisza-közéről a Tiszán túlra november végén vonult vissza. ${ }^{209}$

A magyar külképviseleti hálózat igen lassan épült ki, ezért a magyar közigazgatás által alkotott szabályoknak megfelelő útlevél-láttamozások, azaz a vízumok megkövetelése is fokozatos volt a kü- 
lönböző viszonylatú útlevél-ellenőrző állomásokon. A magyar (nép)köztársaság 1918 novemberétől müködtetett követségi rangú diplomáciai kirendeltséget Bécsben. Azonban újak a tanácskormány idején sem létesültek, különösen, hogy annak elismertsége igen szük volt. A magyar kormány belügyminisztere 1920 április elején rendelte el, hogy a délszláv állam felöl érkezö külföldiektől a nándorfehérvári magyar külképviselet útlevélhivatalának vízumát már követeljék meg a belépőktől. ${ }^{210} \mathrm{Az} 1920$. V. 20-án a belügyminiszter már úgy rendelkezett, hogy valamennyi határon illetve fegyverszüneti vonalon már csak az illetékes magyar külképviselet láttamozásával rendelkező külföldit lehet beléptetni. Továbbá elrendelte a korábbinál lényegesen részletesebb kimutatás vezetését, amely a határt átlépő minden személyről rögzíteni követelte meg: a nevét, az állampolgárságát, az állandó lakhelyét, az utazásának célját, az átlépés pontos idejét, az úti okmány megnevezését, kiállító hatóságát, keltét és számát, továbbá a külföldiek esetében a láttamozó magyar hatóság megnevezését is. ${ }^{211}$ Mint látható csak ennek a nyomtatványnak a kitöltése is jelentős időt vett igénybe az útlevelet kezelő hatósági személy részéről. Mindemellett a „megbízhatatlan” magyar állampolgárokról, illetve gyanús külföldiekről jelentést kellett tenni az úti cél szerint illetékes rendörhatóságnak, és esetleg a belügyminiszternek is. Ugyanígy jelentést kellett küldeni a kivándorlási biztosi hivatalnak a nagyobb létszámú, Amerikából visszatelepültek csoportjainak beléptetésével egyidőben. A magyar állampolgárnak az útlevelét, akinek kilépését - az okmány „szabálytalan” mivolta, vagy a kiviteli tilalom megszegése miatt - az átlépö-állomáson megtagadták, be kellett vonni és a kiállító hatóságnak az ok ismertetésével meg kellett küldeni. ${ }^{212}$

Határnak egyedül a magyar-osztrák szakasz volt tekinthető 1920 nyaráig, amely az Ausztriával 1919 szeptemberében kötött, Saint-Germain-en-Laye-i békeszerződés ellenére változatlan volt. A többi, állami igazgatást elválasztó vonal demarkációs vonal volt. A magyar hatóságok ellenőrzésének helyét általában még a semleges „be- és kilépő-állomásnak” nevezték meg, amely kifejezés kerülte a „határ” szót. 1920 májusáig, az osztrák szakaszt nem számítva - ahol az ellenőrzési helyek még a „békeidők"-ben felállításra kerültek -, még nem mindenhol volt létrehozva szükséges útlevél-ellenőrző szervezet. ${ }^{213}$ Az majd csak az év nyarán épült ki a kívánalmaknak megfelelő mértékben. A magyar hatóságok, a teljes magyar államhatáron át közlekedők valóságos és tényleges ellenőrzését csak a kíméletlen trianoni békediktátum aláírását, 1920. VI. 4-ét követően valósíthatták meg. Az új határátkelöhelyek első, tételes ismertetésére csak 1923-ban került sor, belügyminiszteri rendeletbe foglalva, azonban az ellenőrzés már 1920-ban megkezdődött az ott felsorolt települések határában. ${ }^{214}$

A magyar állampolgároknak, a román hadsereg által megszállt magyar vármegyékbe történő utazásához 1920 tavaszán a bécsi román képviselet vízumára volt szükség. Ezért a román állampolgárok részére - a román elöírásra válaszul, a viszonosság elvén - lényegében áthidalhatatlan akadályt emelt a magyar kormány. Románia területén akkor még nem volt magyar képviselet, ezért a rendeletnek megfelelően a bécsi magyar követségnél kellett a román útlevelüket láttamozni, még akkor is, ha Romániából utaztak a meg nem szállt Magyarország területére. Mindezek ellenére, érthető módon a vízumkényszer általánosan nem volt érvényben azon magyarokra, akik megszállt területen éltek, még akkor sem, ha úti okmányukat idegen állam állította ki, függetlenül a megszálló hatalomtól. ${ }^{215} 1920$ tavaszára a Magyarország jelentős részeit megszállás alatt tartó államok bevezették, hogy az általuk uralt területekre utazóknak már csak útlevélbe adják ki a beutazási engedélyüket. Ennek hatására a magyar belügyminiszter akkor engedte az ilyen településre utazni szándékozók részére az arcképes igazolójegy vagy más okmány kiállítását, ha azt a megszálló állam oda elfogadta. ${ }^{216}$ (A trianoni békediktátum aláírását követő november közepén lépett életbe az a miniszterelnöki rendelet, ami felállította a belügyminisztérium és az Országos Menekültügyi Hivatal munkatársaiból álló - az újonnan kijelölt államhatáron kívül maradt, de Magyarországra betelepülni szándékozó magyar lakosság ellenőrzésére - a Beköltözőket Ellenőrző Kirendeltségeket. ${ }^{217}$ Ezzel megkezdődött az elüldözöttek és a továbbra is Magyarország területén élni szándékozók befogadásának területileg központosított ügyintézése.) 
Jegyzetek:

1 1903/VI.tc. ; PARÁDI: A határszéli csendörség 1891-1904. ; Idem: A dualista Magyarország pénzügyi szerveinek határörizete 1867-1914. ; Idem: Pénzügyőrség és vámhivatalok a határörizetben. ; Idem: Csendörség a határörizetben. ; Idem: A határszéli csendőrség állambiztonsági feladatai. ; Idem: Rendőrség a határörizetben.

${ }^{2}$ PARÁDI: A pénzügyőrség szerepe a dualizmuskori Magyarország határőrizetében. 46-48.p. ; Idem: A magyar állam határőrizete a kiegyezéstől a II. vh-ig. ; Idem: A magyar határőrizet és az európai biztonság a XIX-XX. században 18671914. 123-138.p. ; Idem: A történelmi Magyarország határőrizeti tapasztalatai. ; Idem: Integrál rendvédelem a polgári magyar államban 1867-1945. ; Idem: Nemzeti határőrizetünk polgári szakasza. ; Idem: A dualista Magyarország határőrizete a migráció tükrében. ; Idem: Az Osztrák-Magyar Monarchia Magyar Királyságának határszéli csendőrsége.

3 PARÁDI: A dualista Magyarország határőrizeti rendszerének kialakulása. ; Idem: A polgári magyar állam első határőrizeti szakszerve a Magyar Királyi Határrendőrség 1906-1914. Idem: A Magyar Királyi Csendőrség határőrizeti feladatai 1891-1914. ; Idem: A Magyar Királyi Pénzügyminisztérium határörizeti feladatai az Osztrák-Magyar Monarchia magyarországi vámhatárain 1867-1914. ; Idem: A Magyar Királyi Pénzügyminisztérium határőrizeti feladatai az Osztrák-Magyar Monarchia magyarországi vámhatárain 1867-1914. Idem: A Magyar Királyi Határrendőrség, a magyar határőrizet szakmai vezető testülete.

4 PARÁDI: A polgári Magyarország határörizeti szervezetének kialakulása, tevékenységének jellemzői, a két világháború közötti magyar határőrizet változásai. ; Idem: A magyar határőrizet 1867-1945. ; Idem: A magyar állam határőrizeti struktúrájának fejlődése a századfordulótól a II. világháborúig. ; Idem: Határőrizet és kishatárforgalom a dualizmus alatt és a két világháború között. ; Idem: A dualizmuskori magyar rendvédelem és határőrizet. A Magyar Királyi Határrendőrség. ; Idem: A Magyar Királyi Határrendőrség. ; Idem: A magyar határőrizet tere a kiegyezéstől a második világháborúig. Idem: A Magyar Királyság határrendőrsége.

5 7 227/1912. (XII. 6.) ME.r. ； 60 121/1912. (XII. 10.) fk.int. ；192000/1912. (XII. 8.) BM.kr. ; 203 706/1913. (XII. 2.) BM.kr. ; 5 327/1914. (VII. 20.) ME.r. ; 11 101/1914. (I. 19.) BM.kr. ; 27 573/1914. (II. 11.) BM.kr.

6 GÁSPÁR - PARÁDI ; PARÁDI: Áttérés a háborús határőrizetre a II. világháború előtt.

${ }^{7}$ MEZEY ; 1912/LXIII.tc.

838 000/1913. (VI. 20.) BM.kr. Melléklet 15. §

9 Az Osztrák-Magyar Monarchia idején sosem használták a „külső” vagy a „,belső” határ megfogalmazását, ezért van tettem e tanulmányban idézőjelbe. „Belső” alatt említem azon határszakaszokat, amelyek az Osztrák Császárság és a Magyar Királyság, illetve Bosznia-Hercegovina közötti határok voltak. „Külső” alatt értendő a társországok egymással nem közös határai, ezt a vizsgált időszakban ,,vámhatár”-nak nevezték, mivel az Osztrák-Magyar Császárság, a Magyar Királyság és Bosznia-Hercegovina vámközösséget alkotott.

GALÁNTAI: 125-128.p. + 135-137.p.

10 SOM: 55-57. p.

1171 500/1904. (VII. 26.) BM.r. ; BENCSIK: A határforgalom főbb statisztikai jellemzői Magyarországon 1901-1915. ; PARÁDI: Rendörség a határörizetben. op.cit. IX.sz. melléklet. 254-257.p.

12 RADEN: 177.p.

13 Loc.cit.

14 Loc.cit. : 171.p.

15 Útvonala az alábbi volt 1913. második felében: PárizsBasel-Zürich-Innsbruck-Bécs-Budapest-Keleti pályaudvarZimony [magyar útlevél-ellenőrzés]-Belgrád [szerb útlevél-ellenőrzés]-Niš-Pirot [szerb útlevél-ellenőrzés]-Caribrod [bolgár útlevél-ellenőrzés]-Szófia-Plovdiv-Kada Koi [bolgár útlevél-ellenőrzés]-Edirne [török útlevél-ellenőrzés]-KonstantinápolySirkeci pályaudvar oda, s vissza (e vonatnak Budapest-Keleti pályaudvarnál csatlakozása volt a Berlinből érkező gyorsvonattal, illetve a szerbiai Niš-ben Thesszalonikibe).

Loc.cit.

${ }^{16}$ LÁNCZOS

1791 000/1905. (XII. 29.) BM.kr.

18 Az első polgári személyek Németországban repülhettek léghajóval. A német Deutsche Luftschiffahrts AG 1910. VI. 19vel kezdődően, a háború kitöréséig Zeppelin léghajóival összesen 33.722 utast szállított (harmaduk fizetőutas volt), részben séta-, részben Németországon belüli alkalmi távolsági repülések során. Az eredetileg tervezett, sőt beharangozott, nagy német városok közötti, menetrend szerinti légi közlekedést végül nem sikerült megvalósítani.

MONDEY: 228.p.

${ }^{19}$ A floridai St. Petersburg és Tampa között (belföldi forgalomban; közel 40 km-es útvonalon a Tampa-öböl két partját kötötte össze) 1914 első napjától a március végi kényszerü leállásig összesen 1.024 utast szállított az amerikai St. PetersburgTampa Airboat Line légitársaság.

Loc. cit.: 228.p.

207 227/1912. (XII. 6.) ME.r. op.cit. ； 7 252/1912. (XII. 6.) ME.r. ； 192 000/1912. (XII. 8.) BM.kr.

2160 121/1912.fk.int.

22203 706/1913. (XII. 2.) BM.kr.

23 PARÁDI: A Magyar Királyi Csendőrség határőrizeti szolgálata.

24 1903/VIII.tc. 2. §

25 Loc.cit. $7 . \S$

$2691000 / 1905$. (XII. 29.) BM.kr. op.cit.

2748 999/1912. (IV. 13.) BM.kr.

2858 320/1912. (IV. 13.) BM.kr.

2991 000/1905. (XII. 29.) BM.kr. op.cit. 15. § ; 38 000/1913. (VI. 20.) BM.kr. 13. § ; 3 389/1915. BM.kr.

30 PARÁDI: A Magyar Királyság határrendőrsége. op.cit. ; Idem: Rendörség a határörizetben. op.cit.

31 Idem: A csendőrség teendői az Osztrák-Magyar Monarchia Magyar Királysága külső határainak őrzésében. 
3291 000/1905. (XII. 29.) BM.kr. op.cit.

33 loc. cit.

34 loc. cit.

35 loc. cit.

${ }^{36}$ loc. cit.

${ }^{37}$ SOM: op.cit. 74.p.

${ }^{38}$ loc.cit. 284.p.

3991 000/1905. (XII. 29.) BM.kr. op.cit.

${ }^{40}$ Ebben az időben a haj- és szemszínre vonatkozó adatok is mérvadóak voltak. A hajszínt növényi fözetekkel lehetett ugyan módosítani, de a szem színének megváltoztatására ekkor még nem volt lehetőség.

4191 000/1905. (XII. 29.) BM.kr. op.cit.

${ }^{42}$ Loc.cit. $15 . \S$

43 Loc.cit. 3-12. \&

4438 000/1913. (VI. 20.) BM.kr.

4591 000/1905. (XII. 29.) BM.kr. op.cit.

46 loc. cit.

47 loc. cit.

48 A Föld országai közül 1910 nyarán még csak Ausztria, Belgium, Bulgária, az Egyesült Királyság, Franciaország, Monaco, Németország, Olaszország, Oroszország és Spanyolország állított ki nemzetközi úti igazolványt gépjármủvek számára. 73 000/1910. (V. 30.) BM.r.

49 loc. cit.

5091 000/1905. (XII. 29.) BM.kr. op.cit.

51 loc. cit.

52 loc. cit.

53 loc. cit.

54 loc. cit.

55133 285/1899. (I. 12.) BM.kr.

${ }^{56}$ A kivándorlásról szóló magyar jogszabály szigorú feltételeket szabott a kivándorlók részére, illetve meghatározta, hogy kik nem lehetnek kivándorlók, valamint rögzítette, hogy minden kivándorlónak abba az államba szóló útlevéllel kell ellátva lennie, a melybe kivándorolni szándékozik. E személyektől már Magyarország ausztriai illetve horvátországi határánál, vagy az ahhoz legközelebb eső nagyobb település állomásán kérték az úti okmányokat. A legtöbb kivándorló az Észak-amerikai Egyesült Államokba (Amerikai Egyesült Államok) illetve Romániába távozott, előbbi állam nem, míg utóbbi megkövetelte az úti okmány meglétét határai átlépésekor. Természetesen sok kivándorló úgy igyekezett távozni, hogy kijátszotta és megtévesztette a hatóságokat, s kivándorlásukat eltitkolva, útlevél nélkül hagyták el Magyarországot (döntően Észak-Amerika felé).

1903/IV.tc. ; BENCSIK: A magyar úti okmányok története 1867-1945. 25-26.p. + 31.p.

575 380/1910. (X. 1.) ME.r. ; 5 951/1912. (XI. 25.) ME.r.

58 336/1914. (I. 15.) ME.r. ; 11 101/1914. BM.kr.

5927 573/1914. (II. 11.) BM.kr.

${ }^{60}$ PogÁNY

${ }^{61}$ HAHNER

${ }^{62}$ Margitay-Becht: 186.p.

${ }^{63}$ A déli vármegyék tilalmi zónának nyilvánított légterébe tartozó területbe esett a Duna, a Száva és a Tisza-torkolat, valamint Temesvár, Versec, Nagybecskerek, vasútvonalak és vasúti csomópontok, továbbá a dunai vasúti híd és a Mirkovci területét.

5 327/1914. (VII. 20.) ME.r.

${ }^{64}$ Loc.cit.

${ }^{65}$ Osztrák-Magyar Vöröskönyv.

${ }^{66}$ Loc.cit. 87-88.p.

${ }^{67}$ A Világháború képes krónikája: 21-22.p.

${ }^{68}$ V. ö. 60. sz. jegyzet: 88. p.

${ }^{69}$ Osztrák-Magyar Vöröskönyv. op.cit.

70 Pollmann ; A szerb háború.

${ }^{71}$ Margitay-BECHT: op.cit. 186.p.

${ }^{72}$ E rendelet keletje 1914. július 27., de az 1914. július 26-án kiadott miniszterelnöki, szám nélküli, „Az 1912 : LXIII. t.c.-ben nyert felhatalmazás alapján a magyar királyi minisztérium és egyes miniszterek a következő cimű és mellékletképen a „Budapesti Közlöny” 170. számához csatolt, folyó évi julius hó 27-iki kelettel ellátott rendeleteket adják ki és azokat a mai hatállyal életbe léptetik:" címü rendelet (Magyarországi Rendeletek Tára, XLVII. évf. [1914] 1410-1413. p.) már július 26án életbe léptette, számos más rendelettel együtt.

5 111/1914. (VII. 27.) BM.r.

${ }^{73}$ E rendelet keletje 1914. VII. 27., de az 1914. VII. 26-án kiadott miniszterelnöki, szám nélküli rendelet már 1914. VII. 26-án életbe léptette, számos más rendelettel együtt.

5 474/1914. (VII. 27.) ME.r.

${ }^{74}$ E rendelet keletje 1914. VII. 27., de az 1914. VII. 26-án kiadott miniszterelnöki, szám nélküli rendelet már 1914. VII. 26-án életbe léptette, számos más rendelettel együtt.

5 471/1914. (VII. 27.) ME.r. 
${ }^{75}$ E rendelet keletje 1914. VII. 27., de az 1914. VII. 26-án kiadott miniszterelnöki, szám nélküli rendelet már 1914. VII. 26-án életbe léptette, számos más rendelettel együtt.

5 473/1914. (VII. 27.) ME.r.

$765735 / 1914$. (VIII. 1.) ME.r.

77 E rendelet keletje 1914. VII. 27., de az 1914. VII. 26-án kiadott miniszterelnöki, szám nélküli rendelet már 1914. VII. 26-án életbe léptette, számos más rendelettel együtt.

5 472/1914. (VII. 27.) ME.r.

${ }^{78}$ E rendelet keletje 1914. VII. 27., de az 1914. VII. 26-án kiadott miniszterelnöki, szám nélküli rendelet már 1914. VII. 26-án életbe léptette, számos más rendelettel együtt.

5 478/1914. (VII. 27.) ME.r.

${ }^{79}$ MARGitAy-Becht: op.cit.

${ }^{80}$ A Világháború képes krónikája. op.cit. 116. p.

81 Osztrák-Magyar Vöröskönyv. op.cit.

${ }^{82}$ Loc.cit.

${ }^{83}$ Loc.cit. 188. p.

${ }^{84}$ Gróf Errembault DE DUDZEELE a bécsi belga nagykövet.

A Világháború képes krónikája. op.cit. 143-144.p.

85 202 924/1914. (1915. I. 22.) BM.kr.

867 454/1915. (I. 7.) BM.kr.

875 526/1914. (VII. 27.) ME.r.

885 738/1914. (VIII. 1.) ME.r.

895 526/1914. (VII. 27.) ME.r. op.cit. ; 551/1915. (II. 9.) ME.r.

90 928/1916. (III. 21.) ME.r. 4. §

91 SOM: op.cit. 74.p.

924 031/1915. (XI. 8.) ME.r. ; LI-LA-RE. 1915/0218.

932 987/1915. (VIII. 14.) ME.r.

9440 500/1915. (XII. 13.) BM.kr.

95 285/1915. (I. 16.) ME.r. ; 36 250/1915. (IX. 26.) BM.r.

9629 491/1915. (VIII. 18.) BM.kr.

97 285/1915. (I. 16.) ME.r. op.cit. ; 36 250/1915. (IX. 26.) BM.r. op.cit.

98 Ide érendő 1915 végétől például egy svájci állampolgár, aki hazájából vasúton a Monarchia két államán, majd Románián keresztül utazott Oroszországba vagy Szerbiába, illetve visszafele. Ez ugyanígy előfordulhatott akár egy dán vagy holland alattvalóval is, aki érintve Németországot, a Monarchia két államát és Romániát Szerbiába vagy Oroszországba kívánt eljutni, illetve onnan haza. Azonban más útvonalak is lehetségesek voltak, de valószínüleg az útvonal választásánál legtöbbször a közlekedési nehézségeket, a háborúval járó kockázatokat (például a tengerhajózás esetében) és az anyagi ráfordítást együttesen mérlegelték. Természetesen minden utazónak, állampolgárságtól függetlenül az általa érintett országok beutazási engedélyeit - és szükség szerint további külön hozzájárulásokat - elöre, vagy esetleg utazása során be kellett szereznie.

${ }^{99}$ A kitiltott személyek aktualizált névjegyzékét a folyóirat e számaiban jelentették meg.

A Székesfövárosi M. Kir. Államrendörség Hivatalos Lapja. XII-XVI.évf. (1914-1918)

100 SUSLIK: 33-34.p.

101 E katonák közül a legénységi állományúak - 1917. augusztusi rendelet értelmében - 1916. októberétől készültségi pótdíjban is részesültek.

7 035/1916. (VI. 22.) HM.kr. ; 263 224/1917. (VIII. 9.) HM.r.

${ }^{102}$ A jelentkezés feltétele volt a magyar állampolgárságon, a „fedetlen elöéleten”, a magyar nyelv ismerete (szóban és írásban), az „egészséges testalkat” mellett még 1918 nyarán is, a hat év katonai vagy csendőri szolgálat, a 40 év alatti életkor és a ,rendezett anyagi viszonyok" is. Elönyt jelentett a magasabb végzettség vagy műveltség, illetve a más magyarországi nyelv ismerete is. Külön előnyben részesültek, akik a háború folyamán kitüntetést kaptak vagy akik „,a harctéren vagy a katonai szolgálatban rokkantakká” váltak. A jelentkezőknek 3 évi szolgálatot kellett vállalnia, továbbá azt, hogy bármelyik határrendőr kapitányságra helyezhetik. A felhívásra a tényleges szolgálatban állók is pályázhattak, a pályázati kérvényt sajátkezüleg kellett megírni és azt - a születési anyakönyvi kivonattal, a minősítési táblázat másolatával, az iskolai és az orvosi bizonyítványokkal valamint további okmányokkal együtt - a Magyar Királyi Belügyminisztériumhoz kellett továbbítani.

A próbaidő hat hónap volt, a véglegesítéshez külön vizsgát kellett tenni. Az évi fizetést 1000 koronában (havi 83,33 korona) állapították meg, amelyen felül lakhatási pótlék, vagy lakás, továbbá háborús, helyi vagy családi pótlék, valamint évi 175,62 korona ruhapénz, egyenruházati átalány járt.

371 183/1917. (X. 13.) HM.ért. ； 21 225/1918. (VIII. 27.) HM.ért.

103 1916/XXXVII.tc. ; 37 000/1917. (III. 23.) BM.kr.

1043 389/1915. (VIII. 18.) BM.kr. op.cit. ; $116835 / 1915$. (XI. 7) BM.r. ； 18 262/1916. (II. 20.) BM.r.

${ }^{105}$ A románok erősítik a magyar határt.

106 1903/VIII.tc. op.cit.

10714 139/1915. (V. 8.) BM.kr.

10824 550/1915. (VII. 20.) BM.kr.

1093 389/1915. (VIII. 18.) BM.kr. op.cit.

110 Andrees Allgemeiner Handatlas: 73-74.p.

111 285/1915. (I. 16.) ME.r. op.cit. ; 36 250/1915. (IX. 26.) BM.r. op.cit.

112 loc. cit. 
113 Magyarországon ezt, és az eljárás rendjét a kereskedelmi miniszter már 1914 szeptember közepén kiadott rendelete részletezte. Ennek hatására a központi hatalmak szövetséges államai egymás közötti postaforgalmát is cenzúrázták. Az egymással hadban álló felek közötti közvetlen postaforgalom legkésőbb a hadba lépéssel egyidőben megszünt. Azonban a rendőri őrizet alatt állók (internáltak) illetve a hadifoglyok miatt részlegesen müködött a szolgáltatás - tüzetes ellenőrzés mellett amely minden esetben egy semleges állam postaszolgálatán keresztül bonyolódott le.

1919/1914. (IX. 10.) KM.r. ； 2 248/1914. (XII. 2.) KM.r. ； 8 591/1915. (III. 12.) BM.kr. ； 31 557/1915. (X. 17.) BM.r.

1142 449/1915. (I. 22.) ME.r.

11574 379/1915. (XI. 3.) KM.r.

11686 541/1915. (XII. 24.) KM.r.

11793 676/1917. (XII. 15.) KM.közl.

118 285/1915. (I. 16.) ME.r. op.cit. ; 36 250/1915. (IX. 26.) BM.r. op.cit.

1194 031/1915. (XI. 8.) ME.r. op.cit.

${ }^{120}$ Loc.cit. ; LI-LA-RE. 1915/0218.op.cit.

121 A császári és királyi Szerbiai Katonai Főkormányzóság Útlevélhivatala által kiállított útlevelet a Főkormányzóság nándorfehérvári nyomdájában gyártották. A 152×106 mm méretü, szürke, puha karton borító előoldalán az 1915. évi osztrákmagyar közös kiscímer és az okmány megnevezése volt látható egyszerü díszítés felett. A német egynyelvü, 16 oldalas úti okmány első belső előzékre a fénykép hitelesítő hatósági záradéka került kialakításra, a vízjel és alnyomat nélküli fehér lapok oldalainak elrendezése megegyezett a korszak osztrák útleveleivel - ezáltal eltért a magyaroktól -, kiegészülve az ,állampolgárság”, a „munka- és foglalkozás városa” és a „beszélt nyelv” rovatokkal, a kiállító hatóság megnevezése és a keltezés az 5. oldalon volt olvasható. Az első oldalon a címer alatt az „Im Namen Sr. Exellenz des k. u. k. Militär-General-Gouverneurs.” (azaz „Őexcellenciája cs. és. kir. Katonai Főkormányzó nevében.”) felirat volt olvasható. (A leírás az 1917. évi, „K. u. k. Gouvernement-Druckerei in Belgrad. - Bez. 2637 ex 1917.” nyomdai jelzetü altípusról készült)

${ }^{122} \mathrm{Az}$ utlevelek és igazoló jegyek láttamozása Szerbia egész területére.

123 GRANDE ; The „Balkanzug”

124 GRANDE: op.cit.

12518 174/1917. (IX. 1.) HM.r.

126 PARÁDI: A Magyar Királyi Csendőrség határőrizeti szolgálata. op.cit.

1274 308/1916. (XII. 23.) ME.r.

$1283000 / 1917$. (I. 30.) BM.kr.

1294 244/1917. (II. 4.) BM.r.

${ }^{130}$ Som: op.cit. 37.p.

131233 637/1917. (IX. 12.) HM.r.

132105 038/1917. (IX. 9.) BM.r.

133 Loc.cit.

134 Loc.cit.

135153 966/1914. (VIII. 23.) BM.kr.

136160 436/1914. (IX. 15.) BM.kr.

1379 175/1914. (XI. 25.) BM.r.

1385 738/1914. (VIII. 1.) ME.r. op.cit.

139 Loc.cit

14076 142/1904. (VII. 28.) BM.kr.

14127 186/1915. (III. 10.) BM.kr.

142103 523/1915. (IX. 3.) BM.kr.

143477 372/1917. HM.r.

144 RADEN: op.cit.

1459 941/1915 (III. 23.) BM.kr. ; 94 830/1915 (VII. 22.) BM.r.

146 Granica település az osztrák-orosz határt képező Biała Przemsza-folyó északi, orosz-lengyelországi partján feküdt. A két ország között húzódó vasúti hídon közlekedő szerelvények is biztosították a térségben határt átlépők forgalmát. A község mai neve Maczki.

94 830/1915 (VII. 22.) BM.r. op.cit.

147 Szczakowa az osztrák-orosz határt képező Biała Przemsza-folyó déli, orosz-lengyelországi partján feküdt. A két ország között húzódó vasúti hídon közlekedő szerelvények is biztosították a térségben határt átlépők forgalmát, északi határában már az 1910-es évek elején is számottevő rendező pályaudvar üzemelt. E község napjainkban Jawarzno város északi településrésze.

33 942/1915. (X. 17.) BM.r.

14829 491/1915. (VIII. 18.) BM.kr. op.cit.

14940 500/1915. (XII. 13.) BM.kr. op.cit. ; 130 599/1915. (XI. 7.) BM.r.

150 Som: op.cit.

${ }^{151}$ Loc.cit.

152 Az útlevelek és igazoló jegyek láttamozása Szerbia egész területére. op.cit.

${ }^{153}$ Míg 1914 tavaszán egy osztrák-magyar korona 0,207 amerikai dollárt ért, addig 1915 januárjában 0,174-et, júliusban 0,151-et, 1916 első heteiben 0,127-et, júliusban 0,127, 1917 januárjában már csak 0,113-at; egy korona 1914 elején 0,85 német márkát, 1915-ben 0,71 illetve 1916-ban 0,69 márkát ért, míg 1917-ben már csak 0,65-öt.

154134 980/1916. (IX. 2.) BM.kr.

15527 805/1917. (III. 21.) BM.kr.

1564 272/1916. (III. 28.) HM.kr.

${ }^{157}$ Az útlevelek és igazoló jegyek láttamozása Szerbia egész területére. op.cit.

158 BENCSIK: A magyar úti okmányok története 1867-1945. op.cit. 144-145.p.

1591 544/1917. (II. 3.) BM.kr. 
1605 028/1917. (II. 16.) BM.kr.

${ }^{161}$ Loc.cit.

162 A tájékoztatás tévesen Kereskedelmi Múzeumot említ a Kereskedelmi Minisztérium helyett.

Románia megszállott területeire szóló utazásokhoz szükséges utazási engedélyek.

1639 125/1917. BM.res.közl.

${ }^{164}$ A tervezett tartózkodás minden hete után 3 márka díj megfizetése volt kötelezö.

734/1916. BM.res.közl.

${ }^{165}$ Az útlevelek és igazoló jegyek láttamozása Szerbia egész területére. op.cit.

166 Loc.cit.

1674 433/1917. (IX. 19.) ME.r.

1682 200/1918. (III. 13.) ME.r.

169 Loc.cit.

17022 649/1918. (IX. 17.) HM.r.

1712 958/1917. (III. 18.) HM.hat.

172 Ennek értelmében a közös határaikon ellenőrzés nem állt fenn, s Liechtenstein Svájccal közös határszakaszán a feldkirchi osztrák császári pénzügyigazgatóság hatóságai személyei végezték a vámellenőrzést, s ezen vámhivatalok osztrák császáriak és liechtensteini hercegiek egyaránt voltak.

1876/XLVIII.tc.

173 LI-LA-RE op.cit. 1914/2132 ad 2131

174 Így 1915 január második felétől az osztrák-liechtensteini államhatárt az alábbi útvonalakon lehetett átlépni:

- Amerlügen (Feldkirchtől délkeletre);

- Tisis közút (a liechtensteini Schaanwald felé);

- Tisis vasútmegálló;

- Altenstadt;

- Feldkirch vasútállomás.

Loc.cit. 1915/0218

175 Loc.cit. $1915 / 0218$

17632 000/1915. (IX. 10.) BM.kr.

177 GROB

178 LI-LA-RE op.cit. 1915/3700 ad 0218

179 A magyar szent korona országainak 1910. évi népszámlálása: 2.p.

Az 1900. évi népszámlálás adatai szerint Magyarországon - Horvát-Szlavónországok nélkül - 7126 német, 6389 olasz, 1479 román, 1265 bolgár, 1230 szerb, 961 svájci, 956 orosz, 776 brit, 775 francia, 530 török és mindösszesen 113 belga, 92 holland, 63 görög, 42 montenegrói, 41 svéd, 24 dán, 14 spanyol, 8 norvég, 7 luxemburgi, 3 brazil, 3 japán és csak 1 portugál állampolgár élt; ázsiaiak további 15 fö, afrikai 15 fö, amerikai államokból további 952 fő volt itt.

A magyar Szent Korona országainak 1900. évi népszámlálása. 42-49.p.

180 A magyar szent korona országainak 1910. évi népszámlálása. 14.p.

${ }^{181}$ Kitiltott személyek jegyzékei.

182 1903/V.tc. 10. §.

${ }^{183}$ Az Amerikai Egyesült Államoknak 1914-ben az Osztrák-Magyar Monarchiában csak Bécs és Budapest, valamint Trieszt, Prága, Reichenberg (Liberec) és Karlsbad (Karlovy Vary) városaiban voltak konzuli képviseletei.

285/1915. (I. 16.) ME.r. ; 36 250/1915. (IX. 26.) BM.r. op.cit.

184157 653/1914. (IX. 18.) BM.kr.

185 285/1915. (I. 16.) ME.r. op.cit.

1869 496/1914. fk.eln.közl.

1878 626/1914. (XI. 16) BM.kr.

1882 438/1915. (I. 22.) BM.kr. op.cit.

189 Már az 1910-es évek elején is több kínai állampolgár tartózkodott az Osztrák-Magyar Monachia területén, s Kína 1917 nyarának végéig semleges maradt. Japán és az Osztrák-Magyar Monarchia 1914. VIII. 24-én hadiállapotba került egymással, s így a japán állampolgárokat az Osztrák-Magyar Monarchia területén rendöri felügyelet alá kellett vonni, mint ellenséges hadviselő fél állampolgárait. A Kínai Köztársaság bécsi nagykövete - elkerülendő a felesleges kellemetlenségeket és a lakosság ellenségeskedéseit - még augusztus 14-én úgy döntött, hogy a kínai állampolgárok részére „vörös-aranysárga-kék-fehér középen fekete gombbal ellátott kokárdát oszt ki”.

3043/1914.fk. eln.res.közl. Magyarországon tartózkodó orosz és szerb alattvalók védelme.

A Székesfövárosi M. Kir. Államrendörség Hivatalos Lapja, XII. évf. (1914) 36.sz. 321.p.

19010 962/1915. (IV. 9.) BM-IM.kr.

191 285/1915. (I. 16.) ME.r. op.cit. ; 36 250/1915. (IX. 26.) BM.r. op.cit.

19229 491/1915. (VIII. 18.) BM.r.

1934 586/1915. ME.r.

194 10 767/1915. (II. 10.) BM.r.

$1951355 / 1916$. BM.r.

196 18 711/1915. (VI. 24.) BM.kr. ; 9 051/1916. (III. 26.) BM.kr.

${ }^{197}$ Andrees Allgemeiner Handatlas. op.cit.

19813 705/1917.(X. 7.) Bp.RFK.táj.

1995 028/1917. (II. 16.) BM.kr. op.cit.

20032 129/1919. BM.kr.

201 SUBA

2025 211/1918. (XI. 11.) ME.r. 


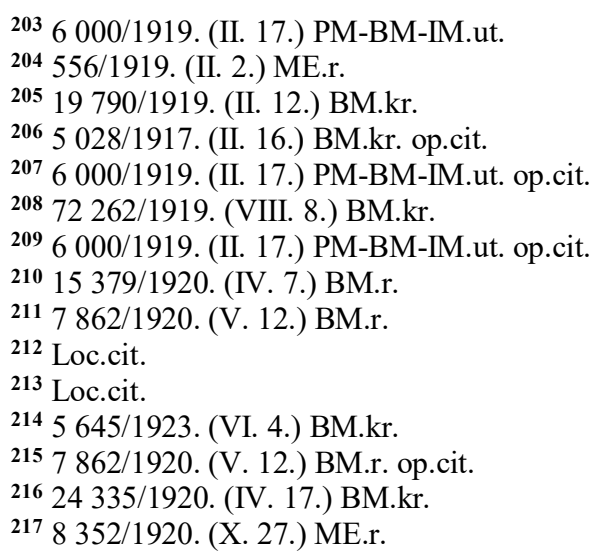

\section{Jegyzetekben alkalmazott röviditések:}

\section{MONOGRÁFIÁK, KISMONOGRÁFIÁK ÉS HASONLÓ JELLEGÜ KÖTETEK}

A Világháború képes krónikája. (67.;68.; 80.;84.;)

\section{GALÁNTAI}

(9.;)

BENCSIK: A magyar úti okmányok története 1867-1945.

(56.;158.,)

MARGITAY-BECHT (62.; 71.; 79.;)

MONDEY

$(18 . ; 19 ;)$

\section{PARÁDI: A határszéli} csendörség 1891-1904. (1.;)

PARÁDI: A dualista Magyarország pénzügyi szerveinek határörizete 1867-1914.

(1.;)

PARÁDI: Pénzügyőrség és vámhivatalok a határörizetben.

(1.;)

PARÁDI: Csendőrség a határörizetben.

(1.;)

PARÁDI: Rendőrség a ha- tárörizetben.

(1.;11.;30.;)

RADEN

(12.;13;14;15;144.;)

SoM

(10.;37.;38.;91.;130; $150 . ; 151 . ;)$
SÜLE Antal (szerk.): A Világháború képes krónikája. I. kötet. Budapest, 1914, Révai Testvérek Irodalmi Intézet Rt. 416 p.

GalánTAi József: A Habsburg-monarchia alkonya. Osztrák-magyar dualizmus 18671918. Budapest, 1985, Kossuth. 387 p. HU-ISBN 9630925893.

- BENCSIK Péter: A magyar úti okmányok története 1867-1945. Budapest, 2003, Tipico Design Kft. 179 p. HU ISBN 9637623337.

- Margitay-Becht András, id.: A Leitha monitor ... és a többiek. Budapest, 2007, Hadtörténeti Intézet és Múzeum - Petit Real Könyvkiadó. 372 p. HU-ISBN 9789637097263.

- Mondey, David (szerk.): The International Encyclopedia of Aviaton. [A repülés nemzetközi enciklopédiája.] London, 1988, Octopus Books Limited - The Hamlyn Publishing Group. 480 p. UK ISBN 0600560805.

— PARÁDI József: A határszéli csendőrség 1891-1904. Budapest, 1984, Határörség. 95 p. HU-ISBN -

PARÁDI József: A dualista Magyarország pénzügyi szerveinek határörizete 1867-1914. Budapest, 1987, Határőrség. 123 p. HU-ISBN —

PARÁDI József: Pénzügyőrség és vámhivatalok a határőrizetben. Budapest, 2003, Tipico Design. 219 p. HU-ISBN 963762330 2. /Rendvédelem a határokon a XIX-XX. században, 1./ HU-ISSN -

PARÁDI József: Csendőrség a határörizetben. Budapest, 2003, Tipico Design. 2186 p. HU-ISBN 963762331 0. /Rendvédelem a határokon a XIX-XX. században, 2./ HU-ISSN

PARÁDI József: Rendőrség a határôrizetben. Budapest, 2003, Tipico Design. 266 p. HUISBN 963762332 9. /Rendvédelem a határokon a XIX-XX. században, 3./ HU-ISSN —

Raden, Alexander Sixtus von: Az Osztrák-Magyar Monarchia, Történelmi dokumentumok. Budapest - Salzburg, 1989, Széchenyi Kiadó - Druckhaus Nonntal Bücherdienst. 307 p. HU ISBN 9630272075.

SoM Krisztián: A magyar úti okmányok, 1848-2012. Budapest, 2014, Nemzetbiztonsági Szakszolgálat - Szemere Bertalan Magyar Rendvédelem-történeti Tudományos Társaság. 313 p. HU ISBN 9789638982834. 
SUSLIK

(100.;

)

\section{TANULMÁNYOK}

BENCSIK: A határforgalom fóbb statisztikai jellemzői Magyarországon 1901-1915.

(11.; )

GÁSPÁR - PARÁDI

(6.; )

LÁNCZOS

(16.;)

MeZEY

(7.;)

PARÁDI: A dualista Magyarország határőrizeti rendszerének kialakulása. (3.;)

PARÁDI: A polgári magyar állam első határörizeti szakszerve a Magyar Királyi Határrendőrség 1906-1914.

(3.;)

PARÁDI: A Magyar Királyi Csendőrség határőrizeti feladatai 1891-1914.

(3.;)

PARÁdI: A Magyar Királyi Pénzügyminisztérium határőrizeti feladatai az Osztrák-Magyar Monarchia magyarországi vámhatárain 1867-1914.

(3.;)

PARÁDI: A Magyar Királyi Határrendőrség, a magyar határörizet szakmai vezetö testülete.

(3.;)

PARÁDI: Áttérés a háborús határörizetre az első világháború előtt.

$(6 . ;)$
SusLIK Ádám: A honvédség szerveződése a mai Kárpátalja területén 1868-1914 között. Ungvár, 2012, Kárpátaljai Magyar Müvelődési Intézet. 39 p. /KMMI-Füzetek XVII.,/ ISSN -

BENCSIK Péter: A határforgalom fóbb statisztikai jellemzői Magyarországon 19011915. Rendvédelem-történeti Füzetek (Acta Historiae Praesidii Ordinis), XVII.évf. (2009) 20.sz. 13-37.p. A tanulmány korábbi változata 2006 szeptember 29-én Budapesten hangzott el a Szemere Bertalan Magyar Rendvédelem-történeti Tudományos Társaság által szervezett rendvédelem-történeti tudományos konferenciasorozatnak „A XIX-XX. századi magyar forradalmak hatása a nemzeti rendvédelmi rendszerünkre" címü XX. konferenciáján. A publikált tanulmány az előadás javított, bővített és átdolgozott változata.

GÁSPÁR László - PARÁDI József: A magyar határőrizeti szervek feladatai, a katonai határőrizetre történő áttérés időszakában 1912-1914. ZMKA Akadémiai Közlemények, XXII.évf. (1987) 134.sz. 131-151.p. HU-ISSN 1218-5507.

LÁNCzos Péter: Száz éves a CIWL 2347 pályaszámú étkezőkocsi (1912-2012). Vasútgépészet, XXV.évf. (2012) 2.sz. 4-10.p. HU ISSN 0230-0605.

MeZEy Barna: A kivételes hatalom. Rendvédelem-történeti Füzetek (Acta Historiae Praesidii Ordinis), IV.évf. (1994) 5.sz. 4-6.p. HU-ISSN 1216-6774. A tanulmány korábbi változata 1993. szeptember 21.-én Budapesten hangzott el a Szemere Bertalan Magyar Rendvédelem-történeti Tudományos Társaság által szervezett rendvédelem-történeti tudományos konferenciasorozatnak a „Háború, forradalom, trianon” című V. konferenciáján. A publikált tanulmány az előadás javított, bővített és átdolgozott változata.

PARÁDI József: A dualista Magyarország határörizeti rendszerének kialakulása. Belügyi Szemle, XXX.évf. (1982) 10.sz. 44-51.p. HU-ISSN 0133-6738.

PARÁDI József: A polgári magyar állam első határőrizeti szakszerve a Magyar Királyi Határrendőrség 1906-1914. Hadtörténelmi Közlemények, CI.évf. (1986) 3.sz. 541-570. p. HU-ISSN 0017-6540.

PARÁDI József: A Magyar Királyi Csendőrség határőrizeti feladatai 1891-1914. Hadtörténelmi Közlemények, CIII.évf. (1988) 1.sz. 56-92.p. HU-ISSN 0017-6540.

PARÁDI József: A Magyar Királyi Pénzügyminisztérium határőrizeti feladatai az Osztrák-Magyar Monarchia magyarországi vámhatárain 1867-1914. Hadtörténelmi Közlemények, CIV.évf. (1989) 2.sz. 177-196.p. HU-ISSN 0017-6540.

PARÁDI József: A Magyar Királyi Határrendőrség, a magyar határőrizet szakmai vezető testülete. Rendvédelem-történeti Füzetek (Acta Historiae Praesidii Ordinis), III.évf. (1993) 4.sz. 21-50.p. HU-ISSN 1216-6774. A tanulmány korábbi változata 1992 szeptember 29-én Budapesten hangzott el a Szemere Bertalan Magyar Rendvédelem-történeti Tudományos Társaság által szervezett rendvédelem-történeti tudományos konferenciasorozatnak „A dualista Magyarország rendvédelme” címü IV. konferenciáján. A publikált tanulmány az előadás javított, bővített és átdolgozott változata.

PARÁDI József: Áttérés a háborús határőrizetre az első világháború előtt. Rendvédelem-történeti Füzetek (Acta Historiae Praesidii Ordinis), IV.évf. (1994) 5.sz. 13-17.p. HU-ISSN 1216-6774. A tanulmány korábbi változata 1993. szeptember 21én Budapesten hangzott el a Szemere Bertalan Magyar Rendvédelem-történeti Tudományos Társaság által szervezett rendvédelem-történeti tudományos konferenciasorozatnak a „Háború, forradalom, trianon” címü V. konferenciáján. A publikált tanulmány az elöadás javított, bővített és átdolgozott változata. 
PARÁDI: A polgári Ma- gyarország határőrizeti szervezetének kialakulása, tevékenységének jellemzői, a két világháború közötti magyar határőrizet változásai.

(4.;)

PARÁDI: A magyar határőrizet 1867-1945.

(4.;)

PARÁDI: A magyar állam határőrizeti struktúrájának fejlődése a századfordulótól a második világháborúig.

(4.; )

PARÁDI: Határőrizet és kishatárforgalom a dualizmus alatt és a két világháború között.

(4.; )

PARÁDI: A pénzügyőrség szerepe a dualizmuskori Magyarország határörizetében.

(2.,)

PARÁDI: A magyar állam határörizete a kiegyezéstől a II. vh-ig.

(2.;)

PARÁDI: A történelmi Magyarország határörizeti tapasztalatai. (2.;)

PARÁDI: A magyar határ- örizet és az európai biztonság a XIX-XX. században 1867-1914.

(2.;)

PARÁDI: A határszéli csendőrség állambiztonsági feladatai.

(1.;)
PARÁDI József: A polgári Magyarország határőrizeti szervezetének kialakulása, tevékenységének jellemzői, a két világháború közötti magyar határőrizet változásai. Határőrségi Tudományos Közlemények, IV.évf. (1994) 1.sz. 4-23.p. HU-ISSN —

PARÁDI József: A magyar határőrizet 1867-1945. Határőrségi Tanulmányok, (1997) 1. sz. különszáma. 11-35. p.

PARÁDI József: A magyar állam határőrizeti struktúrájának fejlődése a századfordulótól a második világháborúig. Határőrségi Tanulmányok, VII.évf. (1999) 5.sz. különszám 27-48.p. és 14 melléklet. A tanulmány korábbi változata 1999. október 6án Budapesten hangzott el a Szemere Bertalan Magyar Rendvédelem-történeti Tudományos Társaság által szervezett rendvédelem-történeti tudományos konferenciasorozatnak „A közigazgatás, a véderő és a rendvédelem kapcsolatának változásai a polgári magyar állam időszakában" címü XII. konferenciáján. A publikált tanulmány az előadás javított, bővített és átdolgozott változata.

PARÁDI József: Határőrizet és kishatárforgalom a dualizmus alatt és a két világháború között. Rendvédelem-történeti Füzetek (Acta Historiae Preasidii Ordi-nis), X.évf. (2000) 11.sz. 42-53.p. HU-ISSN 1216-6774. A tanulmány korábbi válto-zata 1999. április 20-án Budapesten hangzott el a Szemere Bertalan Magyar Rendvédelem-történeti Tudományos Társaság által szervezett rendvédelem-történeti tudományos konferenciasorozatnak a „Szabad mozgás a Kárpát-medencében” címü XI. konferenciáján. A publikált tanulmány az előadás javított, bővített és átdolgozott változata.

PARÁDI József: A pénzügyőrség szerepe a dualizmuskori Magyarország határörizetében. In. BERTA Gyula (szerk.): Somogy megyei rendvédelem-történeti szimpózion 2001-2002. Kaposvár, 2002, Szemere Bertalan Magyar Rendvédelem-történeti Tudományos Társaság. 46-48.p. A tanulmány korábbi változata 2001. szeptemberében Kaposváron hangzott el a Szemere Bertalan Magyar Rendvédelem-történeti Tudományos Társaság „Dél-Pannon Rendvédelem-történeti napok” címü szimpozion sorozatának 2001. évi rendezvényén. A publikált tanulmány az előadás javított, bővített és átdolgozott változata. HU-ISBN -

PARÁDI József: A magyar állam határőrizete a kiegyezéstől a II. vh-ig. 74-109.p. In BODA József (szerk.): A magyar polgári rendvédelem a XIX-XX. században. A magyar büntetés-végrehajtás, csendörség, határörség, koronaőrség, rendörség, vámés pénzügyörség. Budapest, 2004, Belügyminisztérium Nemzetközi Oktatási Központ - Szemere Bertalan Magyar Rendvédelem-történeti Alapítvány. 2015 p. A tanulmány korábbi változata 2003. nyarán Budapesten hangzott el a Szemere Berta-lan Magyar Rendvédelem-történeti Alapítvány által szervezett magyar rendvédelemtörténeti témájú nyári szabadegyetemen. A publikált tanulmány az előadás javított, bővített és átdolgozott változata. HU-ISBN -

PARÁDI József: A történelmi Magyarország határőrizeti tapasztalatai. 357-388.p. In Mezey Barna (szerk.): Eckhart Ferenc emlékkönyv. Budapest, 2004, Gondolat Kiadó. HU-ISBN 963950086 0. /Jogtörténeti értekezések, 28./ HU-ISSN 0134-0026.

PARÁDI József: A magyar határôrizet és az európai biztonság a XIX-XX. században 1867-1914. 123-138.p. In HAUTZINGER Zoltán (szerk.): Tanulmányok a „Magyar határellenörzés - európai biztonság” címü tudományos konferenciáról. Pécs, 2004, Magyar Hadtudományi Társaság Határörizeti Szakosztályának Pécsi Szakcsoport. 294 p. HU-ISBN — /Pécsi Határőr Tudományos Közlemények, III./ HU-ISSN 15891674.

PARÁDI József: A határszéli csendőrség állambiztonsági feladatai. Rendvédelemtörténeti Füzetek (Acta Historiae Praesidii Ordinis), XI.évf. (2005) 14.sz. 91-41.p. HU-ISSN 1216-6774. A tanulmány korábbi változata 2002 februárjában, Budapesten hangzott el, a Szemere Bertalan Magyar Rendvédelem-történeti Tudományos Társaság Csendőrség-történeti Szakosztálya által szervezett tudományos szimpozionsorozatnak a „Csendörség Magyarországon” címü II. konferenciáján. A publikált tanulmány az előadás javított, bővített és át-dolgozott változata. 
PARÁDI : A dualizmuskori magyar rendvédelem és határörizet. A Magyar Királyi Határrendőrség. (4.; )

PARÁDI: Integrált rendvé- delem a polgári magyar államban 1867-1945. (2.;)

PARÁDI: A magyar határ- örizet tere a kiegyezéstől a második világháborúig. (4.;)

PARÁDI: A Magyar Ki- rályi Határrendőrség. (4.;)

PARÁdi: A Magyar Királyi Csendőrség határörizeti szolgálata. (23.;126.;)

PARÁDI József: A Magyar Királyság határrendőrsége. (4.;30.;)

PARÁDI: A csendőrség teendői az Osztrák-Magyar Monarchia Magyar Királysága külső határainak örzésében.

(31.;)

PARÁDI: A dualista Magyarország határőrizete a migráció tükrében. (2.;)

PARÁDI: Az OsztrákMagyar Monarchia Magyar Királyságának határszéli csendőrsége.

(2.;)
PARÁDI József: A dualizmuskori magyar rendvédelem és határőrizet. A Magyar Királyi Határrendőrség. Határrendészeti Tanulmányok, III.évf. (2006) 1.sz. 5-46.p. HU-ISSN 1786-2345. A tanulmány korábbi változata 2006. január 17-én Budapesten hangzott el a Szemere Bertalan Magyar Rendvédelem-történeti Tudományos Társaság és a Határörség Országos Parancsnoksága közös szervezésében megvalósított konferencián. „Az ezeréves magyar rendvédelem” című XIV. konferenciáján. A publikált tanulmány az előadás javított, bővített és átdolgozott változata.

PARÁDI József: Integrált rendvédelem a polgári magyar államban 1867-1945. 7179.p. In Hautzinger Zoltán (szerk.): Tanulmányok a „Határőrség és rendörség az integrált rendvédelemben" címü tudományos konferenciáról. Pécs, 2007, Magyar Hadtudományi Társaság Határőrizeti Szakosztályának Pécsi Szakcsoportja. 255 p. HUISBN — /Pécsi határör tudományos közlemények, VII./ HU-ISSN 1589-1645.

PARÁDI József: A magyar határőrizet tere a kiegyezéstől a második világháborúig. Rendvédelem-történeti Füzetek (Acta Historiae Praesidii Ordinis), XII.évf. (2007) 15.sz. 125-138.p. HU-ISSN 1216-6774. A tanulmány korábbi változata 2005. augusztus 27-én a szlovéniai Lendván hangzott el a Hajnal István kör által szervezett tudományos konferencián. A publikált tanulmány az előadás javított, bővített és átdolgozott változata.

PARÁDI József: A Magyar Királyi Határrendőrség. Rendvédelem-történeti Füzetek (Acta Historiae Praesidii Ordinis), XII. évf. (2007) 15.sz. 139-159.p. HU-ISSN 1216-6774. A tanulmány korábbi változata 2004. áprilisában Budapesten hangzott el a Szemere Bertalan Magyar Rendvédelem-történeti Tudományos Társaság Rendőrség-történeti Szakosztálya által szervezett Szemere Beszélgetések szimpózionsorozat rendezvényén a Rendőrség Tudományos Tanácsának közreműködésével. A publikált tanulmány az előadás javított, bővített és átdolgozott változata.

PARÁDI József: A Magyar Királyi Csendőrség határőrizeti szolgálata. Rendvédelem-történeti Füzetek (Acta Historiae Praesidii Ordinis), XIX.évf. (2010) 22. sz. 77-91.p. A tanulmány korábbi változata 2008. október 10-én Budapesten hangzott el, a Sze-mere Bertalan Magyar Rendvédelem-történeti Tudományos Társaság által szervezett rendvédelem-történeti tudományos konferenciasorozatnak ,Másfél évszázad rend-szerváltozásainak hatásai a nemzeti rendvédelmünkre” címü XXII. konferenciáján. A publikált tanulmány az előadás javított, bővített és átdolgozott változata.

PARÁDI József: A Magyar Királyság határrendőrsége. Rendvédelem-történeti Füzetek (Acta Historiae Praesidii Ordinis), XVIII.évf. (2010) 21.sz. 101-116.p. HUISSN 1216-6774. A tanulmány korábbi változata 2007 október 5-én Budapesten hangzott el a Szemere Bertalan Magyar Rendvédelem-történeti Tudományos Társaság által szervezett rendvédelem-történeti tudományos konferenciasorozatnak „, $A$ magyar rendvédelem fejlödése a XIX-XX. században " címü XXI. konferenciáján. A publikált tanulmány az előadás javított, bőví-tett és átdolgozott változata.

PARÁDI József: A csendőrség teendői az Osztrák-Magyar Monarchia Magyar Királysága külső határainak őrzésében. Rendvédelem-történeti Füzetek (Acta Histo-riae Preasidii Ordinis), XXI.évf. (2011) 24.sz. 100-118.p. HU-ISSN 1216-6774. A tanulmány korábbi vál-tozata 2009. december 3-án, Budapesten hangzott el, a Szemere Bertalan Magyar Rendvédelem-történeti Tudományos Társaság által szervezett rendvédelem-történeti tudományos konferenciasorozatnak „Csendörség AusztriaMagyarországon, illetve Ausztriában és Magyarországon 1849-2005” címü XXIV. konferenciáján. A publikált tanulmány az előadás javított, bővített és átdolgozott változata.

PARÁDI József: A dualista Magyarország határőrizete a migráció tükrében. Rendvédelem-történeti Füzetek (Acta Historiae Praesidii Ordinis), XXII.évf. (2012) 26.sz. 66-80.p. A tanulmány korábbi változata 2011.november 11-én, Budapesten hangzott el, a Szemere Bertalan Magyar Rendvédelem-történeti Tudományos Társaság által szervezett rendvédelem-történeti tudományos konferenciasorozatnak ,,Militarizmus és demilitarizmus a XIX-XX. századi magyar állam rendvédelmében” címü XXV. konferenciáján. A publikált tanulmány az előadás javított, bővített és átdolgozott változata.

PARÁDI József: Az Osztrák-Magyar Monarchia Magyar Királyságának határszéli csendőrsége. Rendvédelem-történeti Füzetek (Acta Historiae Praesidii Ordinis), XXII.évf. (2012) 26.sz. 81-104.p. HU-ISSN 1216-6774. A tanulmány korábbi változata 2011 november 11-én, Budapesten hangzott el, a Szemere Bertalan Magyar Rendvédelem-történeti Tudományos Társaság által szervezett rendvédelem-történeti tudományos konferencia-sorozatnak ,,Militarizmus és demilitarizmus a XIX-XX. századi magyar állam rendvédelmében” címü XXV. konferenciáján. A publikált tanulmány az előadás javított, bővített és átdolgozott változata. 
PARÁDI: Nemzeti határőrizetünk polgári szakasza.

(2.;)

POGÁNY

$(60 . ;)$

SUBA

(201.)
PARÁDI József: Nemzeti határőrizetünk polgári szakasza. Rendvédelem-történeti Füzetek (Acta Historiae Praesidii Ordinis), XXIII.évf. (2013) 27-28-29-30.sz. 141154.p. HU-ISSN 1216-6774.

PogÁnY Ágnes: Az Osztrák-Magyar Bank az I. világháború és a forradalmak idején, 1914-1919. In BÁCSKAI Tamás (szerk.): A Magyar Nemzeti Bank története. I. Az osztrák Nemzeti Banktól a Magyar Nemzeti Bankig, 1816-1924. Budapest, 1993, Közgazdasági és Jogi Kiadó. 343-412. p. HU ISBN 9632226615.

SuBA János: Magyarország területi integritásának helyreállítása 1919-1920. Rendvédelem-történeti Füzetek (Acta Historiae Praesidii Ordinis), XVI.évf. (2009) 19.sz. 105-113.p. A tanulmány korábbi változata 2005. október 07-én, Budapesten hangzott el a Szemere Bertalan Magyar Rendvédelem-történeti Tudományos Társaság által szervezett rendvédelem-történeti tudományos konferenciasorozatnak „,Másfél évtized nemzeti rendvédelem-történetünk kutatásának szolgálatában” címü XIX. konferenciáján. A publikált tanulmány az előadás javított, bővített és átdolgozott változata.

\section{STATISZTIKAI KÖZLEMÉNYEK}

\author{
A magyar Szent Korona \\ országainak 1900. évi \\ népszámlálása. \\ (179.;) \\ A magyar szent korona \\ országainak 1910. évi \\ népszámlálása. \\ (180.;) \\ ATLASZOK
}

Andrees Allgemeiner Handatlas. (110.;197.;)
Magyar Statisztikai Közlemények. A magyar Szent Korona országainak 1900. évi népszámlálása. III.rész. A népesség részletes leírása. Budapest, 1907, Magyar Királyi Központi Statisztikai Hivatal. 746 p.

A magyar szent korona országainak 1910. évi népszámlálása. I.rész. Budapest, 1912, Magyar Királyi Központi Statisztikai Hivatal. 880 p.

\section{DOKUMENTUM-GYÜJTEMÉNYEK}

Osztrák-Magyar Vöröskönyv.

(65.;66.;69.;81.;82.;

83.;)

\section{CIKKEK}

A románok erősítik a magyar határt.

(105.;)

A szerb háború.

(70.,)

GRANDE

(123.;124.;)

GROB

(177.;)

HAHNER

(61.;)

POLLMANN

(70.;)

The ,Balkanzug”

(123.; )
Osztrák-Magyar Vöröskönyv. Diplomáciai akták a háború elözményeinek történetéhez. Budapest, 1915, Atheneum Irodalmi Nyomda és Nyomdai Részvénytársulat. $144 \mathrm{p}$.

Andrees Allgemeiner Handatlas. [Andrees Általános Kézi Atlasz] 6. bővített kiadás. Bielefeld - Leipzig, 1914, Velhagen \& Klasing. 216 p.

\section{LEVÉL- IRAT- ÉS DOMUMENTUMTÁRI GYÜJTEMÉNYEK}

LI-LA-RE. (120.;173.;174.;175.; 178.;)

\section{JOGSZABÁLYOK}

1876/XLVIII.tc.

(172.;)

1903/IV.tc.

(56.; ) (szerkesztőségi közlemény) A románok erösítik a magyar határt. Szentesi Lap, XLIV.évf. (1915) 76.sz. 2.p.

A szerb háború. Szentesi Lap, XLIII. évf. (1914) 61. sz., 2-3. p. (szerkesztőségi összefoglaló)

GRANDE, Julian: New „Balkan Express”. [Az új Balkán Gyorsvonat.] The Press, LVI.évf. (1916) 15547.sz. 8.p.

GROB őrnagy, a (svájci) 76. Népfölkelő zászlóalj parancsnokának tájékoztatása. Liechtensteiner Volksblatt, (1914) 35.sz. 1914.08.29., 4.p.

HAHNER Péter: Franciaország 1914-ben. A Harmadik Köztársaság vállalja a háborút. Rubicon, XXIV évf. (2014) 4-5.sz. 38-49. p. HU-ISSN 0865-6347.

POLLMANN Ferenc: Dilettáns háborútervezés. Anekdotikus történetek a hadüzenet napjaiból. Rubicon, XXIV.évf. (2014) 4-5.sz. 82-86.p. HU-ISSN 0865-6347.

(Szerkesztőségi közlemény.) The „Balkanzug”. [A Balkánvonat.] Kalgoorlie Western Argus, XXI.évf. (1916) 1916.05.09-i sz. 32.p.

Liechtensteinische Landesarchiv Regierung [Liechtensteini Országos Levéltár Kormányzati Iratok]

1876/XLVIII. tc. a liechtensteini fejedelemséggel 1876. évi deczember 3-án kötött adó- és vámegyesülési szerződés beczikkelyezéséről.

1903/IV.tc. a kivándorlásról. 
1903/V.tc

(182.;)

1903/VI.tc.

(1.;)

1903/VIII.tc.

(24.;25.;106.; )

1912/LXIII.tc.

(7.;)

1916/XXXVII.tc.

(103.;)

133 285/1899. (I. 12.)

BM.kr.

(55.;)

71 500/1904. (VII. 26.) -

BM.r.

(11.; )

76 142/1904. (VII. 28.) -

BM.kr.

(140.;)

91 000/1905. (XII. 29.) -

BM.kr.

$(17 . ; 26 . ; 32 . ; 33 . ; 34$.;

35.;36.;39.;41.;42.;

43.;45.;46.;47.;50.;

51.;52.;53.;54.;)

$5380 / 1910$. (X. 1.)

ME.r.

(57.;)

73 000/1910. (V. 30. )

BM.kr.

(47.;48.;49.; )

5 951/1912. (XI. 25.)

ME.r.

(57., )

7 227/1912. (XII. 26.)

ME.r.

(5.;20;)

7 252/1912. (XII. 6.) -

ME.r.

(20.;)

48 999/1912. (IV. 13.) -

BM. kr.

(27.; )

58 320/1912. (IV. 13.) -

BM.kr.

(28.; )

192 000/1912. (XII. 8.) -

BM.kr.

(5.;20.;)

38 000/1913. (VI. 20.) -

BM.kr.

(8.;29.;41.;)

203 706/1913. (XII. 2.) -

BM. kr.

(5.;22.;)

336/1914. (I. 15.) ME.r. $(58 . ;)$
1903/V.tc. külföldieknek a magyar korona országai területén való lakhatásáról.

1903/VI.tc. az útlevélügyről.

1903/VIII.tc. a határrendőrségről.

1912/LXIII.tc. a háború esetére szóló kivételes intézkedésekről.

1916/XXXVII.tc. a fiumei m. kir. állami rendőrségröl.

133 285/1899. (I. 12.) BM.kr. az osztrák-magyar léghajós katonatiszteknek Németország területén leszállhatása tárgyában és viszont.

Magyarországi Rendeletek Tára, XXXI.évf. (1898) 29-30.p.

71 500/1904. (VII. 26.) BM.r. a határforgalom ellenőrzéséről, az útlevelek vizsgálatáról, az úti igazolványok kiállításáról és a forgalmi adatok gyüjtéséről.

Magyarországi Rendeletek Tára, XXXVII.évf. (1904) 716-729.p.

76 142/1904. (VII. 28.) BM.kr. az útlevelek láttamozása.

Belügyi Közlöny, XXXVII.évf. (1904) 38.sz. 427.p.

91 000/1905. (XII. 29.) BM.kr. a határrendőrségről szóló 1903. VIII. t. cikk életbeléptetése és végrehajtása. Utasítás a „határrendőrségröl” szóló 1903/VIII.tc. végrehajtása tárgyában.

Magyarországi Rendeletek Tára, XXXVIII. évf. (1905) 1455-1540. p.

5 380/1910. (X.1.) ME.r. az útlevélkötelezettségnek Szerbiával szemben való megszüntetéséröl.

Magyarországi Rendeletek Tára, XLIII.évf. (1910) I.füzet. 603.p.

73 000/1910. (V. 30.) BM.kr. a nemzetközi utiigazolvánnyal vagy e nélkül közlekedő gépjármüvekre vonatkozó eljárásról.

Magyarországi Rendeletek Tára, XLIII.évf. (1910) 367-375.p.

5 951/1912. (XI. 25.) ME.r. az útlevélkötelezettségnek Szerbiával szemben újból elrendelése.

Belügyi Közlöny, XLV.évf. (1912) 50.sz. 429.p.

7 227/1912. (XII. 6.) ME. r. az 1909:II. t.-c. 2. §-a b) pontjának első bekezdésében megjelölt védkötelesek férfiszemélyek kivándorlásának megtiltása.

Belügyi Közlöny, XLV. évf. (1912) 52. sz. 441. p.

7 252/1912. (XII. 6.) ME.r. a fegyveres erők kötelékébe tartozó egyének részére útlevelek kiadásának beszüntetése.

Belügyi Közlöny, XLV.évf. (1912) 52.sz. 441.p.

48 999/1912. (IV. 13.) BM.kr. határrendőri külszolgálatnak átvétele a m. kir. csendőrség által.

Belügyi Közlöny, XLV.évf. (1912) 18.sz. 141-145.p.

58 320/1912. (IV. 13.) BM.kr. a határrendőri külszolgálat ellátása a határrendörségi őrségek megszüntetésével.

Belügyi Közlöny, XLV.évf. (1912) 18.sz. 136-140.p.

192 000/1912. (XII. 8.) BM.kr. a ministeriumnak az 1909:II. t.-c. 2. §-ában megjelölt védkötelesek kivándorlásának betiltására és a fegyveres erők kötelékébe tartozó egyének részére az útlevelek kiadásának beszüntetésére vonatkozó rendeletei.

Belügyi Közlöny, XVII. évf. (1912) 52. sz. 442. p.

38 000/1913. (VI. 20.) BM.kr. a határrendőrsegről szóló 1903 : VIII. t.-c.-nek Fiume városa és kerülete területén való életbeléptetéséről és végrehajtására. Magyarországi Rendeletek Tára, XLVI.évf. (1913) 1032-1070.p.

203 706/1913. (XII. 2.) BM.kr. az 1909:II. t.-c. 2. §-a b) pontjában felsorolt férfi személyek kivándorlásának betiltására és a fegyveres erő kötelékébe tartozó egyének részére szóló útlevelek kiadásának beszüntetésére vonatkozó rendeletek hatályon kívül helyezése.

Belügyi Közlöny, XVIII. évf. (1913) 53. sz. 584-585. p.

336/1914. (I. 15.) ME.r. a határon kilépni készülő osztrák állampolgároktól és bosznia-hercegovinai tartományi illetőségűektől hadkötelezettségük szempontjából kívánt igazolásról.

Magyarországi Rendeletek Tára, XLVII.évf. (1914) I.füzet. 21-23.p. 


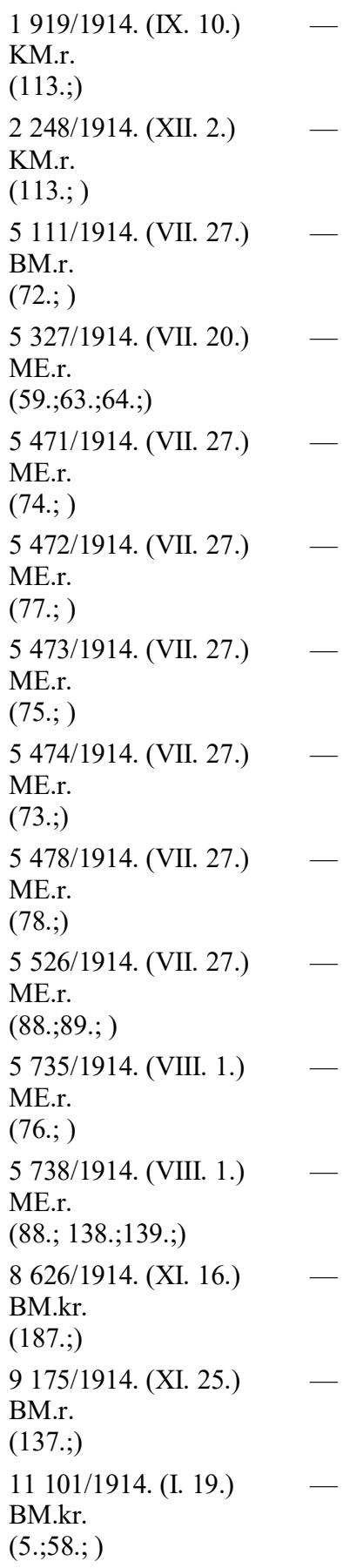

1 919/1914. (IX. 10.) KM.r. a külföldre szóló levelek nyitva feladásáról. Magyarországi Rendeletek Tára, XLVII. évf. (1914) 2485-2486.p.

2 248/1914. (XII. 2.) KM.r. internáltak levelezésének ellenséges államokkal való közvetítéséröl.

Magyarországi Rendeletek Tára, XLVII.évf. (1914) 2974-2977.p.

5 111/1914. (VII. 27.) BM.r. a határátlépés korlátozásáról. Magyarországi Rendeletek Tára, XLVII.évf. (1914) 1513-1514.p.

5 327/1914. (VII. 20.) ME.r. a légi közlekedés tilalmi zónája tárgyában. Belügyi Közlöny, XIX.évf. (1914) 37.sz. 495-496.p.

5 471/1914. (VII. 27.) ME.r. a fegyveres erő kötelékébe tartozó egyének részére útlevelek kiadásának beszüntetéséröl. Magyarországi Rendeletek Tára, XLVII.évf. (1914) 1414.p.

5 472/1914. (VII. 27.) ME.r. az útlevélkötelezettségnek Montenegróval szemben elrendeléséről.

Magyarországi Rendeletek Tára, XLVII.évf. (1914) 1415.p.

5 473/1914. (VII. 27.) ME.r. az útlevélkiállitás jogának a belügyminiszter, illetöleg a bán hatáskörébe utalásáról.

Magyarországi Rendeletek Tára, XLVII.évf. (1914) 1415.p.

5 474/1914. (VII. 27.) ME.r. a hadköteles férfi személyek kivándorlásának megtiltásáról. Magyarországi Rendeletek Tára, XLVII. évf. (1914) 1416.p.

5 478/1914. (VII. 27.) ME.r. a postai, távirdai és távbeszélö-forgalom ellenörzéséröl.

Magyarországi Rendeletek Tára, XLVII.évf. (1914) 1423-1426.p.

5 526/1914. (VII. 27.) ME.r. több cikk ki- és átvitelének tilalmáról. Magyarországi Rendeletek Tára, XLVII.évf. (1914) 1441-1444.p.

5 735/1914. (VIII. 1.) ME.r. a háború esetére szóló kivételes intézkedések tárgyában kiadott rendeletek hatályának kiterjesztéséröl.

Magyarországi Rendeletek Tára, XLVII.évf. (1914) 1448-1450.p.

5 738/1914. (VIII. 1.) ME.r. több cikk ki- és átvitelének tilalmáról.

Magyarországi Rendeletek Tára, XLVII.évf. (1914) 1450-1457.p.

8 626/1914. (XI. 16.) BM.kr. a monarchiával hadi állapotba jutott államok internálva nem lévő alattvalóinak összeírásáról.

Magyarországi Rendeletek Tára, XLVII.évf. (1914) 2754-2757.p.

9 175/1914. (XI. 25.) BM.r. a háború kitörésekor Belgiumból elmenekült magyar állampolgárok oda való visszatérése tárgyában.

A Székesfövárosi M. Kir. Allamrendörség Hivatalos Lapja. XII.évf. (1914) 49.sz. 471-472.p.

11 101/1914. (I. 19.) BM.kr. a határon kilépni készülő osztrák állampolgároktól és bosznia-hercegovinai tartományi illetőségüektől, hadkötelezettségük szempontjából, a m. kir. miniszterium 1914. évi 336. M.E.sz. rendelete értelmében kívánt igazolás körüli eljárásról.

Magyarországi Rendeletek Tára, XLVII.évf. (1914) I.füzet. 24-27.p.

27 573/1914. (II. 11.) BM.kr. a határon kilépni készülő magyar állampolgároknak az osztrák- és bosznia-hercegovinai hatóságok előtt, hadkötelezettségük szempontjából való igazolása tárgyában.

A Székesfövárosi M. Kir. Államrendörség Hivatalos Lapja, XII.évf. (1914) 9.sz. 61.p.

153 966/1914. (VIII. 23.) BM.kr. a hadüzenetek következtében az útlevelek kiállítása körül követendő eljárásról.

Magyarországi Rendeletek Tára, XLVII.évf. (1914) 1562.p.

157 653/1914. (IX. 18.) BM.kr. az Észak Amerikai Egyesült Államok állampolgárainak szabad közlekedése.

A Budapesti M. Kir. Állami Rendörség Hivatalos Lapja, XII.évf. (1914) 39.sz. 347.p.

160 436/1914. (IX. 15.) BM.kr. Olaszországban utlevél és utlevélláttamozási kényszer.

A Budapesti M. Kir. Állami Rendörség Hivatalos Lapja, XII.évf. (1914) 39.sz. 347.p. 
$202924 / 1914$.

(1915. I. 22.) BM.kr.

(85.; )

285/1915. (I. 16.) ME.r. (95.;97.;111.;112.;118.; 183.;185.;191.;)

551/1915. (II. 9.)

ME.r.

(89.;)

2 438/1915. (I. 22.)

BM.kr.

(114.;188.;)

2 987/1915. (VIII. 14.) -

ME.r.

(93., )

3 389/1915. (VIII. 18.) -

BM.kr.

(29.; 104.;)

4 031/1915. (XI. 8.)

ME.r.

(92.; 109.;119.;120.;)

4 586/1915. (XII. 27.) -

ME.r.

(93.;)

7 454/1915. (I. 7.)

BM.kr.

(86.;)

8 591/1915 (III. 12.) -

BM.kr.

(113.; )

9 941/1915 (III. 23.)

BM.kr.

(145.;)

10 767/1915. (II. 10.) -

BM. r.

(194.;)

10 962/1915. (IV. 9.) BM- -

IM.kr.

(190.;)

14 139/1915. (V. 8.) -

BM.kr.

(107.;)

$18711 / 1915$. (VI. 24.) -

BM.kr.

(196.;)

24 550/1915. (VII. 20.) -

BM.kr.

(108.; )

27 186/1915. (III. 10.) -

BM.kr.

(141.;)

29 491/1915. (VIII. 18.) -

BM.kr.

(96.;148.;192.;)

31 557/1915. (X. 17.) -

BM.r.

(113.; )

32 000/1915. (IX. 10.) -

BM.kr.

(176.;)
202 924/1914. (1915. I. 22.) BM.kr. az Északamerikai Egyesült-Államok állampolgárainak utlevelei.

Magyarországi Rendeletek Tára, XLVIII.évf. (1915) 158-159.p.

285/1915. (I. 16.) ME.r. az útlevélkötelezettség elrendeléséröl.

Magyarországi Rendeletek Tára, XLVIII. évf. (1915) 38-40.p.

551/1915. (II. 9.) ME.r. több cikk ki- és átvitelének tilalmáról. Magyarországi Rendeletek Tára, XLVIII.évf. (1915) 56-66.p.

2 438/1915. (I. 22.) BM.kr. a hazájukba visszatérni, illetőleg ittmaradni óhajtó francia és angol állampolgárok nyilatkozatainak bekívánása.

Belügyi Közlöny, XX.évf. (1915) 6.sz. 46-49.p.

2 987/1915. (VIII. 14.) ME.r. az idegenek és a náluk lévő tárgyak fokozott ellenőrzéséröl.

Magyarországi Rendeletek Tára, XLVIII.évf. (1915) 1189-1191.p.

3 389/1915. (VIII. 18.) BM.kr. a határátkelési pontok megállapítása.

Magyarországi Rendeletek Tára, XLVIII.évf. (1915) 1256-1258.p.

4 031/1915. (XI. 8.) ME. r. az útlevélkötelezettség elrendeléséről szóló 285/1915. M. E. szám alatt kiadott rendelet kiegészítése.

Magyarországi Rendeletek Tára, XLVIII.évf. (1915) 1725.p.

4 586/1915. (XII. 27.) ME.r. a liszt- és kenyérfogyasztásnak szabályozása.

Belügyi Közlöny, XX.évf. (1915) 60. sz. 1375-1377.p.

7 454/1915. (I. 7.) BM.kr. Németországban és Hollandiában elrendelt útlevél- és útlevél-láttamozási kényszerről.

Magyarországi Rendeletek Tára, XLVIII.évf. (1915) 153-154.p.

8 591/1915. (III. 12.) BM.kr. az ellenséges államok területén hadifogságban levő katonáink és ugyanott internált honfitársaink részére szánt postai küldemények feladási módozatairól.

Belügyi Közlöny, XX.évf. (1915) 14.sz. 244-248.p.

9 941/1915 (III. 23.) BM.kr. Orosz-Lengyelország okkupált területére való utazáshoz szükségelt utazási igazolvány.

Belügyi Közlöny, XX.évf. (1915) 14.sz. 248.p.

10 767/1915. (II. 10.) BM.r. az idegen diplomaták részére kiadott igazolási jegyek. A Székesfövárosi M. Kir. Államrendörség Hivatalos Lapja. XIII.évf. (1915) 8.sz. 107-109.p.

10 962/1915. (IV. 9.) BM-IM.kr. a rendőri felügyelet alá helyezésnek és az őrizet alá vételnek szabályozásáról.

Belügyi Közlöny, XX.évf. (1915) 20.sz. 379-385.p.

14 139/1915. (V. 8.) BM.kr. Magyarországon internált szerb és Szerbiában internált magyar állampolgárok egy részének hazabocsátásáról.

Magyarországi Rendeletek Tára, XLVIII.évf. (1915) 788-790.p.

18 711/1915. (VI. 24.) BM.kr. az olasz állampolgárok egy részének hazabocsátása. Belügyi Közlöny, XX. évf. (1915) 33.sz. 667-668.p.

24 550/1915. (VII. 20.) BM.kr. az orosz állampolgárok egy részének hazabocsátásáról.

Belügyi Közlöny, XX.évf. (1915) 37.sz. 766-767.p.

27 186/1915. (III. 10.) BM.kr. a Romániába szóló útlevelek konzuli láttamozásáról és a láttamozásért fizetendő konzuli illetékről.

Magyarországi Rendeletek Tára, XLVIII.évf. (1915) 213.p.

29 491/1915. (VIII. 18.) BM.kr. az idegenek és a náluk lévő tárgyak fokozott ellenőrzése tárgyában kiadott 2.987/1915. M. E. sz. rendelet végrehajtásáról.

Magyarországi Rendeletek Tára, XLVIII.évf. (1915) 1258-1259.p.

31 557/1915. (X. 17.) BM.r. A hadifoglyok csomagjainak Olaszországgal való kölcsönös forgalma.

Belügyi Közlöny, XX.évf. (1915) 49.sz. 1145.p.

32 000/1915. (IX. 10.) BM.kr. hadmüveleti területen a polgári személyforgalom korlátozásáról és az igazolási kötelezettség szabályozásáról.

Magyarországi Rendeletek Tára, XLVIII.évf. (1915) 1788-1811.p. 


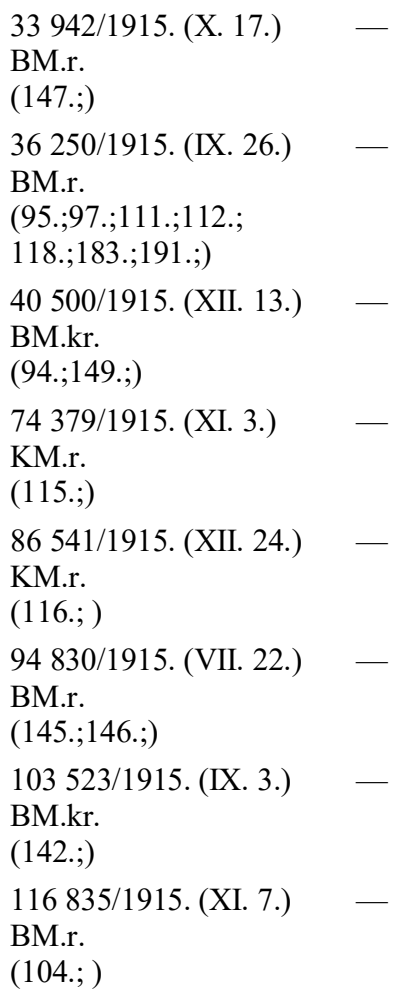

33 942/1915. (X. 17.) BM.r. Oroszlengyelország megszállott területeire kiállított útlevelek láttamozása.

Belügyi Közlöny, XX.évf. (1915) 49.sz. 1145.p.

36 250/1915. (IX. 26.) BM.r. határszéli utiigazolványok kiállitása.

Belügyi Közlöny, XX.évf. (1915) 46.sz. 1032-1033.p.

40 500/1915. (XII. 13.) BM.kr. a hadműveleti területen való utazás újabb szabályozása.

Belügyi Közlöny, XX.évf. (1915) 58.sz. 1337-1341.p.

74 379/1915. (XI. 3.) KM.r. látképes levelezőlapok forgalmának korlátozásáról. Magyarországi Rendeletek Tára, XLVIII.évf. (1915) 2025.p.

86 541/1915. (XII. 24.) KM.r. látképes levelezőlapok forgalmának további korlátozásáról.

Magyarországi Rendeletek Tára, XLVIII.évf. (1915) 2256.p.

94 830/1915. (VII. 22.) BM.r. Oroszlengyelország megszállott területeire kiállított útleveleknek Krakón és Granicán történő láttamozása.

Belügyi Közlöny, XX.évf. (1915) 41 sz. 915.p.

103 523/1915. (IX. 3.) BM. kr. a Bulgáriában elrendelt utlevélláttamozási kényszerről.

Magyarországi Rendeletek Tára, XLVIII.évf. (1915) 1786.p.

116 835/1915. (XI. 7.) BM.r. határszéli útiigazolványok kiállítása tárgyában. Belügyi Közlöny, XX.évf. (1915) 52.sz. 1202.p.

(A rendelet szövegéböl kiderül, hogy létezett e rendelet témakörében már egy másik „107 900/1915.BM.r.” amely azonban sem levéltári sem nyomtatott formában nem került elö.)

130 599/1915. (XI. 7.) BM.r. Orosz-Lengyelország megszállott területeire kiállított útlevelek láttamozása.

Belügyi Közlöny, XX.évf. (1915) 52.sz. 1202.p.

928/1916. (III. 21.) ME.r. több cikk kivitelének és átvitelének tilalmáról. Magyarországi Rendeletek Tára, XLIX.évf. (1916) 145-158.p.

1355/1916. (I. 27.) BM.r. az idegen diplomaták részére kiadott új igazolási jegyek. A Székesfövárosi M. Kir. Államrendörség Hivatalos Lapja, XIV.évf. (1916) 7.sz. 129-130.p.

4 272/1916. (III. 28.) HM.kr. Németországba szóló utazási okmányok. Rendeleti Közlöny a Magyar Királyi Honvédség számára, XLII.évf. (1916) 20.sz. 136.p.

4 308/1916. (XII. 23.) ME.r. a külföldi fizetési eszközökkel való kereskedésröl és forgalomról és a külfölddel való forgalom korlátozásáról. Magyarországi Rendeletek Tára, XLIX.évf. (1916) 1651-1656.p.

7 035/1916. (VI. 22.) HM.kr. a m.kir. határrendőrséghez vezényelt katonai személyek alárendeltsége.

Rendeleti Közlöny a Magyar Királyi Honvédség számára (szabályrendeletek), XLII.évf. (1916) 42.sz. 307-308.p.

9 051/1916. (III. 26.) BM.kr. az olasz állampolgárok egy részének hazabocsátásáról. Belügyi Közlöny, XXI.évf. (1916) 16.sz. 416.p.

18 262/1916. (II. 20.) BM.r. határszéli uti igazolványok kiállítása. Belügyi Közlöny, XXI.évf. (1916) 9.sz. 225.p.

134 980/1916. (IX. 2.) BM.kr. a Törökországba utazni szándékozók részére kiállítandó bizonyítványokról.

Belügyi Közlöny, XXI. évf. (1916) 999.p.

1 544/1917. (II. 3.) BM.kr. az ország területén tartózkodó romániai állampolgárok bizonyos csoportjának összeírásáról.

Magyarországi Rendeletek Tára, L.évf. (1917) 616-617.p.

3 000/1917. (I. 30.) BM.kr. a hadműveleti és megszállott területekre vonatkozó utazási szabályokról.

Magyarországi Rendeletek Tára, L.évf. (1917) 584-614.p. 


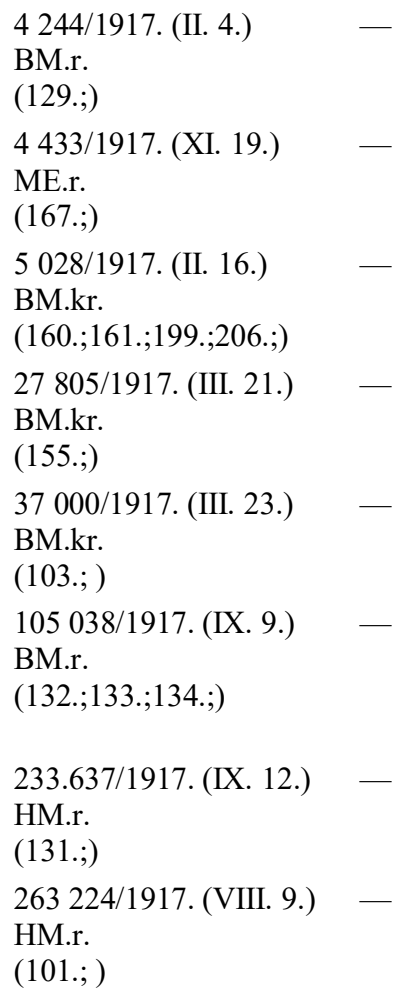

4 244/1917. (II. 4.) BM.r. német útlevelek pótívekkel való el-látásának tilalma. Belügyi Közlöny, XXII.évf. (1917) 6.sz. 203.p.

4 433/1917. (XI. 19.) ME.r. az útlevélkötelezettség elrendeléséről szóló 285/1915. M.E. szám alatt kiadott rendelet módosításáról.

Magyarországi Rendeletek Tára, L.évf. (1917) 2332-2333.p.

5 028/1917. (II. 16.) BM.kr. a 17-55 éves összes romániai alattvaló férfiszemélyek internálásáról.

Magyarországi Rendeletek Tára, L. évf. (1917) 622-623.p.

27 805/1917. (III. 21.) BM.kr. Törökországba utazók fényképeinek a török főkonzulnál leendö letétbe helyezése.

Belügyi Közlöny, XXII.évf. (1917) 16.sz. 412.p.

37 000/1917. (III. 23.) BM.kr. A Fiumei Magyar Királyi Állami Rendőrségről szóló 1916:XXXVII. törvénycikk végrehajtása és a hatáskörök körülírása. Belügyi Közlöny, XXII.évf. (1917) 16.sz. 406-411.p.

105 038/1917. (IX. 19.) BM.r. a Balkán-félszigetre vagy egyáltalán keletre utazó német állampolgárok hatályos ellenőrzése.

A Székesfövárosi Magyar Királyi Államrendörség Hivatalos Lapja. XV.évf. (1917) 47.sz. 1061.p.

233 637/1917. (IX. 12.) HM. r. szabadságolt legénység által elvitt czikkek.

Kisközlöny a „,Rendeleti Közlöny”-höz a Magyar Királyi Honvédség számára, I. évf. (1917) 33.sz. 183.p.

263 224/1917. (VIII. 9.) HM.r. a Határrendőrséghez beosztott legénység készültségi pótdíj kezdete.

Kisközlöny a „Rendeleti Közlöny”-höz a Magyar Királyi Honvédség számára, I.évf. (1917) 21.sz. 123.p.

477 372/1917. (XII. 21.) HM.r. a hadmüveleti területek határainak szabályozása, a délnyugati arczvonalparancsnokság körletében való utazásokra vonatkozólag.

Kisközlöny a „Rendeleti Közlöny”-höz a Magyar Királyi Honvédség számára, I.évf. (1917) 28.sz. 469.p.

2 200/1918. (III.13.) ME.r. a hadműveleti és megszállott területekre vonatkozó utazási szabályok tárgyában kiadott 3.000/1917. (I. 30.) B.M.eln.sz. körrendelet módosításáról.

Magyarországi Rendeletek Tára, LI.évf. (1918) 165-168.p.

5 211/1918. (XI. 11.) ME.r. értékek Magyarország területéről való kivitelének eltiltásáról.

Magyarországi Rendeletek Tára, LI.évf. (1918) 2246-2247.p.

22 649/1918. (IX. 17.) HM.r. katonai személyek szabadságolása Oroszországba és Ukrajnába.

Kisközlöny a „Rendeleti Közlöny”-höz a Magyar Királyi Honvédség számára, II.évf. (1918) 86.sz. 566.p.

556/1919. (II. 2.) ME.r. az útlevélkötelezettség elrendeléséről szóló 285/1915. (I.12.) M.E. szám alatt kiadott rendelet módosításáról. Magyarországi Rendeletek Tára, LII.évf. (1919) 195-241.p.

6 000/1919. (II. 17.) PM-BM-IM.ut. az adótól való menekülés meggátlásáról szóló 1919/II. néptörvény és az ennek némely rendelkezését módosító 1919/XVI. néptörvény végrehajtásáról.

Magyarországi Rendeletek Tára, LII. évf. (1919) 195-242.p.

19 790/1919. (II. 12.) BM.kr. az útlevélkötelezettség elrendeléséről szóló 285/1915. (I. 12.) M.E. szám alatt kiadott rendelet módosítása folytán szükséges intézkedésekröl.

Magyarországi Rendeletek Tára, LII.évf. (1919) 317-319.p.

32 129/1919. (III. 5.) BM.kr. az útlevélkötelezettségnek Horvát-Szlavonországok területére és Fiuméra vonatkozó elrendeléséröl.

Magyarországi Rendeletek Tára, LII.évf. (1919) 350-352.p.

72 262/1919. (VIII. 8.) BM.kr. a külföldre szóló útlevelek kiállításáról. Magyarországi Rendeletek Tára, LII.évf. (1919) 1004.p.

7 862/1920. (V. 12.) BM.r. az ország határát ki és befelé átlépőkről való kimutatások vezetése és az ezzel kapcsolatos egyéb intézkedések. Belügyi Közlöny, XXV.évf. (1920) 21.sz. 692-695.p. 


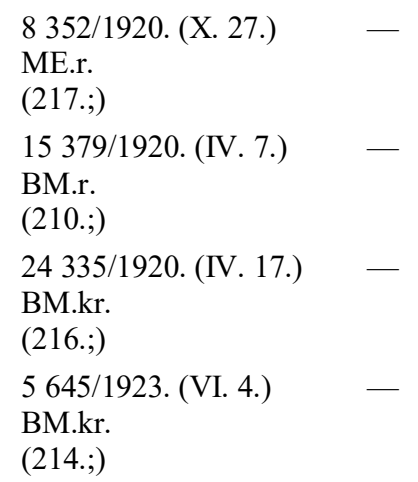

8 352/1920. (X. 27.) ME.r. a megszállott területekről beutazók ellenőrzése. Belügyi Közlöny, XXV.évf. (1920) 48.sz. 1852-1853.p.

15 379/1920. (IV. 7.) BM.r. idegen állampolgároknak, illetőleg idegen útlevelek tulajdonosainak bebocsátása Magyarország területére.

Belügyi Közlöny, XXV.évf. (1920) 16.sz. 578.p.

24 335/1920. (IV. 17.) BM.kr. megszállott magyar területekre való utazások engedélyezése iránt előterjesztett kérelmek elintézésénél követendő eljárás.

Belügyi Közlöny, XXV.évf. (1920) 18.sz. 610-611.p.

5 645/1923. (VI. 4.) BM.kr. a határátlépő állomások kijelölése és az ott szervezett $\mathrm{m}$. kir. állami rendőrségi kirendeltségek hatásköre. Belügyi Közlöny, XXVIII.évf. (1923) 1114-1118.p. 
Mellékletek:

I.sz. melléklet.

Határkapuk a magyar-román és a magyar szerb határon.

II. sz. melléklet

Magyar légtér tilalmi zónája 1914. VII. 20-tól a hadműveletek megindulásáig.

III. sz. melléklet

Az Osztrák-Magyar Monarchiával szemben hadviselő országok állampolgárai meghatározott csoportjainak engedélyezett hazautazása Magyarországról.

IV. sz. melléklet

Változások a polgári lakosság külföldre utazásának módjaiban, a vasút és a Balkánvonat.

V. sz. melléklet

Utazási engedély a Balkánvonaton történő utazáshoz.

VI.sz. melléklet

Európa hadban álló és semleges államai, valamint a megszállt területek és frontvonalak 1915. novemberének végén.

VII. sz. melléklet

A külső hadműveleti területek határvonalának átlépésére jogosító engedélyek Svájcba történő utazáshoz, 1917. augusztusából illetve 1918. januárjából.

VIII. sz. melléklet

Az Osztrák-Magyar Monarchiának semleges államok felé határátlépésre kijelölt határátkelőhelyei, 1918. augusztusától.

Határkapuk a magyar-román és a magyar szerb határon.

I.sz. melléklet.

1903-1914 között határátkelöhelyek:

Román határon Bukovinától a Dunáig: (= után a mai román név)

Csík megye

1. Gyergyótölgyes=Tulgheş (Borszék és Tîrgu Neamţ közt, Tölgyes szoros) 1903-14

2. Gyergyóbékás=Bicazu Ardelean (Gyergyószentmiklós és Piatra Neamţ közt, Békás-szoros) 1903-14

3. Gyimesbükk=Csíkgyimes=Ghimes-Făget (Csíkszereda és Bacău közt; Gyimes szoros, a Tatros folyónál) 1903-14

4. Pricskető (Csíkszépvíz=Frumoasa része, ami a határtól távol van; a hozzá tartozó Pricskető a határon, Gyimesbükk és Úzvölgy közt félúton található) 1904-14

5. Úzvölgy=Valea Uzului (Csíkszereda és Comăneşti közt) (1909-től Csíkszentmárton/Kökert néven; Cs.szentm. távol esik a határtól, de a hozzá tartozó Kőkert település az Úz folyó partján közvetlenül a határon van) 1903-14

Háromszék megye:

6. Sósmezö=Poiana Sărată (Ojtozi sz., Kézdivásárhely és Oneşti közt) 1903-14

7. Mikestelep (Gelence=Ghelinţa része) néven is, (Gelence Kézdivásárhely és Kovászna közt van, az átkelöpont pedig ott, ahol a Putna folyó elhagyja a határt) 1904-14

8. 8. Gór (Gyulafalva=Kommandó=Comandău külterülete; Papolcz része), Papolcz=Păpăuţi. Az átkelő a Fekete-halom csúcsától (kb. 1630 m magas) É-ra, a Gór-patak mellett található

9. Musatelep=Muşa, (Papolcz=Păpăuţi része), az átkelő a Kis-Baszka (Bisca Mica) folyó áttörésénél található, a Csihányos hegycsúcstól (1602-1605 m magas) K-re 1903-14

10. Karajos (Zágon része, de korábban vsz. Papolczhoz tartozott), máskor Gyulafalva-telep néven is említve. A NagyBaszka folyó (Bisca Mare) áttörésénél, a Nagy-Bóta és a Hosszúhavas közt

11. Bodzakraszna=Crasna (Bodza folyó áttörésénél, Bodzaforduló és Buzău közt) 1903-14

Brassó megye:

12. Ósánc (Hosszúfalu=Săcele része) (Brassó és Vălenii de Munte közt) 1903-14

13. Predeál=Predeal (Brassó és Ploieşti közt a Tömösi szorosban) 1903-14

Fogaras megye:

14. Simon=Şimon; (néha Guczán=? néven is) Törcsvár város és Sinaia közt, 1903-14

15. Törcsvár=Bran (Brassó és Cîmpulung közt a Törcsvári szorosban), 1903-14

16. Breáza=Breaza (Fogaras és a Moldoveanu közt; az átkelő a Fogarasi havasok közepén lépi át a határt), 1903-14

Szeben megye:

17. Verestorony=Turnu Rosu; néha Bojca=Boiţa néven (Nagyszeben és Rîmnicu Vîlcea közt), 1903-14

18. Zsinna=Jina (Szászsebes és Craiova közt; Zsinna a határtől távolabb helyezkedik el, de az utolsó lakott hely; az átkelő a Szebeni-hg.-ben a Piatra Alba csúcstól Ny-ra van), 1903-14 
Hunyad megye:

19. Csimpa=Cîmpa, néha Petrilla=Petrila néven; az átkelőhely útja Petrillától K-re, a Magyar-Zsil völgyétől kissé D-re metszi a határt 1909-14

20. Szurduk, Kimpényszurduk: a Zsil völgye (Petrozsény és Tîrgu Jiu közt = Szurduk hágó) 1903-14

21. Vulkán hágó (Zsilyvajdejvulkántól D-re), 1903-14

Krassó-Szörény megye:

22. Orsova=Orşova (Duna mellett, Lugos és Turnu Severin közt), 1903-14

Szerb határon Romániától Boszniáig: (= után a mai román vagy szerb név)

Krassó-Szörény megye:

1. Orsova=Orşova 1903-10, 1913-14

2. Szvinica=Svinița (Majdanpek közelében, Duna kanyarnál) Csucsobka=? 1903-10

3. Berszászka $=$ Berzasca, időnként Drenkova $=$ Drencova néven is $1909-10$

4. Ómoldova=Moldova Veche 1907-10

5. Belobreszka $=$ Fejérdomb $=$ Belobreşca 1907-10

6. Báziás=Baziaş* 1907-10

Temes megye

7. Palánk=Banatska Palanka (a Néra torkolata) 1903-10

8. Temessziget=Ostrovo (a Duna szigetének Ny.-i felén) 1903-10

9. Temeskubin=Kevevára=Kovin (Morava torkolattal szemben) 1903-10, 1913-14

Torontál megye:

10. Homolicz $=$ Omlód $=$ Omoljica (Pancsovától D-re) 1903-10

11. Pancsova=Pančevo (Belgrádtól K-re) 1903-10, 1913-14

Szerém megye:

12. Zimony=Zemun (Belgrád elővárosa) 1903-10, 1913-14

13. Kupinovo=Kupinovo (Bg.-tól Ny-ra, legközelebb Skela-val szemben) 1913-14?

14. Klenak=Klenak (Bg.-tól Ny-ra, Šabac-cal szemben) 1913-14?

15. Mitrovica=Sremska Mitrovica (Bg.-tól Ny.-ra, legtávolabb) 1913-14?

A 13-15 közti átkelők a horvát-szerb határon voltak; lehetséges (sőt, valószínü), hogy 1910 elött is működtek, csak a magyarszerb átkelők közt nem tüntették fel öket

Kivándorlók részére: 1. Fiume 1904-14, 2. Csaca 1911-14, 3. Pozsony 1911-14, 4. Királyhida 1911-14, 5. Sopron 1911-14,

6. Csáktornya 1911-14, 7. Gyékényes 1911-14, 8. Gombos 1911-14, 9. Újvidék 1911-14, 10. Pancsova 1911-14

Forrás ! PARÁDI József: Rendőrség a határőrizetben. 255.p. Budapest, 2003, Tipico Design. 266 p. HU-ISBN 9637623329. /Rendvédelem a határokon a XIX-XX. században, 3./ HU-ISSN - 

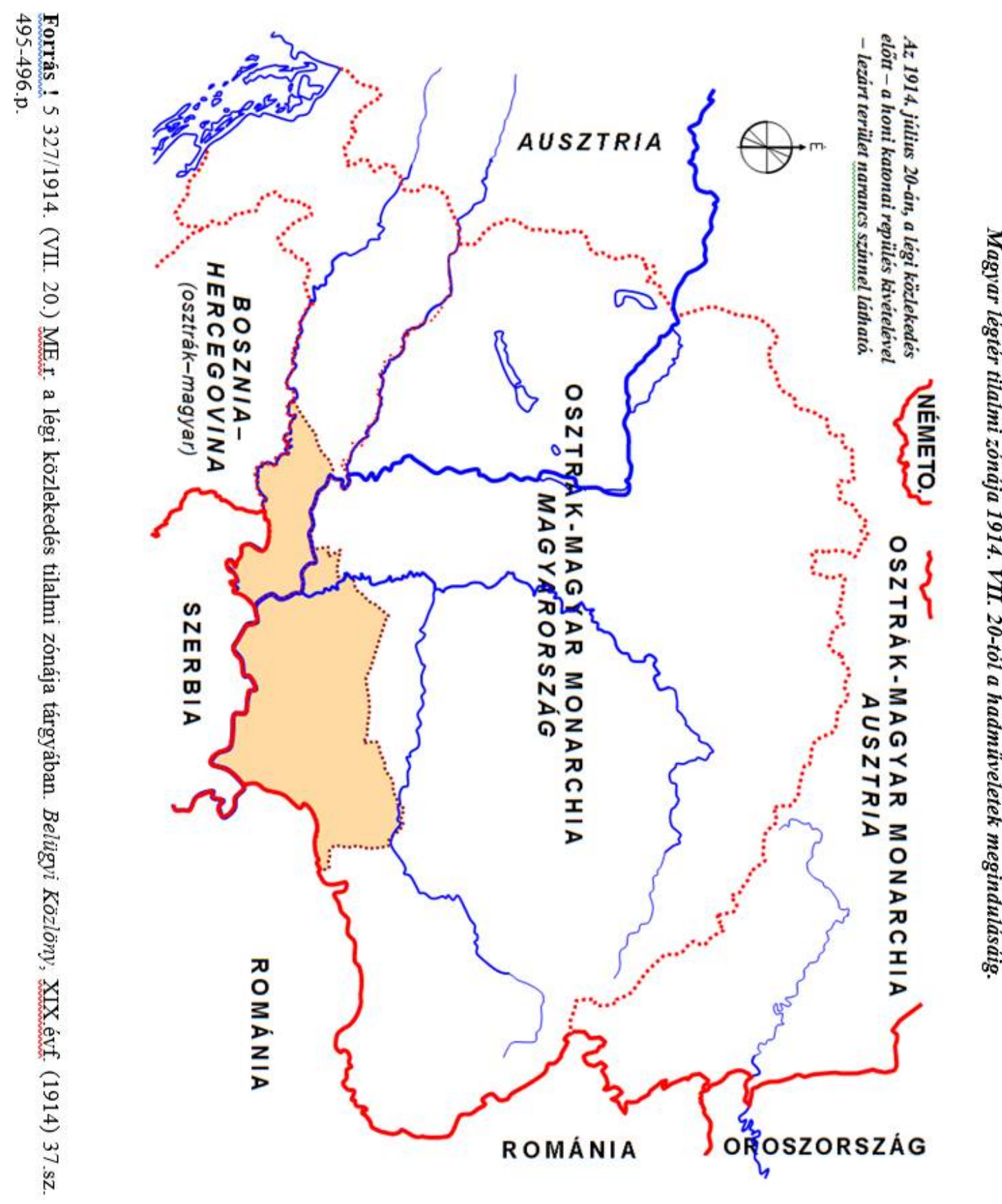

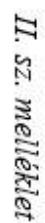




\section{Az Osztrák-Magyar Monarchiával szemben hadviselö országok állampolgárai meghatározott csoportjainak engedélyezett hazautazása Magyarországról}

\begin{tabular}{|c|c|c|c|}
\hline állampolg. & időszak & útvonal & megjegyzés \\
\hline brit & nincs adat (1915.) & nincs adat & \\
\hline francia & nincs adat (1915.) & nincs adat & \\
\hline szerb & 1915. május és június & $\begin{array}{l}\text { Magyarország-Verestorony ha- } \\
\text { tárátkelőhely-Románia-Szerbia }\end{array}$ & $\begin{array}{l}\text { az egyénileg utazók részére külön igazol- } \\
\text { vány is kiállításra került, külön megjelöl- } \\
\text { ve a kilépésre kijelölt határátkelöhelyet }\end{array}$ \\
\hline olasz & $\begin{array}{l}\text { 1915. július, majd } \\
\text { 1916. április }\end{array}$ & $\begin{array}{l}\text { Magyarország-Ausztria-Svájc- } \\
\text { Olaszország }\end{array}$ & \\
\hline orosz & $\begin{array}{l}\text { 1915. augusztus, majd } \\
\text { 1917. október }\end{array}$ & $\begin{array}{l}\text { nincs adat, de } 1915 \text {-ben feltehe- } \\
\text { tően Gyimesbükk vagy Predeál } \\
\text { határátkelőhelyen és Románián } \\
\text { át történt }\end{array}$ & \\
\hline amerikai & 1917. május-június (4 hét) & Magyarország-Ausztria-Svájc & $\begin{array}{l}\text { az egyénileg utazók részére arcképes iga- } \\
\text { zolvány is kiállításra került; a hadüzenet } \\
\text { majd csak 1917. december 7-én kelt }\end{array}$ \\
\hline kínai & 1917. november & Magyarország-Ausztria-Svájc & \\
\hline román & 1918. január & nincs adat (közös viszonylat) & \\
\hline
\end{tabular}

Forrás ! 14 139/1915. BM. kr. Magyarországon internált szerb és Szerbiában internált magyar állampolgárok egy részének hazabocsátásáról. ; 18.711/1915. BM. kr. az olasz állampolgárok egy részének hazabocsátásáról. ; 24.550/1915. BM. kr. az orosz állampolgárok egy részének hazabocsátásáról. ; 9.051/1916. BM. kr. az olasz állampolgárok egy részének hazabocsátásáról. ; 1.551/1917. BM. kr. az orosz állampolgárok egy részének hazabocsátásáról. ; 489/1917. BM. kr. kinai állampolgárokkal szemben követendő eljárásról.

Változások a polgári lakosság küllföldre utazásának módjaiban, a vasút és a Balkánvonat.

A háború kitörése - mint az a szerbiai határforgalom megszünéséböl és az életbe lépett vízumkényszerek alapján láthatóvá vált - azonnal véget vetett az Európát átszelő Orient Expressz járatainak, de a Szerbiába tartó, vagy azon áthaladó gyorsvonatok is kényszerủ szünetre ítéltettek. A háború első másfél évében Németország illetve Ausztria-Magyarország és Törökország között Románián (Bukaresten) és Bulgárián át közlekedtek a vonatok. Az utasoknak egyszer vagy többször át kellett szállnia a központi hatalmak legtávolabbi fővárosai közötti utazásuk során. A háború alatt továbbra is a vasút volt az egyedüli gyors közlekedési lehetőség a polgári lakosok részére, azonban részükről még számottevő volt - bár a korábbit meg sem közelítette - a közúti forgalom is. Bár ahogy ismertetésre került, a Monarchia lakosai csak engedéllyel utazhattak járműveikkel külföldre.

Szerbiának 1915 végére befejeződött megszállását követően helyreállították a zimonyi vasúti hidat, így ismét volt vonatösszeköttetés Magyarország és Belgrád között. Ezt követően, már 1916 januárjában útjára indult a központi hatalmakat öszszekapcsoló Balkánvonat (németül: Balkanzug) nemzetközi gyorsvonat. A Berlin-Boroszló/Breslau-[német útlevélellenőrzés]-Oderberg [osztrák útlevél-ellenőrzés]-Galánta, a Berlin-Drezda-[német útlevél-ellenőrzés]-Tetschen [osztrák útlevél-ellenőrzés]-Bécs-Galánta, és a München-[német útlevél-ellenőrzés]-Salzburg [osztrák útlevél-ellenőrzés]-BécsGalánta irányából érkező első és másodosztályú kocsikból a magyarországi Galántán állították össze a Balkán-félszigetre tovább induló szerelvényt. Innen útját Galánta-Budapest-Zimony [magyar útlevél-ellenőrzés]-Nándorfehérvár-Jagodina [bolgár útlevél-ellenőrzés]-Szófia-[török útlevél-ellenőrzés]-Konstantinápoly vonalon heti két alkalommal tette meg, s ellenkező irányban is ugyanennyi közlekedett. Ezen vonattal történő utazás az érvényes útlevélen és ,utazási engedély”-en kívül az úti poggyászok mennyiségét és tartalmát meghatározó korlátozásokat is vont magával. A vonat 1918. júniusától már csak heti egy alkalommal közlekedett, majd 1918. X. 15-én a járat megszünt, mivel Bulgária fél hónapja fegyverszünetet kért és kapott az antant hatalmaktól.

Forrás ! - GRANDE, Julian: New „Balkan Express”. The Press, LVI.évf. (1916) 15547.sz. 8.p.

- The „Balkanzug”. Kalgoorlie Western Argus, XXI.évf. (1916) 1916.05.09-i sz. 32.p. 
Utazási engedély a Balkánvonaton történö utazáshoz

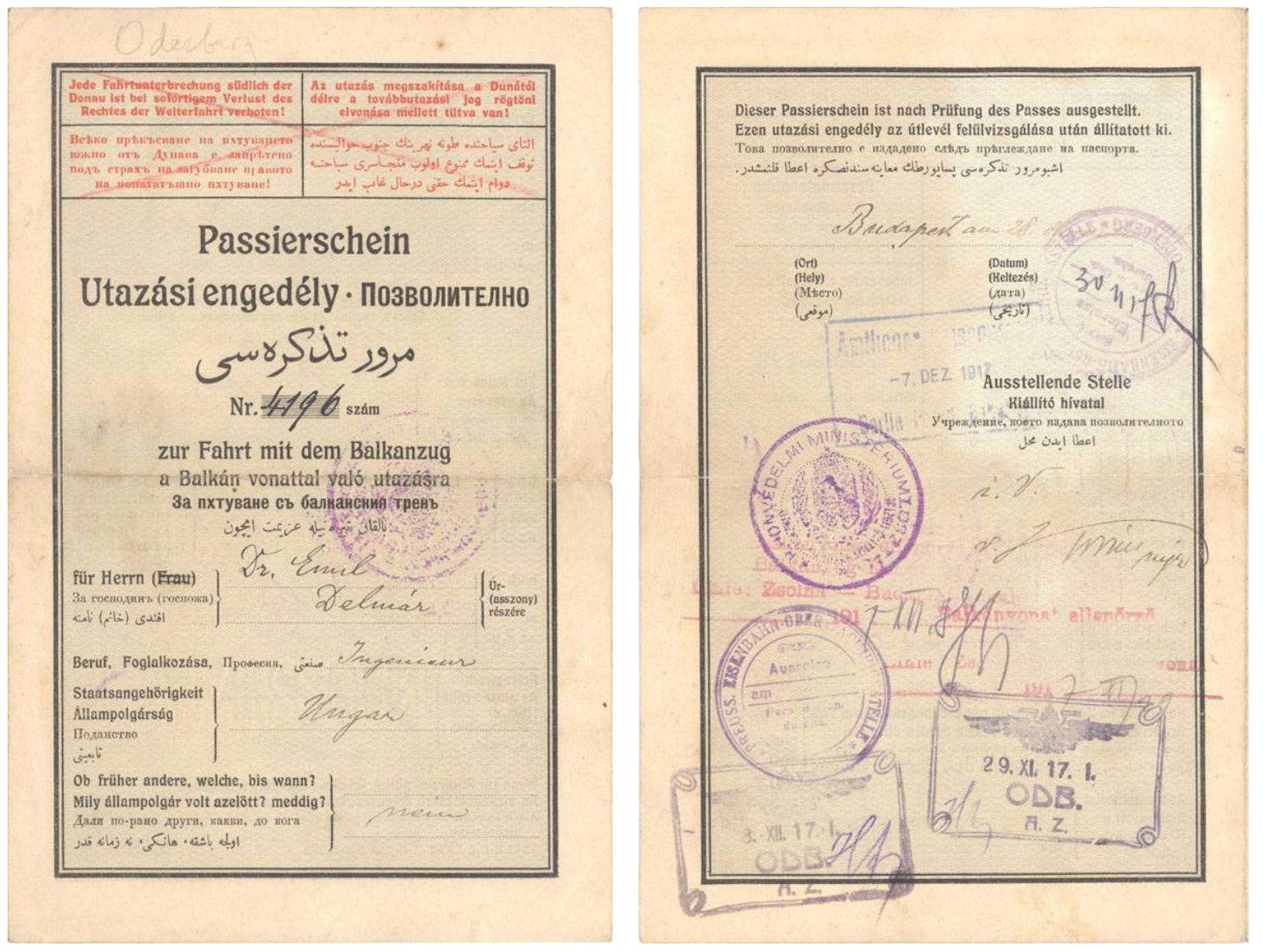

A félbehajtott lap elö- és hátoldala. Utóbbi a határátlépések bélyegzéseivel; az okmánnyal a tulajdonosa 1917. végén Budapestről Berlinbe és vissza utazott. (Az engedély másik fajtáján nincs az előoldali okmánymegnevezés feletti figyelmeztetés.)
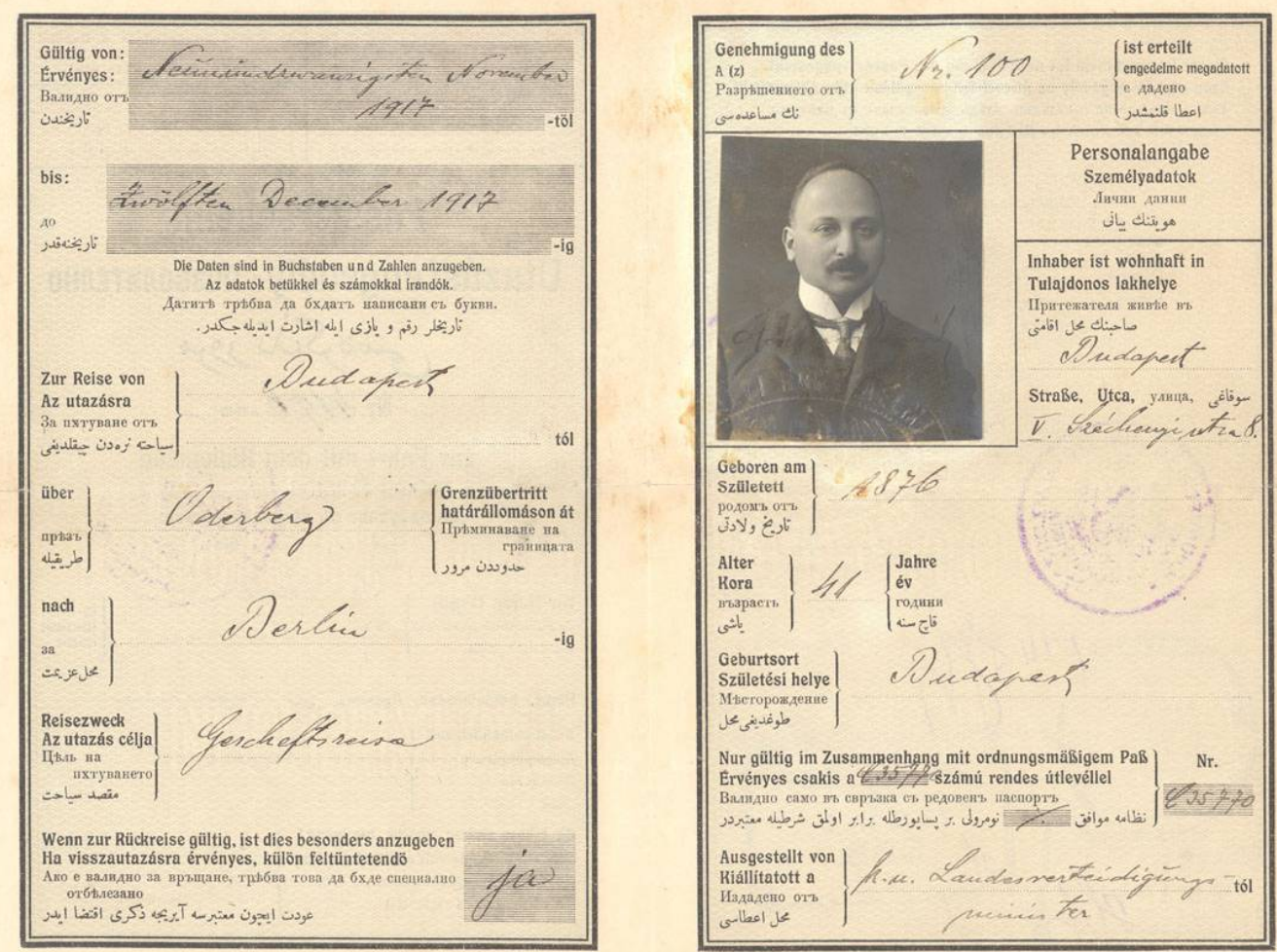

Az okmány belső oldalai, az útvonal és érvényesség ismertetésével, a jogosult adataival és fényképével.

ForRás ! Som Krisztián magángyüjteménye. 


\section{Európa hadban álló és semleges államai, valamint a megszállt}

VI. sz. melléklet terïletek és frontvonalak 1915. novemberének végén.

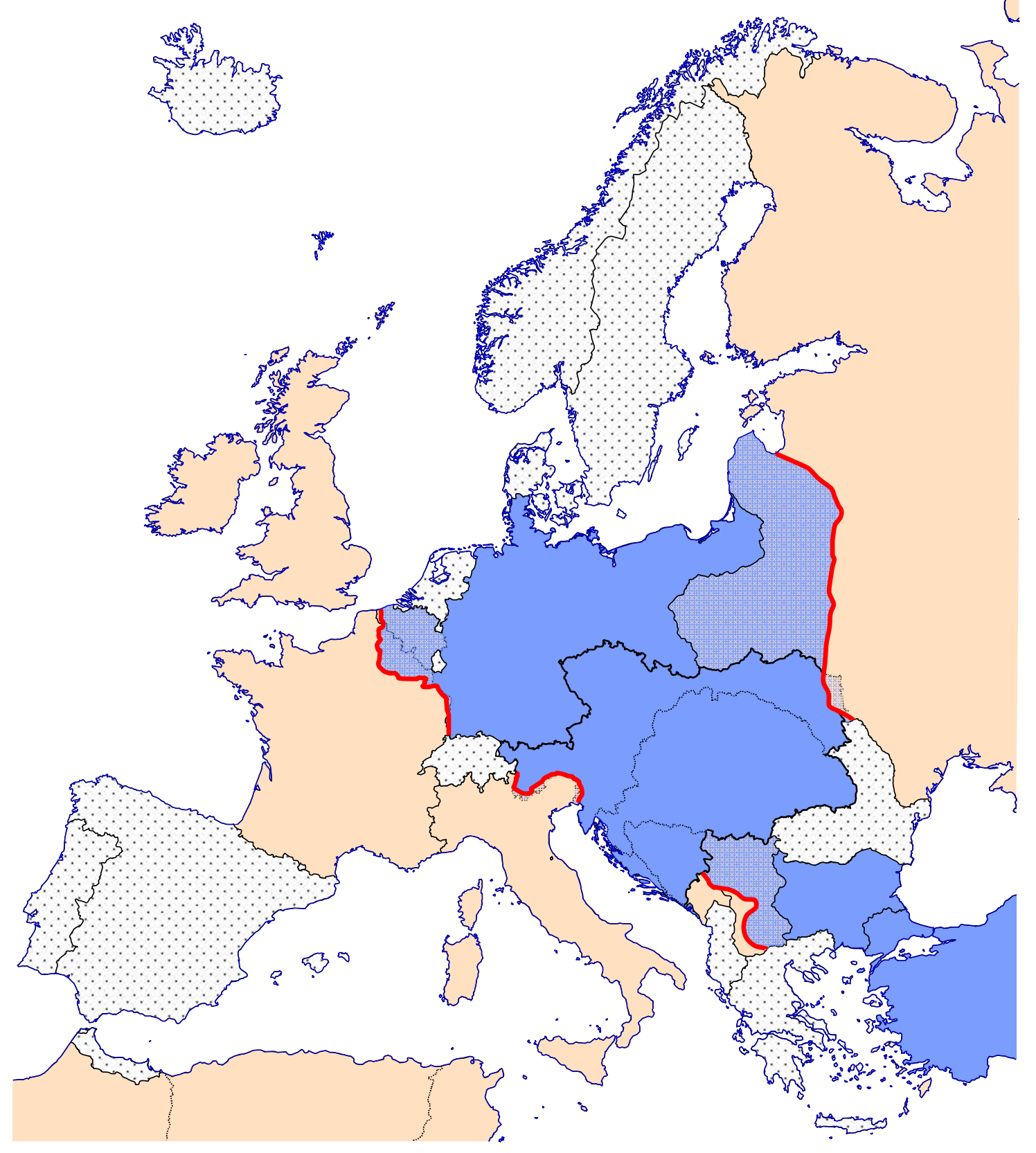

Kék (sötét) színnel a központi hatalmak, barna (világos) színnel az antant hatalmak és azok szövetségesei láthatóak; a semleges államok pontozott fehér mezővel kerültek ábrázolásra. Az 1915. november végi front állása vastag vonallal került jelölésre. 
A külsö hadmüveleti területek határvonalának átlépésére jogosító engedélyek

VII. sz. melléklet Svájcba történö utazáshoz, 1917. augusztusából illetve 1918. januárjából

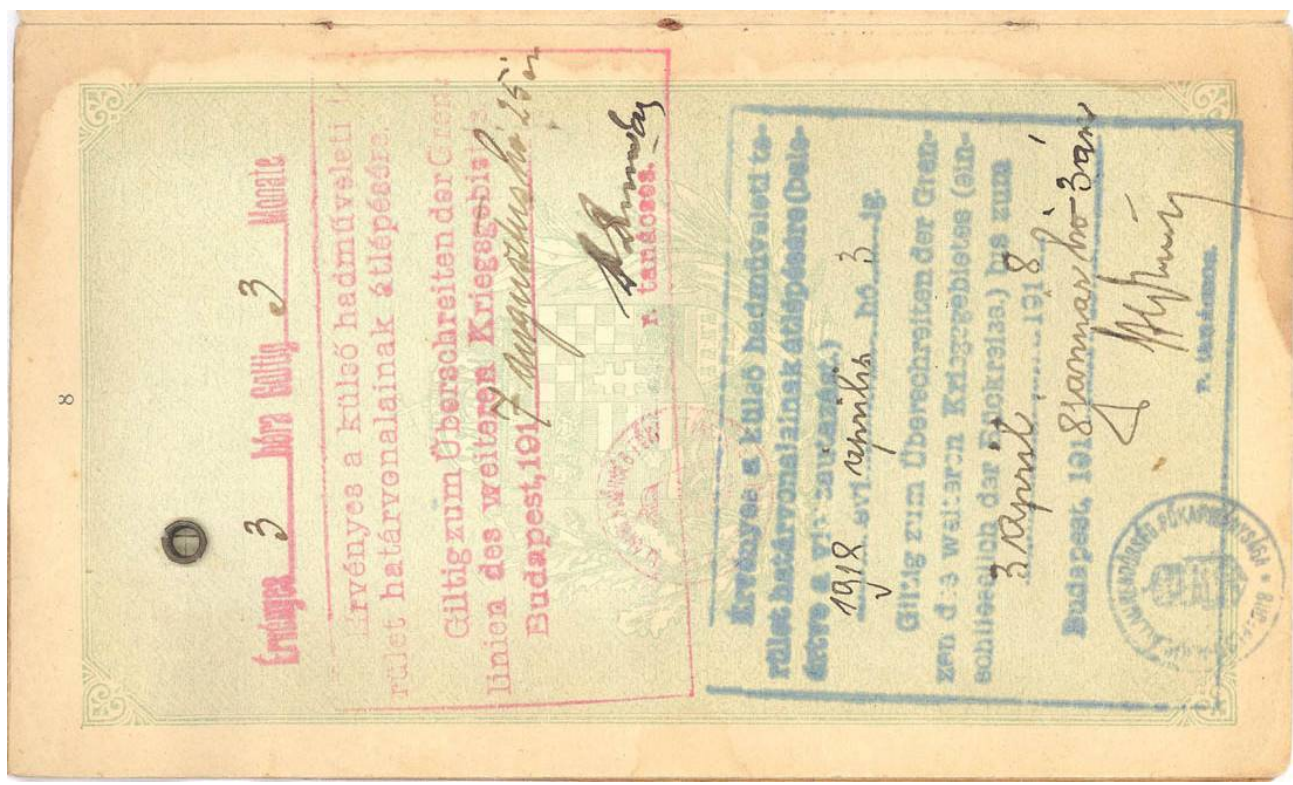

Magyar útlevél lapján, a jobboldali (a valóságban az alsó) lenyomat kiemeli, hogy a visszautazásra is érvényes az engedély.

ForRás ! Som Krisztián magángyüjteménye

VIII. sz. melléklet

Az Osztrák-Magyar Monarchiának semleges államok felé határátlépésre kijelölt határátkelöhelyei, 1918. augusztusától.

\begin{tabular}{|l:l|}
\hline \multicolumn{1}{|c|}{ úti cél } & határátlépésre engedélyezett átkelöhely \\
\hline Svájc & Feldkirch (Liechtensteinen át) \\
\hline Hollandia & Elten \\
\hline Dánia & Sassnitz \\
\hline Norvégia & Sassnitz \\
\hline Svédország & Sassnitz \\
\hline Oroszország & egyéb \\
\hline Ukrajna & egyéb \\
\hline
\end{tabular}

